\title{
ORCHIDS IN THE ERA OF GRIGORY VON LANGSDORFF: TWO GOLDEN DECADES IN THE HISTORY OF THE BOTANICAL EXPLORATION OF BRAZIL (1813-1830)
}

\author{
Carlos Ossenbach
}

\author{
Orquideario 25 de Mayo, San José, Costa Rica - caossenb@racsa.co.cr \\ Jardín Botánico Lankester - Universidad de Costa Rica
}

\begin{abstract}
The figure of Grigory Ivanovich von Langsdorff was largely neglected by the scientific literature of the 19th and 20th centuries. German-born von Langsdorff was consul of the Russian Empire in Rio de Janeiro. His activities in Brazil from 1813 to 1830 are here described, a time during which his house in Rio and his famous fazenda Mandiocca became the center of scientific activity and the point of attraction for European travellers and naturalists who flocked to Brazil after its frontiers were opened to foreigners in 1808 by King Joâo VI of Portugal. Wilhelm Freyreiss, Friedrich Sellow, Maximilian zu Wied-Neuwied, Augustin de SaintHilaire, Carl Friedrich Philipp von Martius, Johann Baptist von Spix, Giuseppe Raddi, Johann Baptist Emanuel Pohl, and Ludwig Riedel are among those who explored Brazil impulsed by von Langsdorff and often under his patronage. Their journeys in Brazil culminated in von Langsdorff's ill-fated expedition to the interior of Brazil between 1822 and 1829, while the epilogue is marked by Langsdorff's return to Germany, in a state of insanity and no longer able to publish the results of his life-long scientific efforts.
\end{abstract}

KEY wORDS: botanical history, Brazil, exploración, exploration, historia de la botánica, orchids, orquídeas

After the Portuguese court moved to Rio de Janeiro in 1808, and Brazil opened its ports after centuries of isolation, the country became an El Dorado for European travellers and naturalists, especially since it would take until 1825 for the Spanish colonies to gain their independence and open their borders to foreigners.

Brazil's immense territory -8.5 million square kilometers - was, with exception of part of its coast, at that time mostly unexplored. This offered outstanding opportunities for the many scientists and adventurers who soon arrived. That an important number of them were Germans was largely a consequence of the impulse given to the scientific exploration of Brazil by a German-born naturalist, the Baron von Langsdorff, who had first set foot in Brazil in 1803, and afterwards made his home there from 1813 to 1830 .

At the same time, the marriage of Dom Pedro, the eldest son of King Joâo VI of Portugal, to Princess Maria Leopoldina of Austria in 1817, brought further notable scientists who travelled to Brazil under her patronage, namely the Italian Giuseppe Raddi, the Austrian Johann Pohl, and the Germans von Martius and von Spix.
Georg Heinrich von Langsdorff. Better known by his Russian names, Grigory Ivanovich, Baron von Langsdorff (1774 -1852) (Fig. 1) was a GermanRussian naturalist and explorer as well as a Russian diplomat. A member and correspondent of the Russian Imperial Academy of Sciences and a respected physician, Langsdorff graduated in medicine and natural history from the German University of Göttingen.

In the first decade of the $19^{\text {th }}$ century, Langsdorff had already gained considerable experience as an explorer. He had become a Russian citizen and participated as naturalist and physician in the Russian scientific circumnavigation expedition of 1803 to 1805 , under the command of Ivan Fedorovich Kruzenstern. The expedition sailed across the Atlantic spending several months (1803-1804) in the southern Brazilian state of Santa Catarina, before continuing around Cape Horn and into the Pacific. This was Langsdorff's first contact with tropical America. He left the expedition when it arrived at the peninsula of Kamchatka and set off to explore the Aleutian, Kodiak and Sitka islands. He then sailed from San 


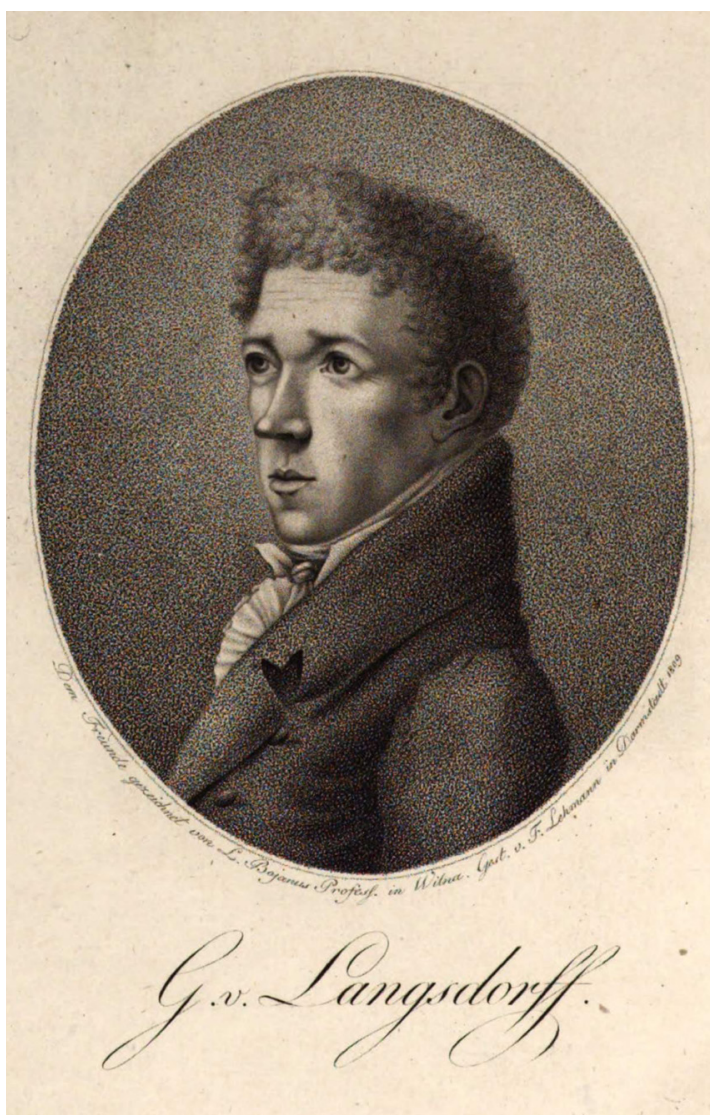

Figure 1. Grigory Ivanovich Langsdorff, Baron von Langsdorff (1774.1852) in 1809. Engraved by F. Lehmann from a drawing by L. Bojanus.

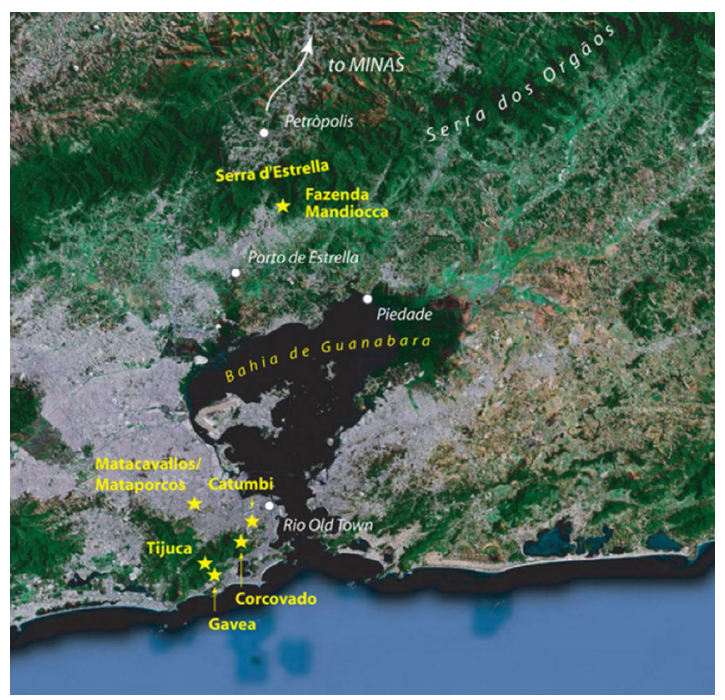

Figure 2. Location of Langdorff's Fazenda Mandiocca. In Baldini \& Guglielmone, 2012: 6.
Francisco to Siberia and travelled overland to Saint Petersburg, arriving in 1808 .

After being nominated consul general of the Russian Empire in Brazil, Langsdorff arrived in Rio de Janeiro in 1813. He would live in Brazil until 1830. His house soon became the center of scientific activity in and around Rio de Janeiro. Langsdorff hosted and entertained, and quite often sponsored, foreign naturalists and scientists. Among them were such prestigious names as Georg Wilhelm Freyreiss (who had travelled to Rio employed as his "aidenaturaliste"), Friedrich Sellow, Prince Maximilian Alexander Philipp zu Wied-Neuwied, William Swainson, Augustin Saint-Hilaire, Frei Leandro de Sacramento (who named the new genus Langsdorfia in the Rutaceae in the baron's honor), Ludwig Riedel, and Maria Graham Callcott.

In 1816 Langsdorff acquired his famous country retreat, Fazenda Mandiocca, in the vicinity of Porto Estrela (today part of the municipality of Magé, Rio de Janeiro) (Fig. 2). Here he developed a farm and turned his house and property into a cultural and scientific nucleus by creating a museum of natural history, a botanical garden and a vast library. According to Kommisarov, one of Langsdorff's biographers, Mandiocca "had a large main house, other houses which were let to travellers, many other dependencies, a coffee plantation with some 30-40,000 plants, and hundreds of slaves, giving the impression of a typical Brasilian fazenda of its days. The marvellous botanical garden, a library containing selected works in all fields of science and its multiple scientific collections made of Mandiocca the scientific center of Rio de Janeiro, a place frequently visited by foreign travellers. There one could find representatives of the intellectuality of the capital, intermingled with local artists and Russian seamen. It was, undoubtedly, the center of culture of Brazil in the old days" (Kommisarov 1994).

On more than one occasion, the fazenda received a Royal visit from Dom Pedro and Dona Maria Leopoldina. It is said that it was Langsdorff's enthusiastic collaboration with the scientific interests of the Austrian Archduchess that laid the foundations for many of the natural history expeditions of their time, including those of Carl Friedrich Philipp von Martius, Johann Baptist von Spix, Giuseppe Raddi, 
and Johann Baptist Emanuel Pohl. These expeditions produced some brilliant results, such as von Martius' Flora Brasiliensis, published between 1840 and 1906. Langsdorff himself undertook numerous excursions around Rio de Janeiro and, more importantly, in the Province of Minas Gerais during the years between 1813 and 1821, sending many of his botanical and zoological collections to Saint Petersburg. He was untiring, absolutely indifferent to all difficulties and expected the same from all others. Saint-Hilaire, who collected with him during this period, although a much younger man, complained about not being able to keep up with Langsdorff's pace.

A much larger portion of Brazil's immense territory was explored during Langsdorff's time than during the previous three centuries. The scientific results were exceptional, and Langsdorff's role has been, even up to the present, largely underestimated.

Georg Wilhelm Freyreiss. Born in Frankfurt, the son of a shoemaker, Georg Wilhelm Freyreiss (1789-1825) showed an early interest in natural history. This brought him into contact with the respected ornithologist Meyer in Offenbach, who recommended him to Langsdorff in Saint Petersburg. Freyreiss travelled to Russia, and in 1812 left with von Langsdorff for Rio de Janeiro. However, due to stormy weather the journey was interrupted, and they were obliged to winter in Sweden. Freyreiss took advantage of the opportunity to visit Stockholm and Uppsala, where he made the acquaintance of the eminent botanists Olof Peter Swartz and Carl Peter Thunberg, who furnished Freyreiss with letters of recommendation to Lorentz Westin, the Swedish Consul in Rio. Once in Rio, Freyreiss soon had personal differences with Langsdorff. This led him to take a position with Westin, representing the interests of the Royal Academy of Sciences in Stockholm in collecting material for the herbaria of Stockholm and Uppsala. In July 1814 Freyreiss went to Minas Gerais, taking part in a trip organized by Baron Wilhelm von Eschwege, then director of the mining companies of Brazil and one of the most learned students of Brazilian natural resources (Rodrigues de Moraes, 2014: 123). Freyreiss made large collections of birds, insects and plants, sending many of them to the Swedish Academy, which published most of his travel reports and named him a foreign correspondent in 1816.

Recommended by State Minister Araujo Conde de Barca, Freyreiss was named King's Naturalist with a lifelong salary of 1,000 Crusados and appointed Professor of Zoology at the University of Rio de Janeiro.

Following this, Freyreiss became attached to the explorations of Prince Maximilian Wied-Neuwied and the German botanist Friedrich Sellow (1815-1817). He separated from the Prince's expedition on several occasions, rejoining it again further ahead. Freyreiss collected thousands of specimens of plants and bird skins for the Botanical and Zoological Museums in Berlin. Finally, in 1818, Freyreiss was given permission to settle in Bahia and to establish a German colony, which he named Leopoldina in honor of the Brazilian Princess. In 1824 Freyreiss published an account of life in Brazil, Beitrage zur näheren Kenntniss des Kaiserthums Brasilien (= Contributions to a closer knowledge of the Empire of Brazil). An account of his travels, Reisen in Brasilien (= Travels in Brazil), was published nearly 150 years afterwards in 1968. Both works are largely of anthropological interest. He died in 1825 in the colony he had founded.

Only a few specimens of Orchidaceae are known among Freyreiss' collections, all collected during his expedition to Minas Gerais, and described as new to science by Swedish botanist Carl Peter Thunberg in his Plantarum Brasiliensum (1817-1821). These are Cattleya crispata (Thunb.) Van den Berg (Fig. 3), Epidendrum dendrobioides Thunb. (Fig. 4) and Zygopetalum pedicellatum (Thunb.) Garay.

Friedrich Sellow. Born in Potsdam to Carl Julius Samuel Sello, the Royal Gardener at Sanssouci, Friedrich Sellow (he changed later his family name adding a "w") (1789-1831) was apprenticed to Carl Ludwig Willdenow before studying botany in Paris and London. With recommendations and financial support from Alexander von Humboldt, he travelled to the Netherlands and England in 1811, where he made the acquaintance of the most prominent botanists of his time.

While in London, he was invited by Baron von Langsdorff to visit Brazil and travelled to Rio de Janeiro, where he arrived in March 1814. As we 


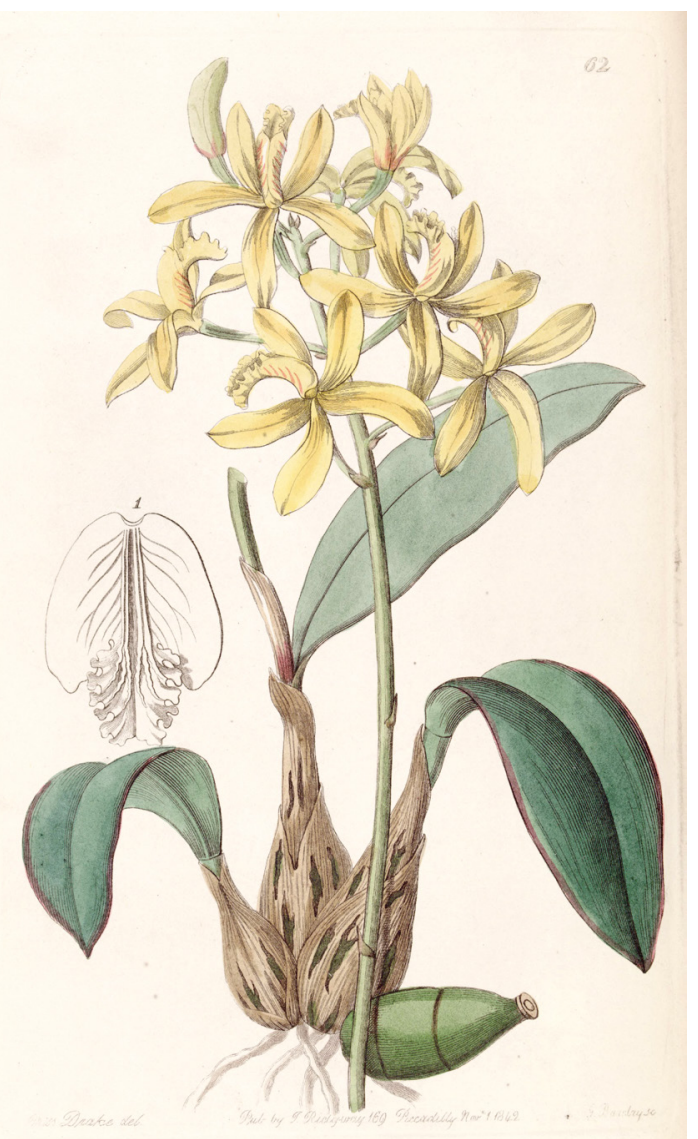

Figure 3. Cattleya crispata (Thunb.) C.Berg, as Sophronitis crispata (Thunb.) C.Berg. \& M.W.Chase, in Edward's Botanical Register n.s. 6, 28: t. 62.

have read, in Langsdorff's house he met Georg W. Freyreiss and some months later, in 1815, Prince Maximilian Alexander Philipp zu Wied-Neuwied. When Prince Maximilian arrived, Freyreiss and Selllow were ready for a journey to the northeastern regions of Brazil, which was to be sponsored by Langsdorff. In return for his investment, Langsdorff would receive the zoological collections for himself. Both Freyreiss and Sellow had letters of recommendation to the authorities of the Brazilian provinces, and they had been appointed as 'financed naturalists', with annual pensions of 400,000 reis (Rodrigues de Moraes, 2009). The two naturalists and the Prince travelled partly together, partly on their own, until finally, early in 1817 , near the Rio Mucuri, they all met again. Arriving in Salvador

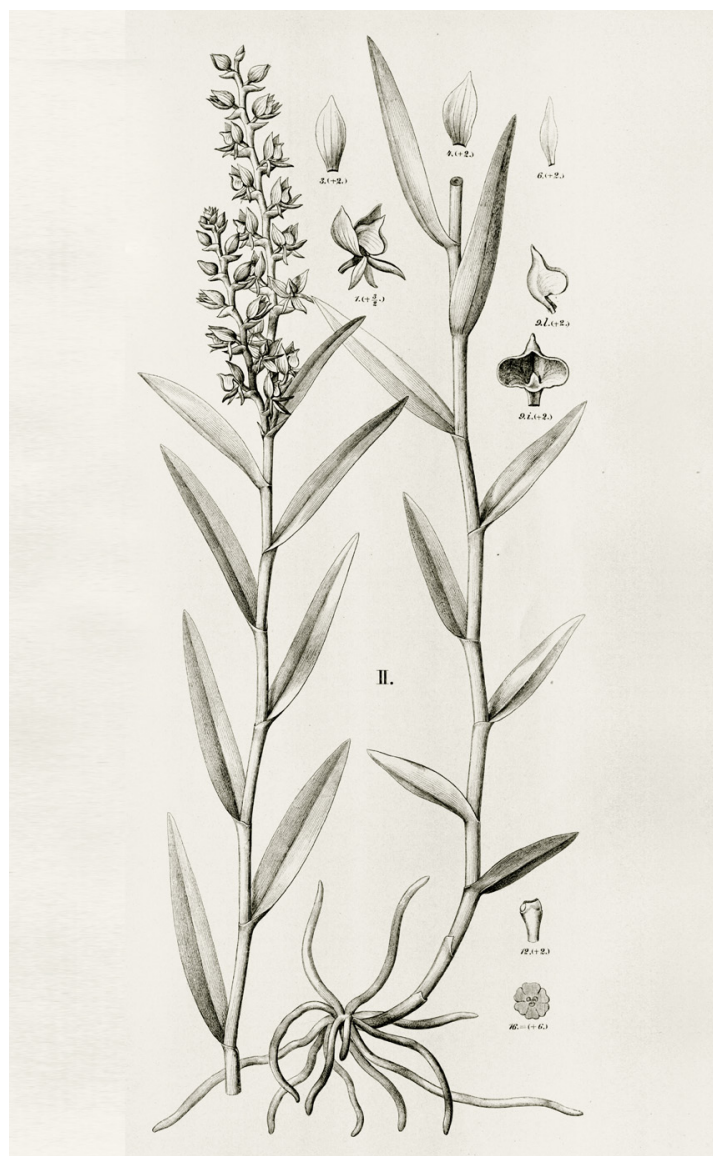

FIgURE 4. Epidendrum dendrobioides Thunb. as synonym Epidendrum carnosum Lindl., in v. Martius, Eichler, \& Urban, 1898-1902, Flora Brasiliensis, vol. 3, part 6: tab. 45.

de Bahia, Prince Maximilian considered that his collections were sufficient and departed for Europe in May of that year.

During the following eleven years, financed by the government of Prussia, Sellow explored southern Brazil and Uruguay, travelling through unexplored regions. He collected over 12,000 plants, 5,000 birds, 110,000 insects and 2,000 samples of stones and minerals, which he sent to scientific institutions in Brazil, Portugal, England and Germany.

Sellow drowned in the Rio Doce in October 1831, aged 42. It is assumed that his canoe crashed into the rocks of the Cachoeira Escura (the 'Dark Waterfall'). Many specimens of Orchidaceae from Sellow's collections can be found in European and American herbaria. The Oakes Ames Herbarium of Harvard 


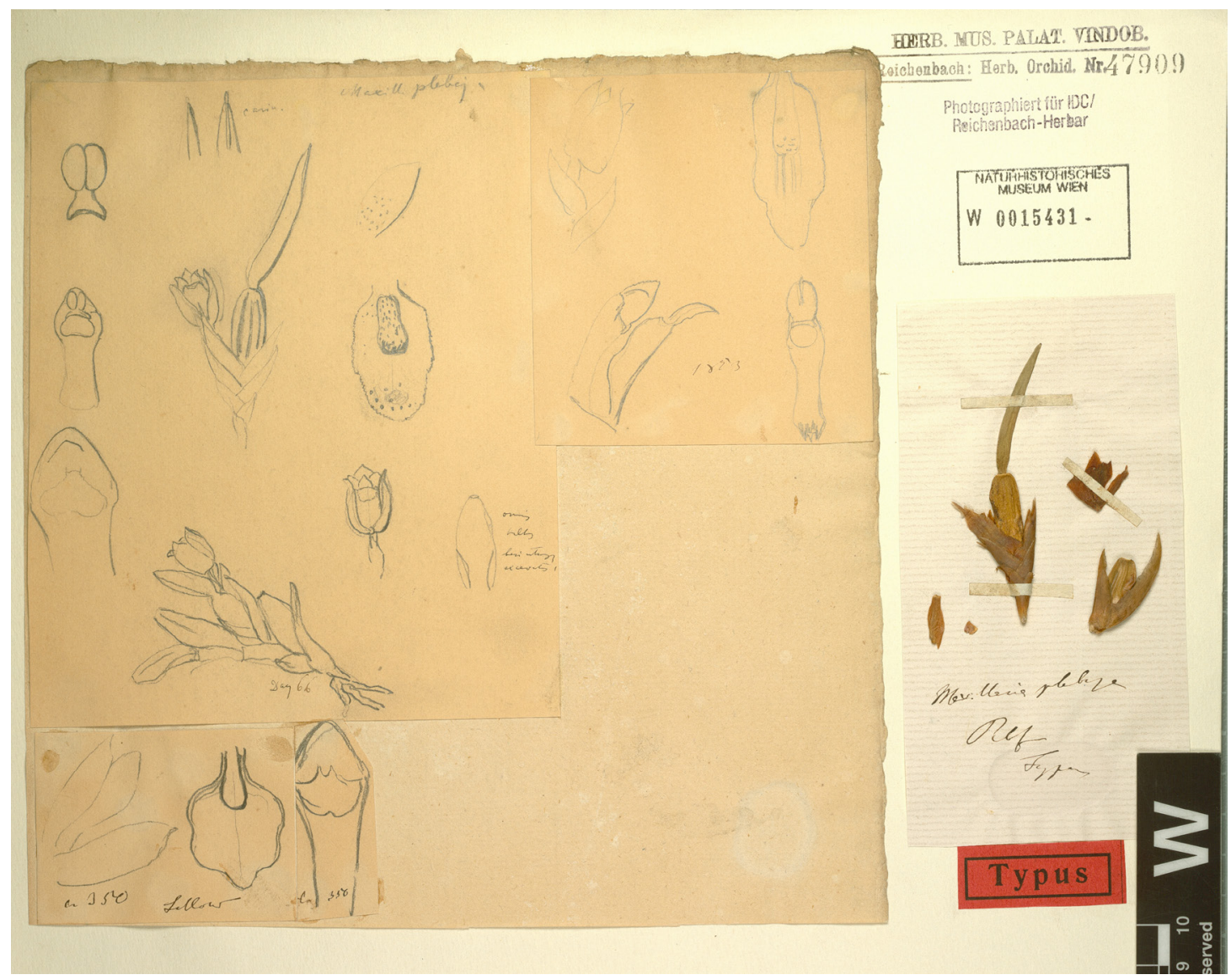

Figure 5. Sketch by Sellow and type specimen of Maxillaria plebeja Rchb. f. at the herbarium of the Vienna Natural History Museum, $\mathrm{N}^{\circ} \mathrm{w} \_15431$.

University holds specimens of Cranichis candida Lindl., Epidendrum carnosum Lindl., Epidendrum dipus Lindl., Epidendrum faustum Rchb.f., Isochilus brasiliensis Schltr., Pleurothallis sonderana Rchb.f., Ponera australis Cogn., and Ponera striata Lindl. At the Vienna Natural History Museum we find Eulophia arundinae Rchb.f., Galeandra beyrichii Rchb.f., Koellensteinia eburnea (Barb. Rodr.) Schltr., Maxillaria cepula Rchb.f., and Maxillaria plebeja Rchb.f. (Fig. 5). The Herbarium of the Botanical Garden at Meise in Belgium has amongst its collections specimens by Sellow of Campylocentrum densiflorum Cogn., Campylocentrum sellowii (Rchb.f.) Rolfe, Notylia stenantha var. angustifolia Cogn., and Oncidium sellowii Cogn. The Royal Botanic Gardens at Kew holds Brassavola tuberculata Hook., Campylocentrum sellowii (Rchb.f.) Rolfe, Cattleya amethystoglossa Linden
\& Rchb.f. ex Warner, Cattleya cinnabarina Beer, Cyanaeorchis arundinae (Rchb.f.) Barb.Rodr., Elleanthus crinipes Rchb.f., Oncidium flexuosum (Kunth) Lindl., Oncidium longipes Lindl., and Prosthechea aemula (Lindl.) W.E. Higgins. Finally, the National History Museum in Paris preserves Sellow's specimens of Epidendrum faustum Cogn., Zygopetalum intermedium Lodd., Epistephium sclerophyllum Lindl., Brassavola martiana Lindl., Cattleya intermedia Hook., Cattleya loddigesii Lindl., and Cattleya coccinea Lindl. All known orchid specimens by Sellow were collected in Brazil. No orchid collections by him are known from Uruguay.

A number of orchid species were named in honor of Friedrich Sellow, among them: Angraecum sellowii Rchb.f., Campylocentrum sellowii Rolfe, Epidendrum sellowii Rchb.f., Oncidium sellowii Cogn., and Zygopetalum sellowii Rchb.f. 


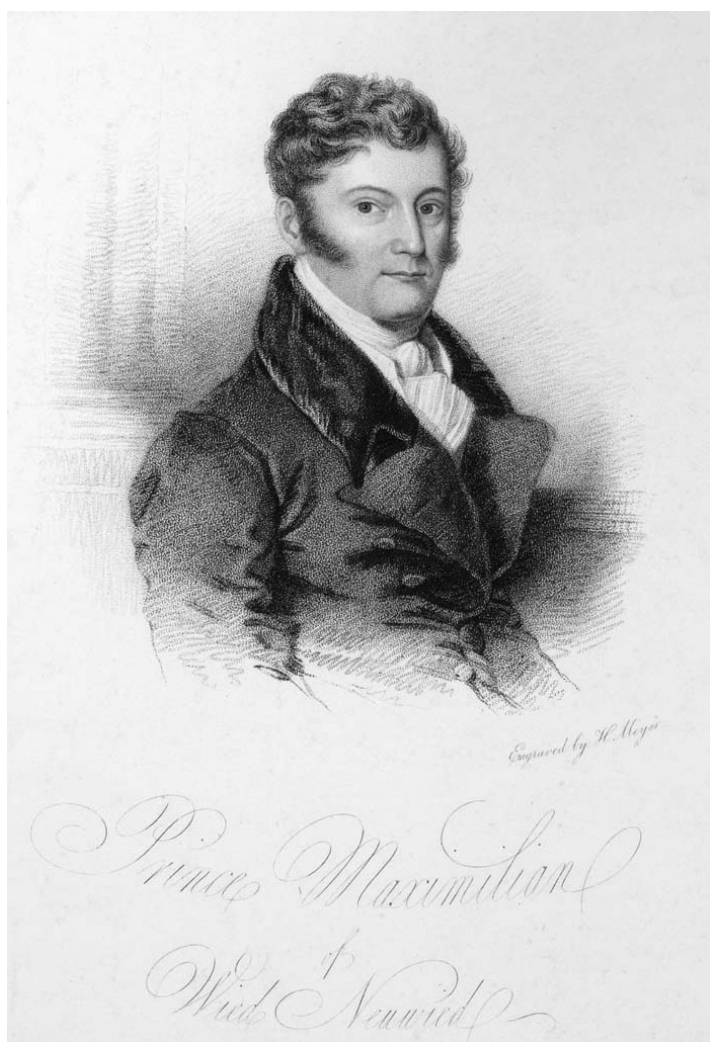

Figure 6. Prince Maximilian Alexander Philipp zu WiedNeuwied (1782-1867). Engraving by H. Meyer.

Prince and Naturalist: Maximilian Alexander Philipp zu Wied-Neuwied. Although perhaps more a zoologist than a botanist, German Prince Maximilian Alexander Philipp zu Wied-Neuwied (1782-1867) (Fig. 6) contributed many interesting Brazilian orchid specimens, today held at the herbaria of Vienna and the Herbarium Martii in Meise (Belgium).

His name is remembered in the orchid genus Neuwiedia Blume, from New Guinea, typified by N. veratrifolia Blume. Also, the orchid Maxillaria neowidii Rchb.f. was dedicated to him by Reichenbach from amongst his Brazilian collections. In his Beitrag zur Flora Brasiliens (= Contribution to the flora of Brazil) he complains about not having collected a larger number of orchids: "... from the abundant and beautiful Cactus, Epidendrum, Caladium, Dracontium and Loranthus, etc. did we obtain only a small number, since they normally grow on trunks and branches which are too high away from the ground" (WiedNeuwied 1823-1825:5).
Maximilian was born in Neuwied, on the Rhine, the grandson of the ruling count (after 1784 prince), Johann Friedrich Alexander of Wied-Neuwied. His education coincided with the end of the European Enlightenment, and he came under the influence of two of its most important figures: the anthropologist Johann Friedrich Blumenbach, under whom he studied biological sciences, and Alexander von Humboldt, who, years later, became Maximilian's mentor. In 1800 he joined the Prussian army, rising to the rank of major. The years of Maximilian's life which are of interest to our story begin in 1815, when leave from the army allowed him to lead an expedition to southeastern Brazil which lasted until 1817. According to K. V. Wied, "there is not the slightest doubt that his paramount interest in the American continent derived from the influence of the older and famous scholar [Humboldt], who henceforth was to remain his model, friend and mentor. From this time on the prince's most ardent and firmest purpose was an overseas expedition" (Wied 1954:17).

Maximilian sailed from London in May 1815 and arrived in Rio de Janeiro in July of the same year. In his company travelled two servants, an experienced taxidermist by the name of David Dreidoppel, and the Wied's family gardener Christian Simonis. In Rio de Janeiro, Wied was the guest of Baron von Langsdorff, the Russian Tsar's Consul General. We have already read about two other German naturalists, Georg Wilhelm Freyreiss and Friedrich Sellow, who were at the time ready to undertake a trip to the northeastern regions of Brazil, sponsored by Langsdorff. Wied decided to accompany them, traveling under the pseudonym of Baron Von Braunsberg.

According to Rodrigues de Moraes (2009), the three naturalists left Rio de Janeiro on August $4^{\text {th }} 1815$, taking 16 pack animals and 10 servants. From the district of Sao Cristovao they crossed the Bay of Guanabara by boat and went along the coast to the province of Espirito Santo, reaching Vitoria in November. While Wied and Freyreiss proceeded north, Sellow stayed behind for some time, collecting more botanical and zoological specimens. Wied and Freyreiss separated in Morro d'Arara, the latter returning to Espirito Santo. Finally, as has already been told, the three met again and after arriving in Salvador; the Prince departed for Europe on May 10th 1817. 


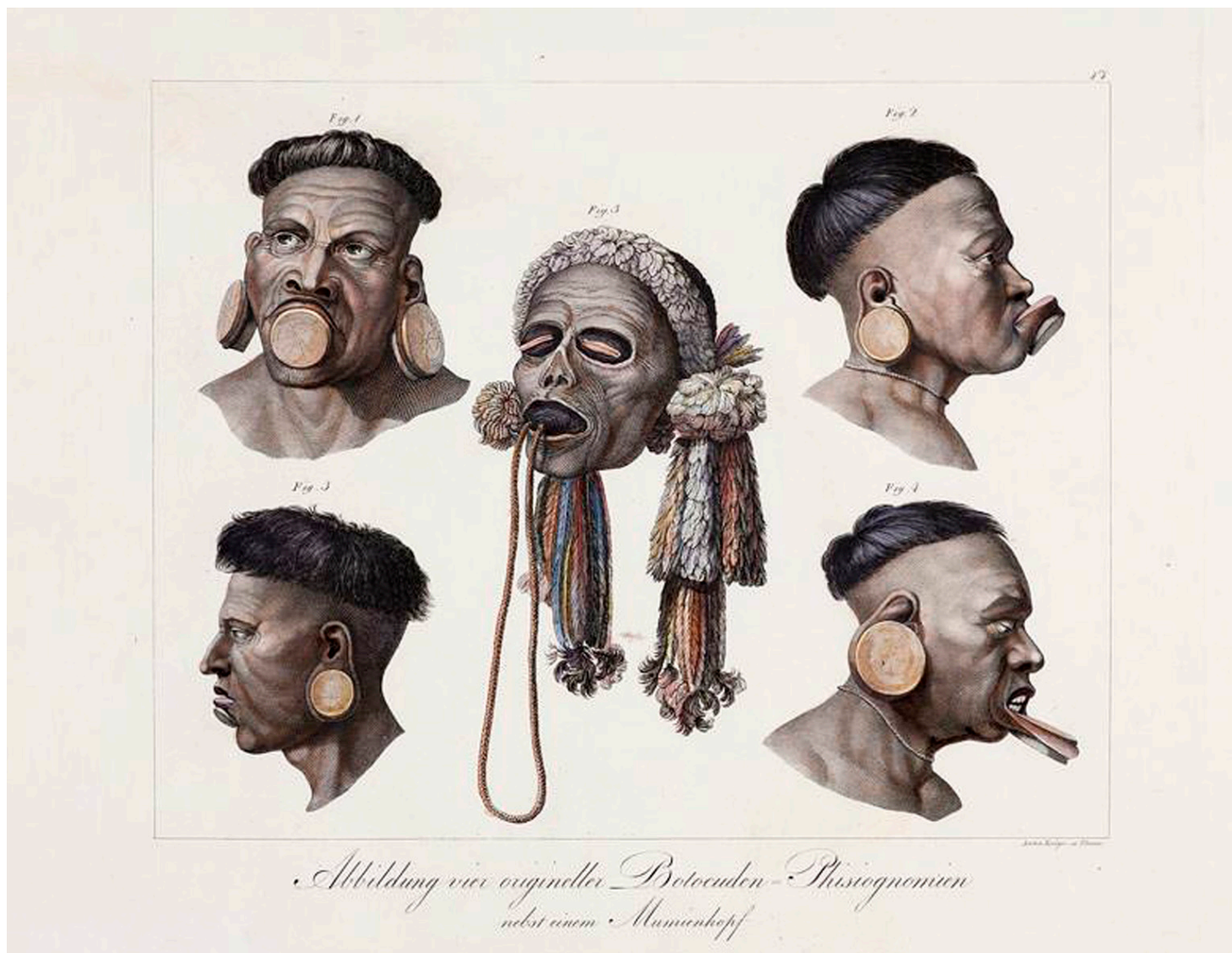

FIGURE 7. Botocudo heads. Engraving by Maximilian of Wied-Neuwied.

Maximilian amassed a wealth of information about native tribes, particularly the Puris and Botocudos, which is considered his most important contribution to human knowledge (Moraes, 2009: 19) (Fig. 7-8).

The rich botanical material collected by the Prince and by Sellow and Freyreiss is the best testimonial to the many hours they devoted to gathering plants, but of equal importance are Wied's citations and descriptions of many species in his works Reise nach Brasilien in 1815 bis 1817 (= Journey to Brazil in 1815 to 1817 ) (1820-21) and the already mentioned Beitrag zur Flora Brasiliens (1823-25), published after his return to Europe. His writings contain beautiful descriptions and illustrations of the Brazilian forests, their flora and fauna (Fig. 9).

Until his death, in 1867, Maximilian was an active member of the Leopoldina Academy. His merit has been fully acknowledged. Many learned societies elected him a member, and besides the already named orchids, a beautiful creeper from the primeval forests of Brazil was named Neowedia after him by Heinrich Schrader.

Among the orchid collections, Lindley, in his Folia Orchidaceae, mentions Zygostastes cornuta Lindl. (Fig. 10) and Oncidium varicosum Lindl. The Herbarium of the Vienna Natural History Museum holds specimens of Cyrtopodium punctatum (L.) Lindl., Eltroplectris calcarata (Sw.) Garay \& H.R.Sweet, and Ionoposis utricularioides (Sw.) Lindl. But the largest number of orchid specimens collected by Wied in Brazil can be found in the Herbarium Martii at Meise, Belgium, among which we find Eltroplectris calcarata, Aspidogyne argentea (Vell.) Garay, Brassavola flagellaris Barb.Rodr., Campylocentrum micranthum (Lindl.) Rolfe, Cattleya amethystoglossa Lindl. \& Rchb.f. ex Warner, C. сеrnua (Lindl.) Van den Berg, Cyrtopodium paniculatum (Ruiz \& Pav.) Garay, Habenaria pratensis (Lindl.) Rchb.f., Ionopsis 


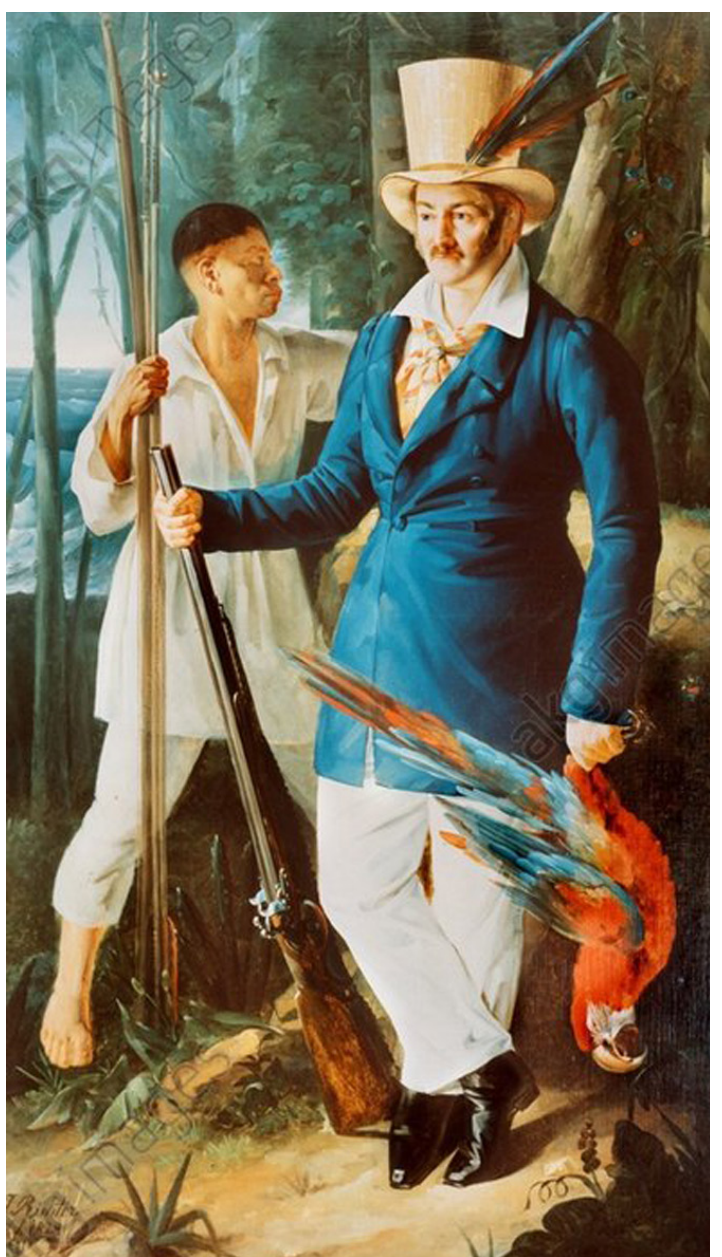

Figure 8. Maximilian with Botocudo Indian. Painting by Johann Heinrich Richter, 1828.

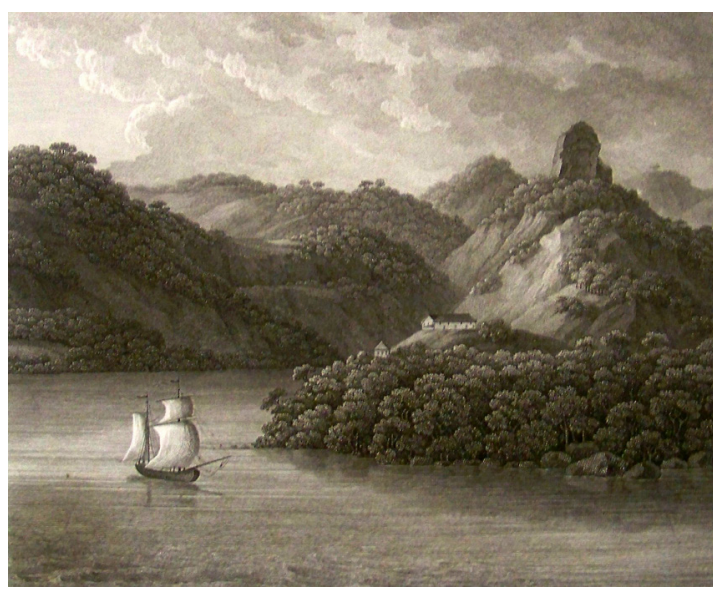

FIGURE 9. Tucutucuara River, Espirito Santo. By Maximilian of Wied-Neuwied.

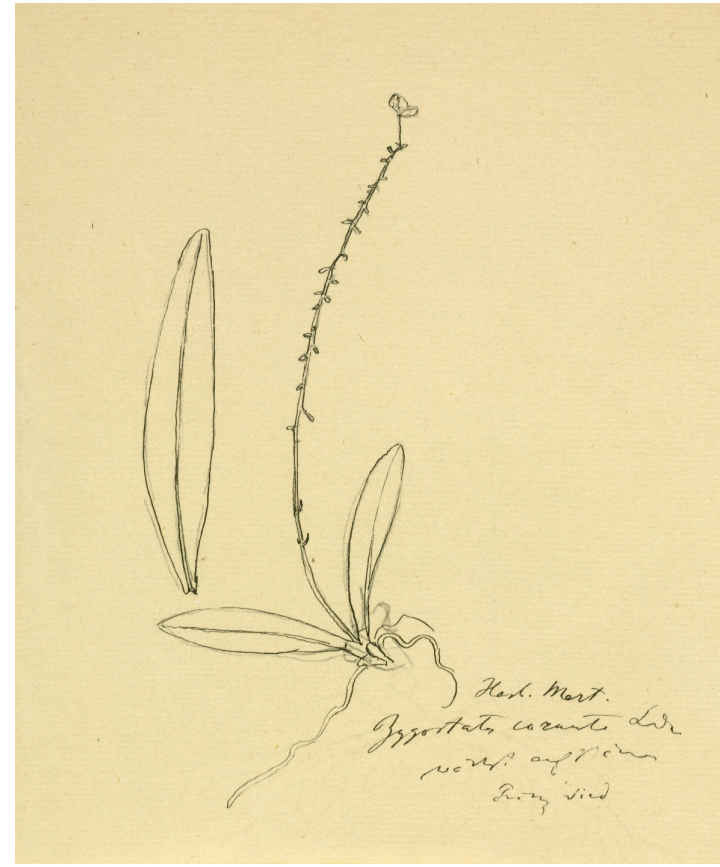

FiguRE 11. Zygostates cornuta Lindl. Reichenbach's sketch from Lindley Herbarium sheet at Vienna (W0024035).

paniculata Lindl., Maxillaria neowiedii, Mesadenella cuspidata (Lindl.) Garay, Oncidium cimiciferum (Rchb.f.) Beer, Oncidium pumilum Lindl., Oncidium pusillum (L.) Schltr., Oncidium varicosum Lindl., Pleurothallis articulata Lindl., and Rodriguezia rigida Rchb.f.

Augustin François Cesar Prouvençal de SaintHilaire. Son of an artillery officer and belonging to the French landowning nobility, Augustin François Cesar Prouvençal de Saint-Hilaire (1779-1853) (Fig. 11) was born in the city of Orléans. From his early youth, he showed his vocation for natural history, and when forced by the French Revolution to emigrate to Germany, he made the acquaintance of the eminent botanist Carl Segismund Kunth.

He advanced in his career as a botanist and was appointed professor at the Natural History Museum in Paris. Through contacts, he was called to form part of a mission to Brazil in 1816, promoted by the Duc de Piney-Luxembourg, Charles Emmanuel Sigismond de Montmorency-Luxembourg — French ambassador to the court of Portugal — and financed by King Louis XVIII. The expedition also had a political 


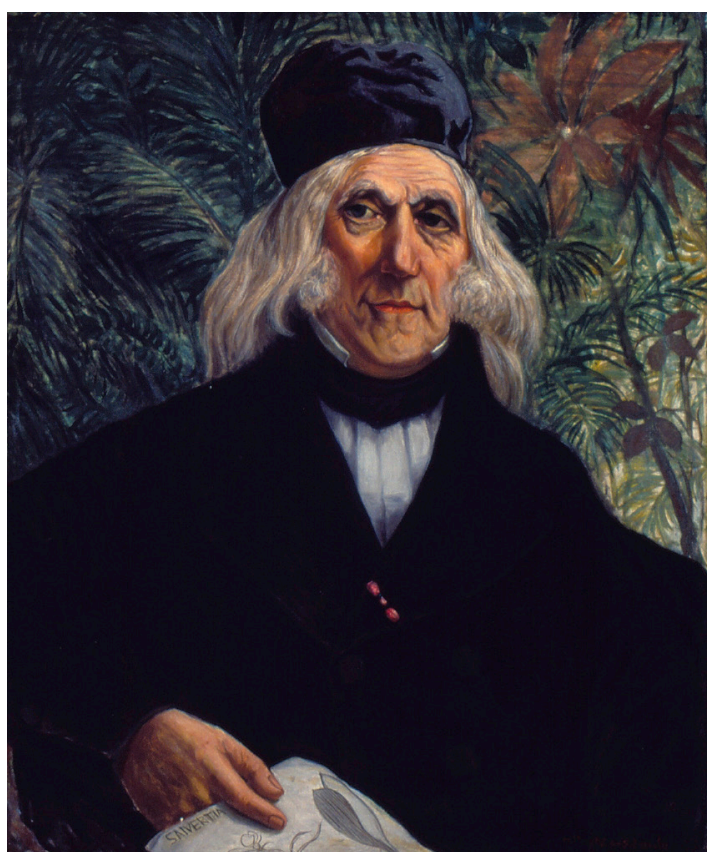

Figure 11. Augustin François Cesar Prouvençal de SaintHilaire (1799-1853). Portrait by Henrique Manzo. Museu Paulista.

character, as one of its objectives was to solve border conflicts between French Guyana and the Portuguese government of King João VI.

Saint-Hilaire arrived in Rio aboard the frigate Hermione in June 1816. In December of that year he started on his first excursion, in the company of Baron von Langsdorff, to explore the province of Minas Gerais. In the village of Vila Rica (Fig. 12) they were guests in the house of Wilhelm von Eschwege, who had been the host of Georg Freyreiss a few years earlier. The two explorers returned to Rio in March

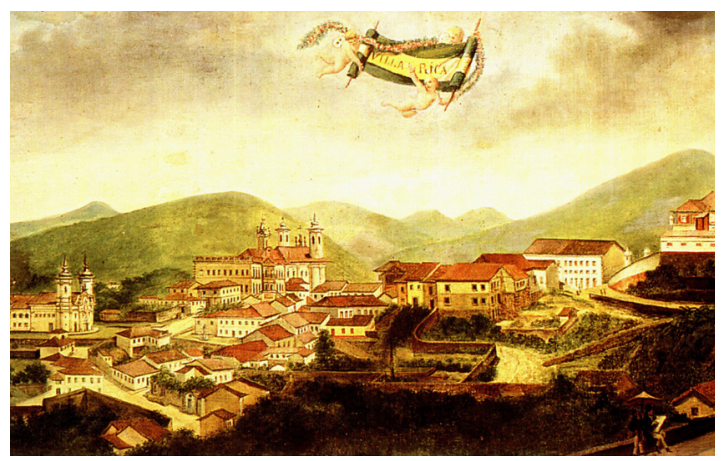

Figure 12. View of Vila Rica. by Arnaud Julien Pallière (fragment). of 1818. Other excursions, all financed by the French government, took Saint-Hilaire through the provinces of Rio de Janeiro and Espirito Santo (August through November, 1818); Minas Gerais again, Goiás and Sâo Paolo from January to October of 1819; Santa Catarina, Rio Grande do Sul and Cisplatina (today the Republic of Uruguay) (December 1819 to June 1821); and finally, once more to Minas Gerais and Sâo Paolo, from January to May of 1822 . In the first days of August of that year, he returned to France, never to return again to South America.

In France, Saint-Hilaire concentrated on publishing the results of his six years of travel through Brazil. The results of his study of its rich flora of were published in several books and numerous articles in scientific journals. The works for which he is best known are: Histoire des plantes les plus remarquables du Brésil et de Paraguay (= History of the most noteworthy plants of Brazil and Paraguay), published in 1824; Flora Brasiliae Meridionalis (= Flora of southern Brazil), published in three volumes between 1825 and 1832 in conjunction with A. de Jussieu and J. Cambessèdes; Plantes usuelles des Brésiliens (= Usual plants of the Brazilians), also in conjunction with De Jussieu and Cambessèdes, printed in 1827-1828; and Voyage dans le district des diamants et sur le littoral du Brésil (= Voyage through the diamond district and along the coast of Brazil), in two volumes, published in 1833. Unfortunately, and perhaps surprisingly, the family Orchidaceae is not mentioned in these works.

For his work, he was appointed to the Prussian Academy of Sciences, the French Academy, the Linnean Society, the Academy of Sciences in Lisbon, The Historic and Geographic Institute in Rio de Janeiro, and the Medical Society of Rio de Janeiro.

Saint-Hilaire died in Orléans on September $30^{\text {th }} 1853$.

Dozens of specimens of Orchidaceae can be found amongst Saint-Hilaire's botanical collections, most of them at the Martius Herbarium in Meise (Belgium) and at the National History Museum in Paris. It must be said at this point that although the author does not intend to enumerate each and all orchid specimens collected by every one of the collectors and botanists mentioned in this work, an exception is made here with Saint-Hilaire only to give proof of his enormous contribution to the orchidology of Brazil, Paraguay and Uruguay in a period of barely six years. The total 
number of botanical specimens collected by SaintHilaire in South America - considering only those held in Paris - amounts to 18,248, of which 10,263 were collected in Brazil.

Meise holds the following specimens: Habenaria inconspicua Cogn., H. poissoniana Cogn., H. trifida Kunth, Oncidium gomesii Cogn., Pelexia bonariensis (Lindl.) Schltr., P. laminata Schltr., P. loefgrenii (Porsch) Schltr., Pelexia P. (Rchb.f. \& Warm.) Schltr., P. stenantha (Cogn.) Schltr., Pteroglossa hilariana (Cogn.) Garay, and Skeptrostachys latipetala (Cogn.) Garay. But Paris has by far the richest collection of specimens collected by Saint-Hilaire, a collection that shows him as the most prolific orchid collector of his time: Acianthera bicarinata (Lindl.) Pridgeon \& M.W. Chase, A. sonderana (Rchb.f.) Pridgeon \& M.W.Chase Aspidogyne commelinoides (Barb. Rodr.) Garay, Bipinnula gibertii Rchb.f., B. montana Arechav., B. penicillata (Rchb.f.) Cisternas \& SalaTsar, B. polysyka Kraenzl., Bletia catenulata Ruiz \& Pav., Brachystele bracteosa (Lindl.) Schltr., B. camporum (Lindl.) Schltr., Brassavola flagellaris, B. tuberculata Hook., Bulbophyllum weddellii (Lindl.) Rchb.f., Campylocentrum densiflorum Cogn., Catasetum discolor (Lindl.) Lindl., C. gardneri Schltr., Cattleya amethystoglossa, C. bicolor Lindl., C. caulescens (Lindl.) Van den Berg, C. cernua, Cattleya cinnabarina (Bateman ex Lindl.) Van den Berg, C. coccinea (Lindl.) Van den Berg, C. crispa Lindl., C. crispata (Thunb.) Van den Berg, C. forbesii Lindl., C. fournieri (Cogn.) Van den Berg, C. longipes (Rchb.f.) Van den Berg, Cleistes castaneoides Hoehne, C. exilis Hoehne, C. brasiliensis (Barb.Rodr.) Schltr., C. metallina (Barb. Rodr.) Schltr., C. paranaensis (Barb.Rodr.) Schltr., $C$. pluriflora (Barb. Rodr.) Schltr., C. rodriguesii (Cogn.) Campacci, Comparettia coccinea Lindl., Cranichis candida (Barb. Rodr.) Cogn., Cyclopogon elatus (Sw.) Schltr., Cyrtopodium aliciae L. Linden \& Rolfe, $C$. blanchetii Rchb.f., C. brandonianum Barb.Rodr., $C$. flavum (Nees) Link \& Otto ex Rchb., C. gigas (Vell.) Hoehne, C. glutiniferum Raddi, C. hatschbachii Pabst, C. pallidum Rchb.f. \& Warm., C. parviflorum Lindl., $C$. cf. poecilum Rchb.f. \& Warm., Elleanthus brasiliensis Rchb.f., E. crinipes Rchb.f., Eltroplectris cogniauxiana (Cogn.) Pabst, E. triloba (Lindl.) Pabst, Epidendrum avicula Lindl., E. dendrobioides Thunb., E. dichromum Lindl., E. martianum Lindl., E. paniculatum Ruiz \&
Pav., E. paranaense Barb. Rodr., E. saxatile Lindl., E. secundum Jacq., Epistephium lucidum Cogn., E. sclerophyllum Lindl., Eulophia alta (L.) Fawc. \& Rendle, Galeandra beyrichii Rchb.f., G. junceoides Barb. Rodr., G. xerophila Hoehne, Gomesa imperatorismaximiliani (Rchb.f.) M.W.Chase \& N.H. Williams, G. laxiflora Klotzsch ex Rchb.f., Habenaria armata Rchb.f., H. brevidens Lindl., H. cryptophila Barb. Rodr., H. edwalli Cogn., H. glaucophylla Barb. Rodr., H. guilleminii Rchb.f., H. gustavo-edwallii Hoehne, H. jaguariahyvae Kraenzl., H. johannensis Barb. Rodr., H. macronectar (Vell.) Hoehne, H. cf. melvillei Ridl., Habenaria cf. nuda Lindl., H. paranaensis Barb. Rodr., H. petromedusa Webb, H. petalodes Lindl., H. pleiophylla Hoehne \& Schltr., H. pungens Cogn. ex Kuntze, H. regnelli Cogn., H. repens Nutt., H.cf. rupicola Barb. Rodr., H. schwackei Barb. Rodr., H. subviridis Hoehne \& Schltr., H. tamanduensis Schltr., H. taubertiana Cogn., H. trifida Kunth, H. warmingii Rchb.f., Ionopsis utricularioides (Sw.) Lindl., Isabelia violacea (Lindl.) Van den Berg \& M.W.Chase, Leptotes bicolor Lindl., Liparis nervosa (Thunb.) Lindl., Hexalectris spicata (Walter) Barnhart, Koellensteinia eburnea (Barb. Rodr.) Schltr., Malaxis parthoni C. Morren, Mesadenella cuspidata (Lind1.) Garay, Maxillaria pumila Hook. Mesadenus glaziovii (Cogn.) Schltr., Miltonia regnellii Rchb.f., Neottia aestivalis Lam., Octomeria wawrae Rchb.f. ex Wawra, Oncidium barbatum Lindl., O. batemanianum Parm. ex Knowles \& Westc., O. baueri Lindl., O. divaricatum Lindl., $O$. flexuosum Sims, O. fuscans Rchb.f., O. hydrophilum Barb. Rodr., O. praetextum Rchb.f., O. uliginosum Barb. Rodr., Ornithidium pendens (Pabst) Senghas, Pelexia bonariensis (Lindl.) Schltr., P. laminata Schltr., P. loefgrenii (Porsch) Schltr., P. orthosepala (Rchb.f. \& Warm.) Schltr. P. stenantha (Cogn.) Schltr., Phymatidium delicatulum Lindl., Physurus pictus Lindl., Prescottia micrantha Lindl., P. montana Barb. Rodr., P. plantaginea Lindl., P. rodeiensis Barb. Rodr., P. stachyodes (Sw.) Lindl., Prosthechea fragrans (Sw.) W.E.Higgins, P. vespa (Vell.) W.E.Higgins, Pteroglossa hilariana (Cogn.) Garay, P. macrantha (Rchb.f.) Schltr., Rodriguezia microphylla Barb.Rodr., Rodriguezia secunda Kunth, Sacoila duseniana (Kraenzl.) Garay, $S$. lanceolata (Aubl.) Garay, Sauroglossum elatum Lindl., Skeptrostachys balanophorostachya (Rchb.f. \& Warm.) Garay, S. congestiflora (Cogn.) Garay, S. gigantea 


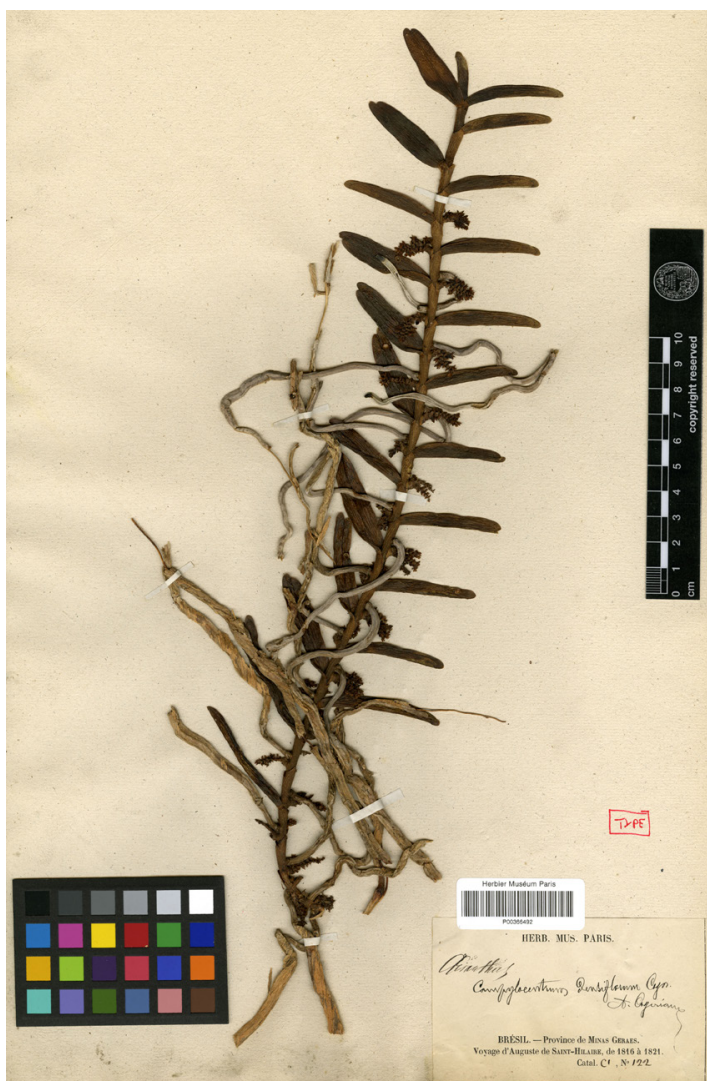

FIGURE 13. Type specimen of Campylocentrum densiflorum Cogn., collected by Saint-Hilaire. National History Museum in Paris (P00366492)..

(Cogn.) Garay, S. hebesepala (Barb. Rodr.) Cogn., S. latipetala (Cogn.) Garay, S. paraguayensis (Rchb.f.) Garay, Specklinia grobyi (Bateman ex Lindl.) F. Barros, Stelis catharinensis Lindl., S. omalosantha BarbRodr., S. rodriguezii Cogn., Stenorhynchus arrabidae Rchb.f., Stenorrhynchos hassleri Cogn., Theodorea gomezoides Barb. Rodr., Trichocentrum cebolleta (Jacq.) M.W.Chase \& N.H.Williams. T. pumilum (Lind1.) M.W.Chase \& N.H.Williams, Veyretia rupicola (Garay) F. Barros, Zygopetalum crinitum Lodd., Z. intermedium Lodd. ex Lindl., Z. mackaii Hook., and Z. sellowii Rchb.f.

Other orchid collections by Saint-Hilaire which were unknown to botany at that time were Campylocentrum densiflorum (Fig. 13) and Stelis rodriguesii, both described by Cogniaux.

Stenorrhynchos hilarianum Cogn. (Fig. 14), an orchid species which was new to science, was dedicated to Saint-Hilaire.

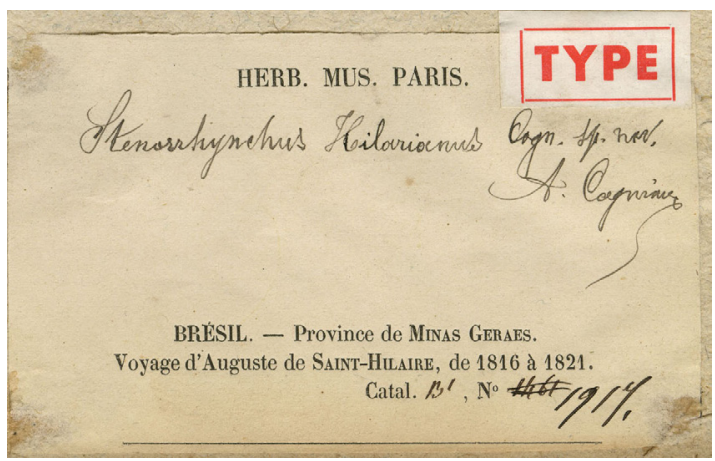

FIGURE 14. Herbarium label of the holotype of Stenorrhynchus hilarianum Cogn., collected by Saint-Hilaire. National History Museum in Paris (P00345645).

William John Swainson. An English naturalist specializing in zoology, William John Swainson (17891855) (Fig. 15) was born in Newington, London, the son of John Timothy Swainson, one of the first fellows of the Linnean Society. He joined the Army and toured Malta and Sicily but was forced to return to England due to ill health. Following in his father's footsteps, in 1815 he became a fellow in the Linnean Society.

In 1816 he was invited by the explorer Henry Koster to accompany him to Brazil. Koster was born in Portugal and lived in Brazil for several years, becoming famous for his book Travels in Brazil, published in 1816 .

Swainson wrote: "About this time, the jealousy of the Portuguese government relaxed, and they opened Brazil to European researches. Mr. Koster had just published his travels: he gave me such a picture of the zoological riches of the country he had just quitted, that I resolved to accompany him on his second journey; and we left England together on the 22d of November, 1816" (Swainson 1840: 344). They landed in Pernambuco in the first months of 1817 . However, the outbreak of the 1817 'Revolution of Pernambuco' (which demanded the independence of Brazil from Portugal) forced Swainson to stay in the village of Olinda, where he spent his time collecting plants and animals.

Let us learn about the rest of Swanson's relatively short but fruitful journey in his own words: "The insurrection being put down, I immediately engaged a guide and three Indians, with whom I set off, overland, for the Rio St. Francisco. We found the draught, however, so great, that we were obliged to reach Bahia by water [In Bahia Swainson met naturalists Sellow and 


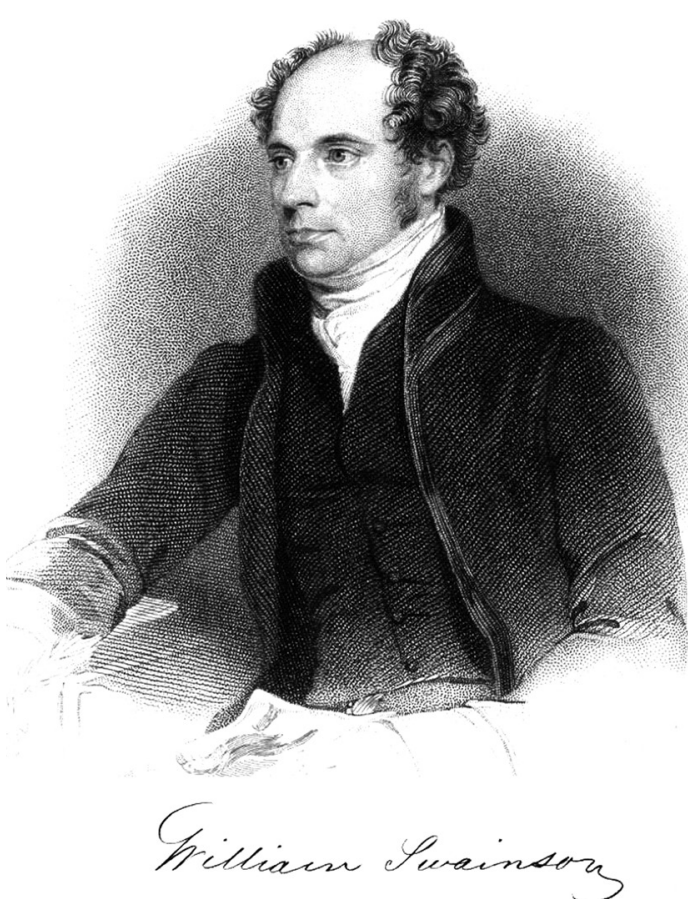

FIGURE 15. Portrait of William John Swainson (1789-1855).

Unknown artist.

Freyreiss, who were part of the expedition of Maximilian von Wied-Neuwied]. After investigating several parts of that province, we proceeded by sea to Rio de Janeiro. Here I met with Dr. Langsdorff, the late Dr. Raddi of Florence, and some of the German naturalists sent by the court of Austria [Dr. von Martius and Dr. von Spix]. With Langsdorff I made several excursions, and in four months so enriched my collections, that I became almost satiated. I felt I had now more than enough to study and arrange for years to come. I therefore broke up my party, embarked for England, and once more, -like a bee loaded with honey- returned to my father's house" (Swainson 1840: 344).

Swainson returned to England in 1818. His harvest comprised over 20,000 insects, 1,200 species of plants, drawings of 120 species of fish, and about 760 bird skins.

In 1841 Swainson emigrated to New Zealand. He spent the rest of his life involved in property management, history-related publications and forestry research in New Zealand, Tasmania and Australia. He died in New Zealand in 1855. Koster, who never left Brazil again, died in Pernambuco in 1820, at the age of 27.

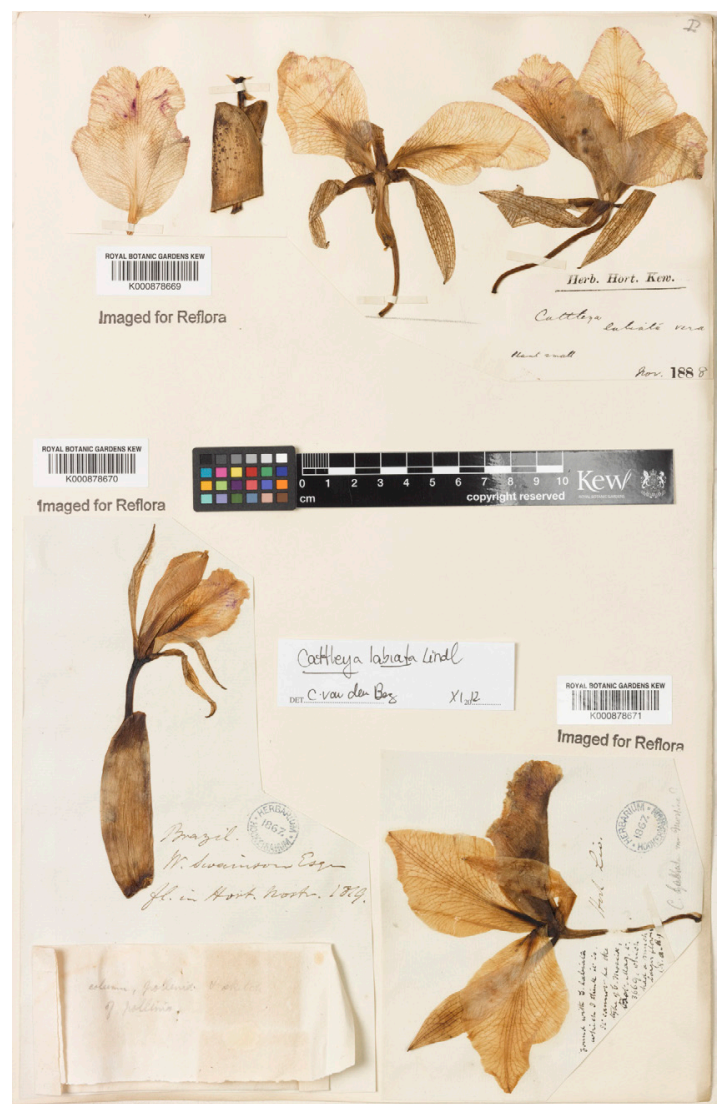

Figure 16. Cattleya labiata Lindl. Herbarium specimen by Swainson at the Royal Botanic Gardens, Kew.

Swainson's orchids: the genus Cattleya. Swainson was not a prolific collector, but he was a very selective one. Only a few orchids can be found among Swanson's specimens: Oncidium barbatum Lindl., Catasetum hookeri Lindl., and Cattleya labiata Lindl. But it would be the latter that brought Swainson fame, as he had collected the plant that would be the type for one of the most popular orchid genera of all times (Fig. 16-17). A first plant of this genus had been published in Loddiges' Botanical Cabinet (plate 337), where it was illustrated and described as Epidendrum violaceum in 1819 (Fig. 18) (Dr. William Hooker had already bloomed an allied species in his greenhouse in 1818.) The plant had been collected by Swainson in the Organ Mountains, some 100 kilometers north of Rio de Janeiro (other sources say in Pernambuco, about 1,600 kilometers north-east from Rio). Either Hooker or Cattley forwarded the flowering plant to John Lindley, who described it as Cattleya labiata in 


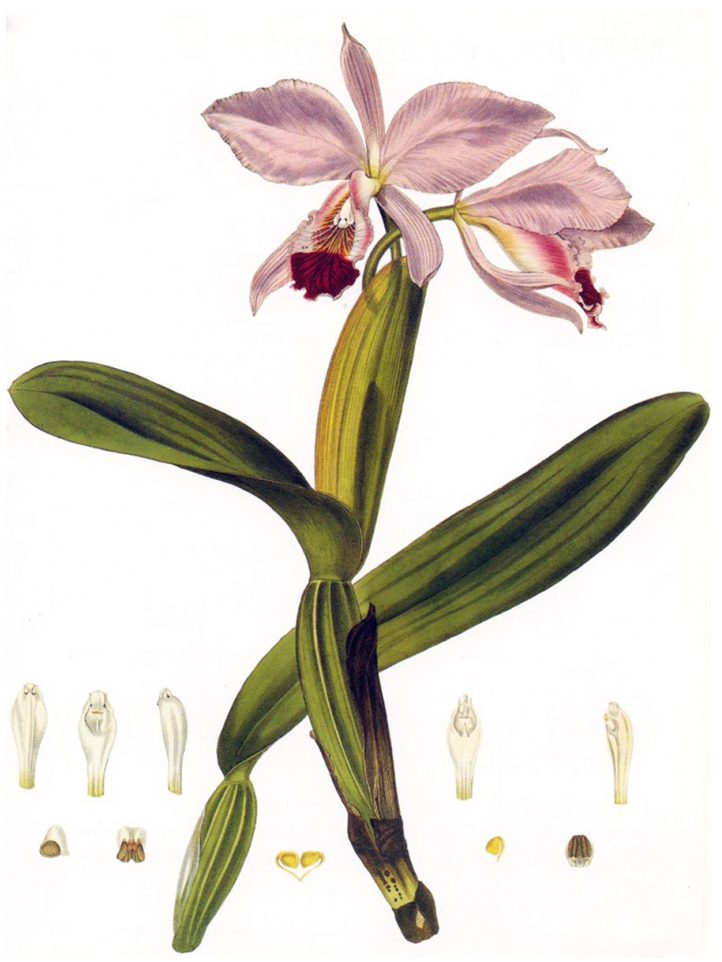

Figure 17. Cattleya labiata Lindl. Collectanea Botanica, 1814 , plate 33 .

his Collectanea Botanica, plate 33 (1824), establishing a new genus which he named in honor of Mr. Cattley. A second specimen of this plant - as rumor has it had been used as packing material in a consignment of orchids sent by Swainson to a reputed amateur orchid grower, Mr. William Cattley, of Barnet near London.

As with so many other visitors to Brazil in those years, Swanson was helped and guided in his exploration of Brazil's exuberant nature by Grigory von Langsdorff.

Charles Gaudichaud-Beaupré. French botanist Charles Gaudichaud-Beaupré (1789-1854) would make important botanical collections in Brazil, Chile and Peru, between 1830 and 1832 (this will be addressed in a future work). However, in 1817-1818, and again in 1820, he passed briefly through Rio de Janeiro during Louis Claude de Saulces de Freycinet's world's circumnavigation aboard the Uranie. The Uranie arrived in Rio de Janeiro on December 6th 1817 and departed for Cape Town on January 30th 1818. On her return voyage the Uranie sank in a

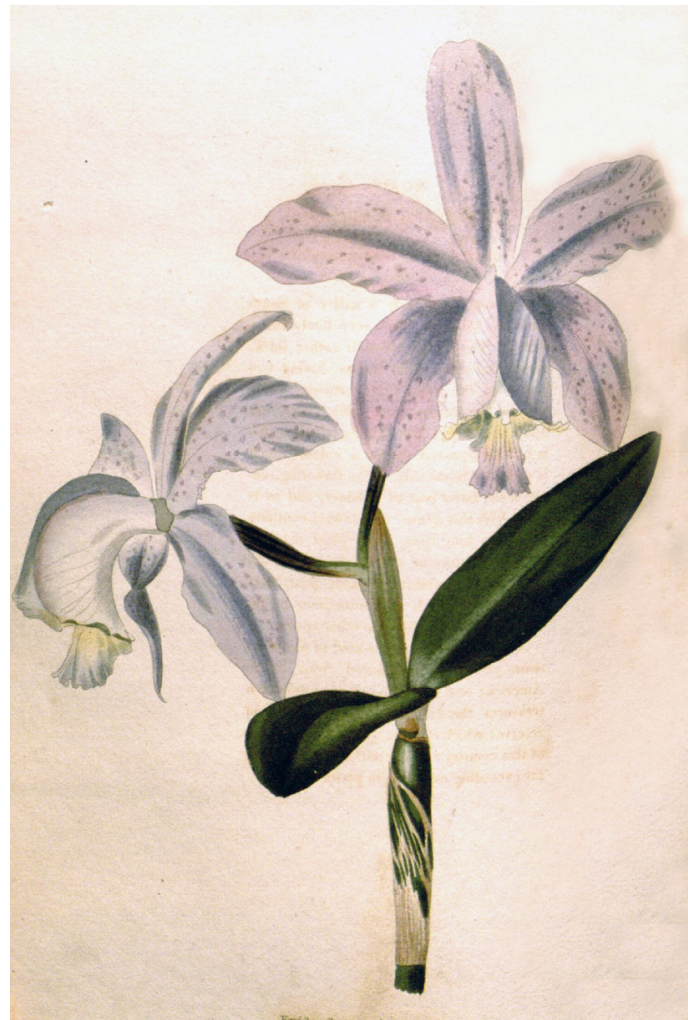

FIgURE 18. Epidendrum violaceum Lodd. Botanical Cabinet, 1819, vol. 4: plate 337.

storm near the Falkland Islands. Freycinet and his crew managed to save themselves and purchased an American vessel which they renamed Physicienne, They arrived again in Rio on June 19th 1820, leaving for France on September 13th of that year.

No records of botanical collections made by Gaudichaud-Beaupré during these visits to Rio have been found, mainly because most of the collections were lost in the wreck of the Uranie. A number of herbarium specimens at the National History Museum in Paris are listed as having been collected by Gaudichaud-Beaupré in Brazil during the Uranie expedition. However, the specimens all bear dates of 1833 and 1834. They must, therefore, belong to Gaudichaud-Beaupré's later expeditions to South America.

However, in the narrative of the earlier expedition, Voyage autour du monde... exécuté sur les corvettes de S. M., "l'Uranie" et "la Physicienne", pendant les années 1817, 1818, 1819 et 1820, GaudichaudBeaupré gave a beautiful description of the vegetation surrounding the capital of Brazil, marvelling at the 


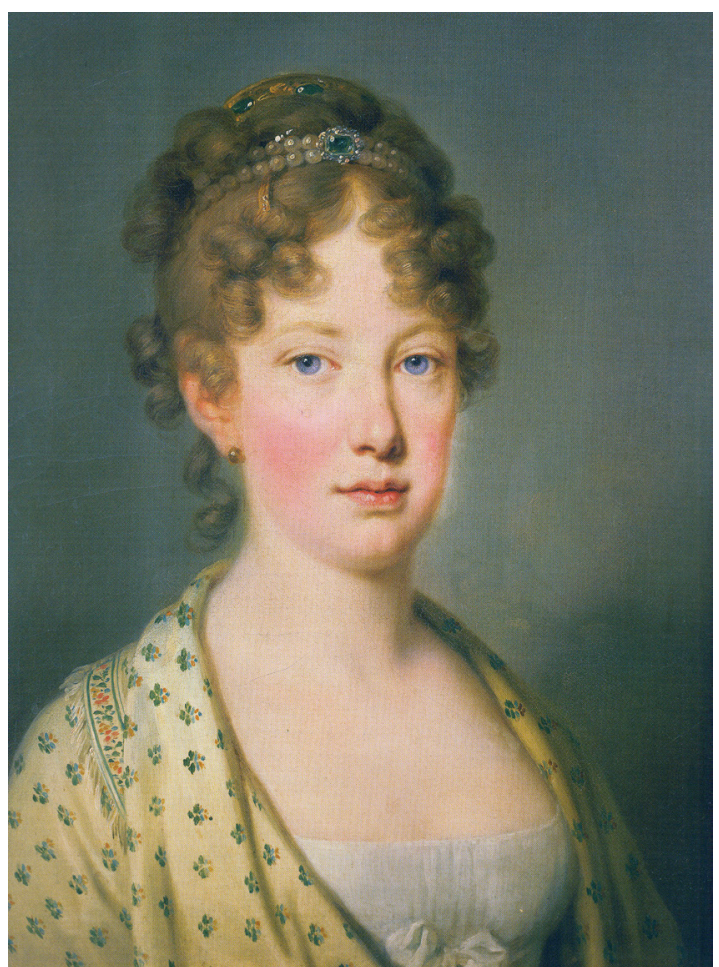

FIgURE 19. Caroline Josepha Leopoldina Franziska Ferdinanda of Austria (1797-1826). Portrait by Joseph Kreutzinger.

orchids, among which he names the genera Stelis, Epidendrum, Limodorum, Ionopsis, Cymbidium, and Anguloa. He also names some of the scientists who had explored the botany of Brazil; he mentions Prince Maximilian von Wied-Neuwied, Auguste de SaintHilaire, von Spix and von Martius, Giuseppe Raddi and Baron von Langsdorff. Baldini \& Guglielmone (2012) assume that he made botanical excursions with Raddi in December 1817 and January 1818.

Further reference to Langsdorff is made in the journal of Rose de Freycinet, Louis de Freycinet's wife. She praises the musical abilities of Madame von Langsdorff, who played piano at a party given at Langsdorff's house to entertain the officers of the expedition during their first visit to Rio de Janeiro in December 1817.

Coincidentally, the draftsman accompanying Freycinet on the Uranie was Adrien-Aimé Taunay, who seven years later would be chosen by Langsdorff to be part of his own expedition to the interior of Brazil, from which the young French artist would never return.

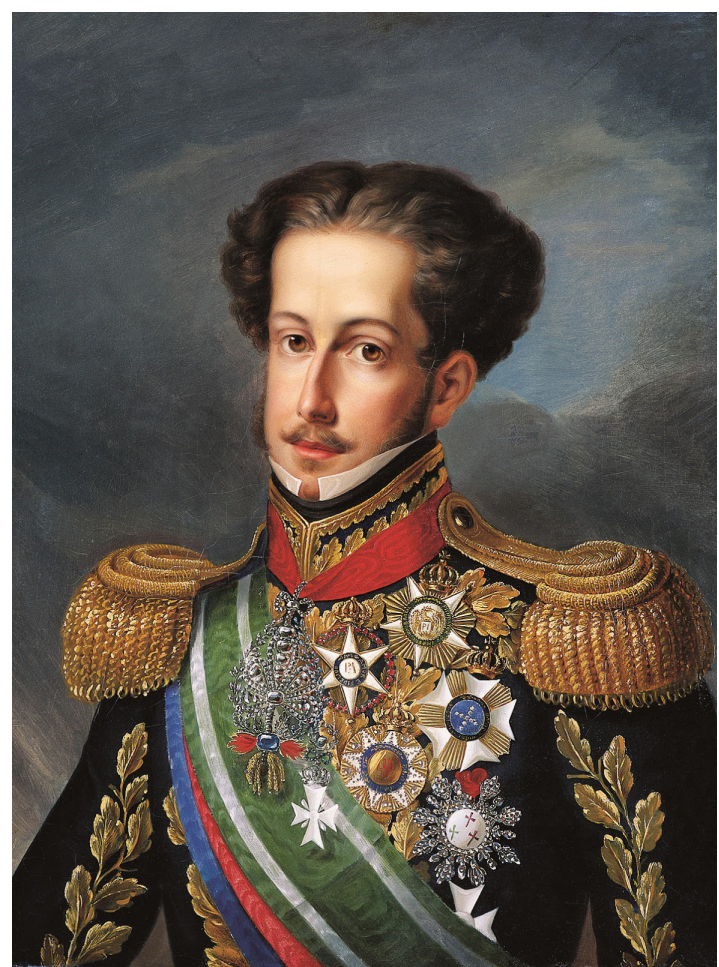

Figure 20. Pedro I of Brazil (1798-1834). Portrait by Simplicio Rodrigues de Sá.

The Austrian-German Expedition to Brazil. On May 13th 1817, in the Imperial Chapel of the Palace of Vienna, a marriage took place. Archduchess Caroline Josepha Leopoldina Franziska Ferdinanda of Austria (better known as Maria Leopoldina of Austria) (17971826) (Fig. 19), daughter of Francis I, Emperor of Austria, married Dom Pedro of Braganza (1798-1834), Crown Prince of the United Kingdom of Portugal, Algarve and Brazil, later Pedro I of Brazil and for a short period of time King Pedro IV of Portugal (Fig. 20).

The wedding had, however, one peculiarity: it was celebrated per procuram (by proxy). The bridegroom was 10,000 kilometers away in tropical Rio de Janeiro and was represented at the ceremony by Maria Leopoldina's uncle, Archduke Charles.

Among the 2,000 guests was Maximilian I Joseph, King of Bavaria, whose sympathy with France and the ideas of enlightenment were made manifest when he succeeded to the throne. He was deeply under the influence of Count Max Josef von Montgelas, one of the most ardent promoters of French ideas in Germany, 


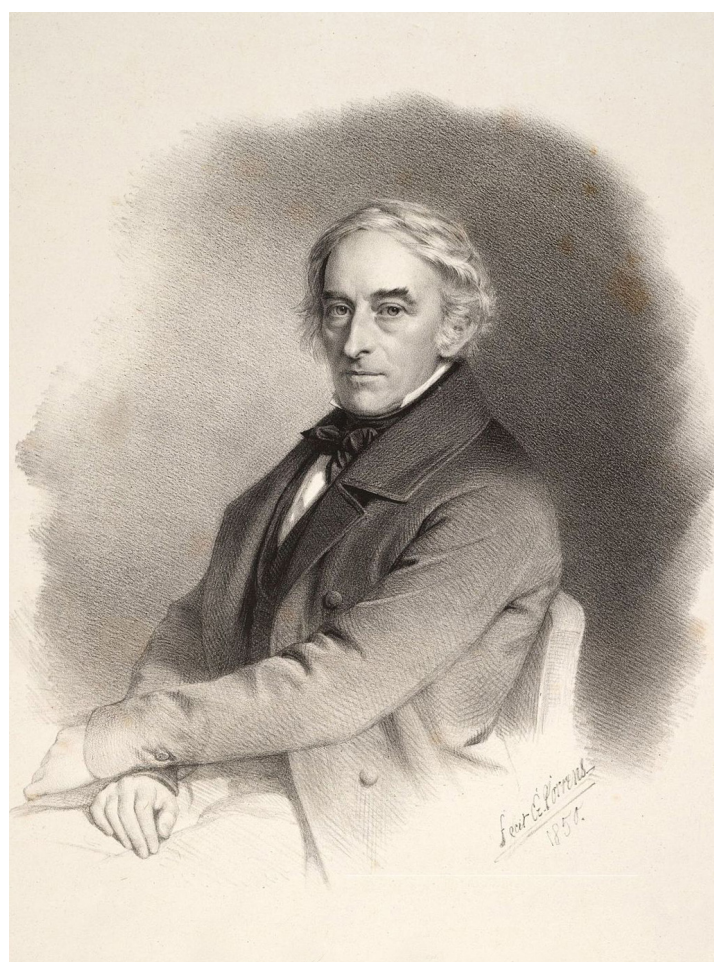

FIgure 21. Carl Friedrich Philipp von Martius (1794-1868).

Unknown artist.

who had acted for a time as his private secretary. Since the end of 1815, Maximilian had planned a scientific expedition to South America and chosen as its leaders Karl Friedrich Philipp von Martius (1794-1868) (Fig. 21), a Ph. D. in Botany from the University of Erlangen, and Johann Baptist Ritter von Spix (17811826) (Fig. 22), a prominent zoologist.

It was originally intended that the expedition would visit Buenos Aires and continue from there to Chile and Quito, returning to Europe via Caracas or Mexico. But financial difficulties obliged Maximilian to defer the execution of this project. It must have come, therefore, as quite a surprise to Maximillian, when he received an invitation to the wedding at the end of 1816, to learn that the Austrian Imperial Court had resolved to send some scientists to Brazil in the suite of the august bride. The surprise was compounded by the fact that, as Maximillian knew, the Austrian Emperor was opposed to "Enlightenment" and very well known for his ultra-conservative ideas. Notwithstanding, the golden opportunity was taken and arrangements were made for von Martius and von

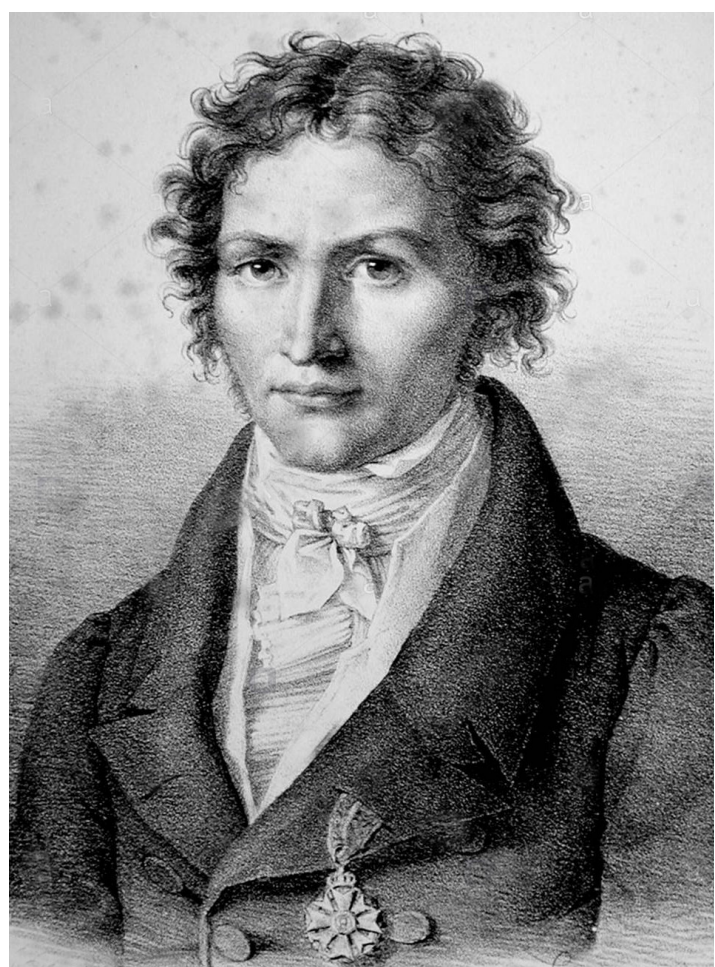

FiguRE 22. Johann Baptist Ritter von Spix (1781-1826). Unknown artist.

Spix to accompany the Austrian Expedition to Brazil.

In February 1817 the two German scientists set out for Vienna, where they met the scientists chosen by the Austrian Government to direct the expedition and who would be their fellow travellers. Among them were Professor Johann Christian Mikan from Prague (Botany and Entomology), Johann Baptist Emanuel Pohl (Mineralogy and Botany), Johann Natterer (Zoology) and the gardener Heinrich Wilhelm Schott. An important chronicler of the expedition would be the well-known landscape painter Thomas Ender, from whom we have a spectacular record of the journey, particularly the surroundings of Rio de Janeiro.

Giuseppe Raddi, Italian botanist, was sent by the Grand Duke of Tuscany to accompany the expedition. Together with Johann Buchberger (botanical illustrator) and several assistants, the group comprised a total of 14 travellers.

From Vienna, part of the expedition set out for Trieste (von Spix, von Martius, Mikan and Ender), sailing on April 10th 1817 aboard two frigates, the Austria and the Augusta. They sailed by way of Gibraltar, where 


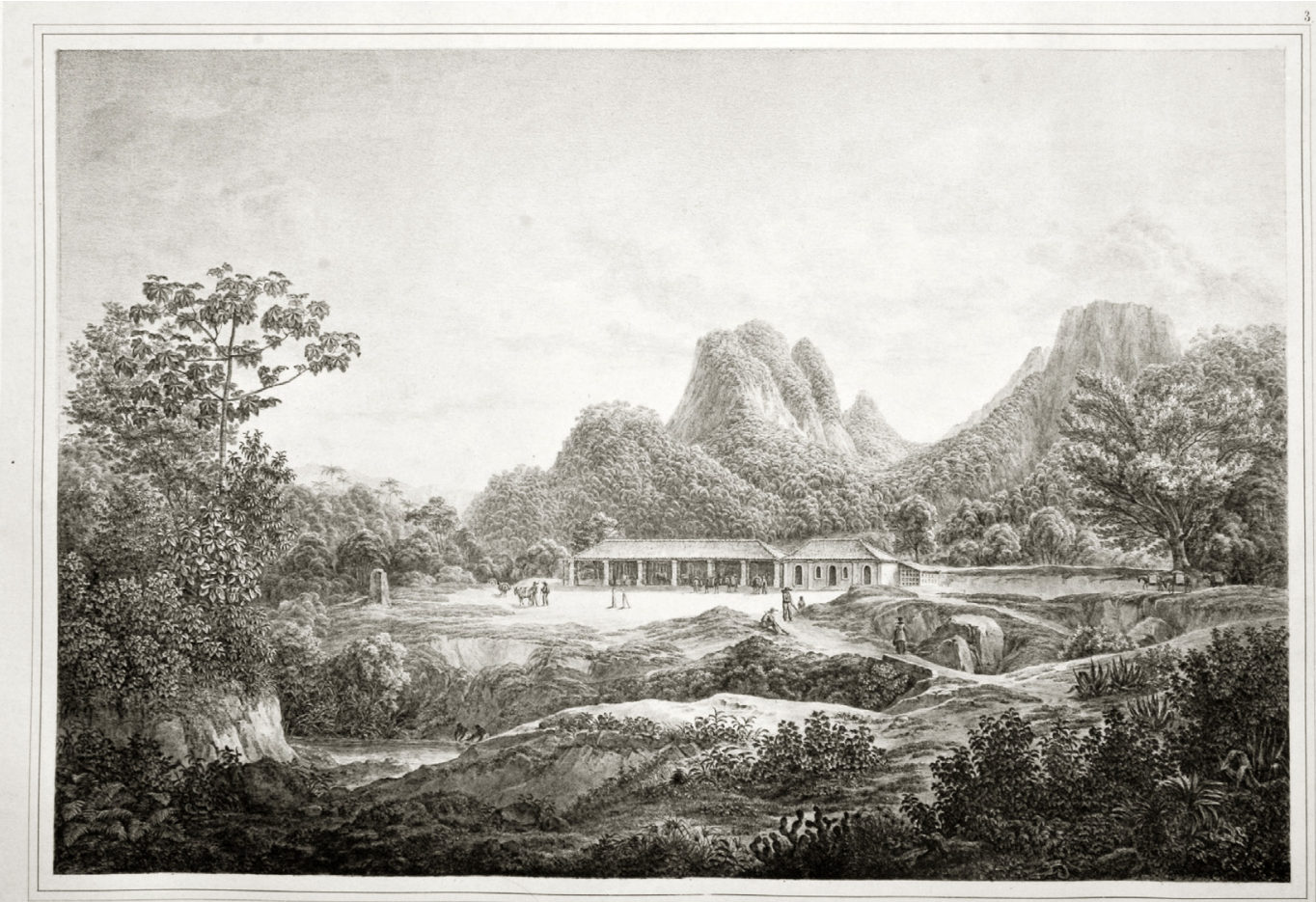

IVIANDIDCCA

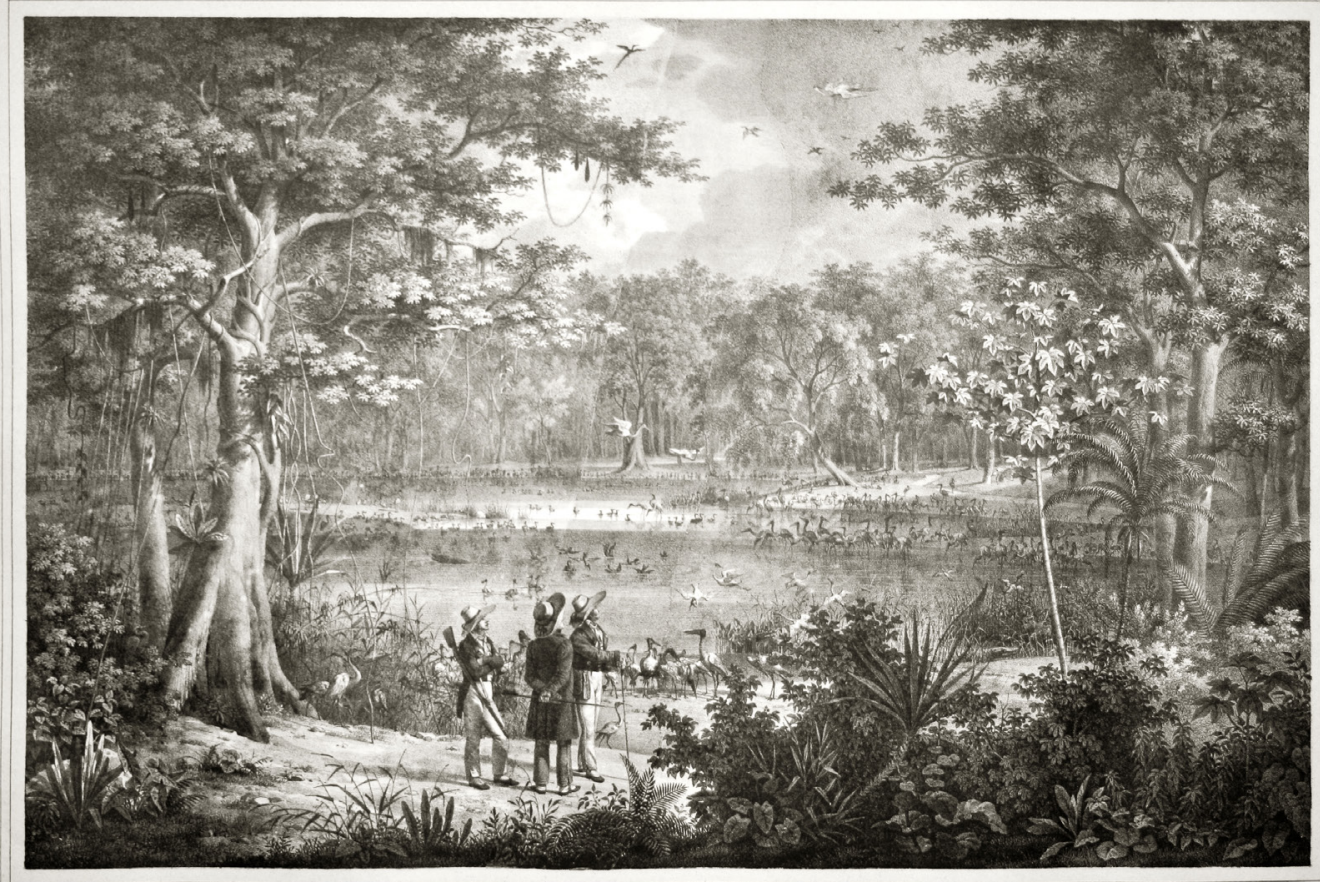

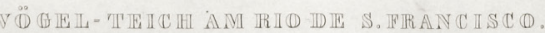


they had orders to wait for the Archduchess' convoy and accompany her to Rio de Janeiro. However, once in Gibraltar the orders were countermanded and they sailed on alone to Rio, where they arrived on July 14th. As could not have been expected otherwise, Baron von Langsdorff was immediately on the scene: "To our great satisfaction we soon met with the very obliging M. Von Langsdorff, the Prussian [sic] consulgeneral, who is well known in the literary world by his account of the voyage round the world, in which he accompanied Commodore Krusenstern. He welcomed us with the greatest cordiality; and several of our German fellow-countrymen, who had settled at Rio de Janeiro with mercantile views, endeavoured to serve us to the utmost of their power" ( Spix \& Martius1824: 132). Several months later, on November 5th, Her Imperial Highness Maria Leopoldina and her entourage made their solemn entrance into the harbour of Rio de Janeiro. With her came the rest of the expedition.

The wedding of Maria Leopoldina had become the pretext for one of the major scientific adventures of the 19th century, during which the expedition would travel over more than ten thousand kilometers through the interior of Brazil, discovering indigenous tribes, classifying unknown species of animals and plants, tracing maps and describing minerals. King Joâo could be happy: his daughter-in-law not only brought prestige to his dynasty, but also the culture of Europe to the very heart of South America (Moro 2012: 53).

For the first weeks in Rio de Janeiro, the members of the expedition spent their time becoming acquainted with the city and the local population, and making contacts with Brazilian and resident European scientists. Again, Langsdorff was at the center of all the action. There is nobody better than von Spix and von Martius themselves to give a description of the social, literary and scientific life of that time: "The hospitable residence of Mr. Von Langsdorff was a very agreeable place of resort in the evening for many Europeans residing at Rio de Janeiro. [...] So great a number of naturalists, or friends of natural history, had never yet been assembled here, as just at the time of our stay. The mutual communication of the observations and feelings which the luxuriance and the peculiarity of the vegetation inspired, became doubly attractive, through the charms of the environs. Mr. Von
Langsdorff inhabited a small country-house, on the declivity of the chain of hills which stretches from the city towards the south-west, and enjoyed from hence, amidst the fragrant shrubs of Brazil, an enchanting prospect over the city and part of the bay..." (Spix \& Martius 1824: 159-160). Von Langsdorff's role at that time can perhaps best be compared to that of George Ure Skinner in Guatemala some decades later, who in a similar way was the host to a large number of naturalists visiting the newly independent republics of Central America. At the Russian Consul's invitation, after having explored the neighbourhood of Rio de Janeiro, the expedition travelled to von Langsdorff's hacienda, to the north of the capital. They sailed along the coast to Porto Estrela and went from there overland to Fazenda Mandiocca, where von Langsdorff had built his house (Fig. 23).

\section{The Germans: Carl Friedrich Phillip von Martius and Johann Baptist Ritter von Spix. After a few} days at Mandiocca, Carl Friedrich Philipp von Martius and Johann Baptist Ritter von Spix returned to Rio, hoping to meet Maria Leopoldina's squadron and with it the rest of the naturalists. When eventually the rest of the expedition arrived, the Germans learned that the Austrian Government had decided to divide the exploration efforts into several smaller parties, which delayed things even further. Also, von Martius received a direct order from Munich not to prolong his journey over the term of two years. The whole party being present and taking into account the new directives, permission was asked for and received from the Brazilian Government. On December $8^{\text {th }}$ a small group comprising von Spix, von Martius, the already mentioned director of mines Baron Wilhelm von Eschwege, Thomas Ender, and a Mr. Dürming (German Consul at Antwerp, who had arrived in Rio a few weeks earlier) left Rio on the road to Sâo Paulo. On $1^{\text {st }}$ May 1818, after Dürming was forced to return to Rio in the company of Ender due to a broken leg, the remaining trio of travellers left for Diamantina, Minas Novas and then Montes Claros. Early in January 1819 they were in Minas Gerais, and continued across the Rio San Francisco (Fig. 24). Martius and von Spix would then explore a large part of Brazil over the next two and a half years, until they arrivedin Belém in 
April 1819. They sailed for Europe on June $13^{\text {th }}$ of that year. They would not see von Langsdorff again.

But let us follow the journey in detail. From May 1818 the two Germans headed north-northeast to Carinhanha and as far as the Serra Geral, before returning to Carinhanha and travelling on to Salvador, where they arrived at the end of the year.

In February 1819 the party travelled to Piaui, Oeiras, where they arrived on May 3rd, and then moved on to São Gonçalo do Amarante (15th May), where Martius became seriously ill. By this time Spix had contracted the schistosomiasis from which he eventually died seven years later. In June 1819 they were in Maranhão to replenish funds and supplies. They sailed down the Rio Itapicuru to São Luis, leaving on July 20th and collecting specimens at several places en route to Belém. They left Belém on August 21st for a voyage up the Tocantins to Breves, passing through Gurupá, Porto de Moz on the Rio Xingu, and Santarém, arriving at the mouth of the Rio Negro on October 22nd and finally at Tefé on November 26th.

In Tefé the two friends split up, Spix left for Solimões and visited Tabatinga before returning to Manaus in February 1820. Martius sailed from Tefé up the Rio Japorá, returning to Manaus in March, where they reunited. Soon they were again in Belém, and at the end of 1820 they were back in their hometown of Munich, where von Martius was received with honor. He was made a member of the Royal Bavarian Academy and second conservator of the Botanic Garden of Munich.

Among von Martius' many orchid collections we find: at the herbarium in Paris, Sobralia liliastrum Lindl.; in Belgium (Meise), Campylocentrum tenue (Lindl.) Rolfe, Acianthera ochreata (Lindl.) Pridgeon \& M.W. Chase, Acianthera rupestris (Lindl.) F. Barros, Anathallis articulata (Lindl.) Luer \& Toscano, and Pabstiella hymenantha (Lindl.) Luer; and in Kew Aspidogyne foliosa (Poepp. \& Endl.) Garay, Brassavola martiana Lindl. (Fig. 25), Bulbophyllum napellii Lindl., Campylocentrum micranthum (Lindl.) Rolfe, Campylocentrum tenue (Lindl.) Rolfe, Dichaea muricata (Sw.) Lindl., Gomesa flexuosa (Lodd.) M.W. Chase \& N.H. Williams, Gomesa martiana (Lindl.) M.W.Chase \& N.H.Willias (Fig. 26), Gomesa ramosa (Lindl.) M.W.Chase \& N.H.Williams, Habenaria brevidens Lindl., Habenaria hexaptera Lindl., Habenaria imbricata Lindl., Habenaria mystacina

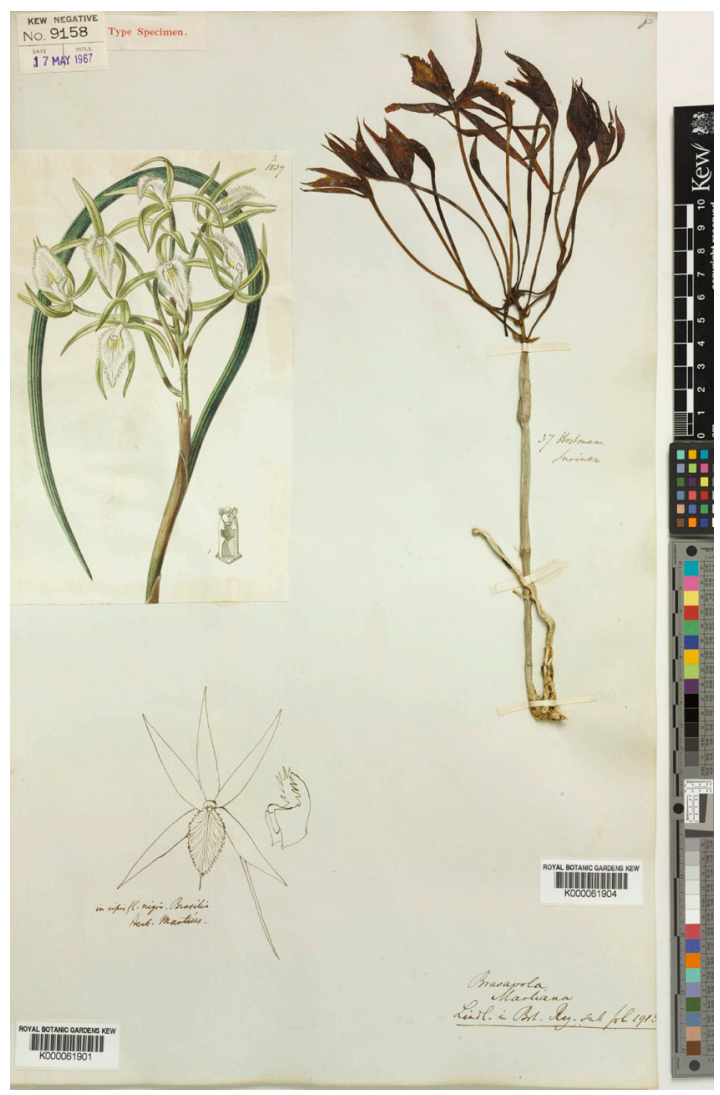

FIgURE 25. Brassavola martiana Lindl. Type specimen at Herbarium Kew, specimen \#000061901.

Lindl., Habenaria obtusa Lindl., Habenaria quadrata Lindl., Laelia caulescens Lindl., and Specklinia grobyi (Bateman ex Lindl.) F. Barros.

Mimosa spixiana Barneby in the Fabaceae, Banisteria spixiana Mart. ex A.Juss. in the Malpighiaceae, Calyptromyrcia spixiana O.Berg in the Myrtaceae, and many others were named in honor of Johann Baptist Ritter von Spix. Carl Friedrich Phillip von Martius is remembered in the names of the following orchid species: Bletia martiana (Lindl.) Rchb.f., Brassavola martiana Lindl., Epidendrum martianum Lindl., Oncidium martianum Lindl., and Stanhopea martiana Bateman ex Lindl. as well as its variety bicolor Lindl. (Fig. 27).

In 1824 Von Spix and von Martius published a highly interesting account of their travels in Brazil, under the title Travels in Brazil in the years 1817-1820, undertaken by command of His Majesty, the King of Bavaria. This comprises three volumes of text and one 


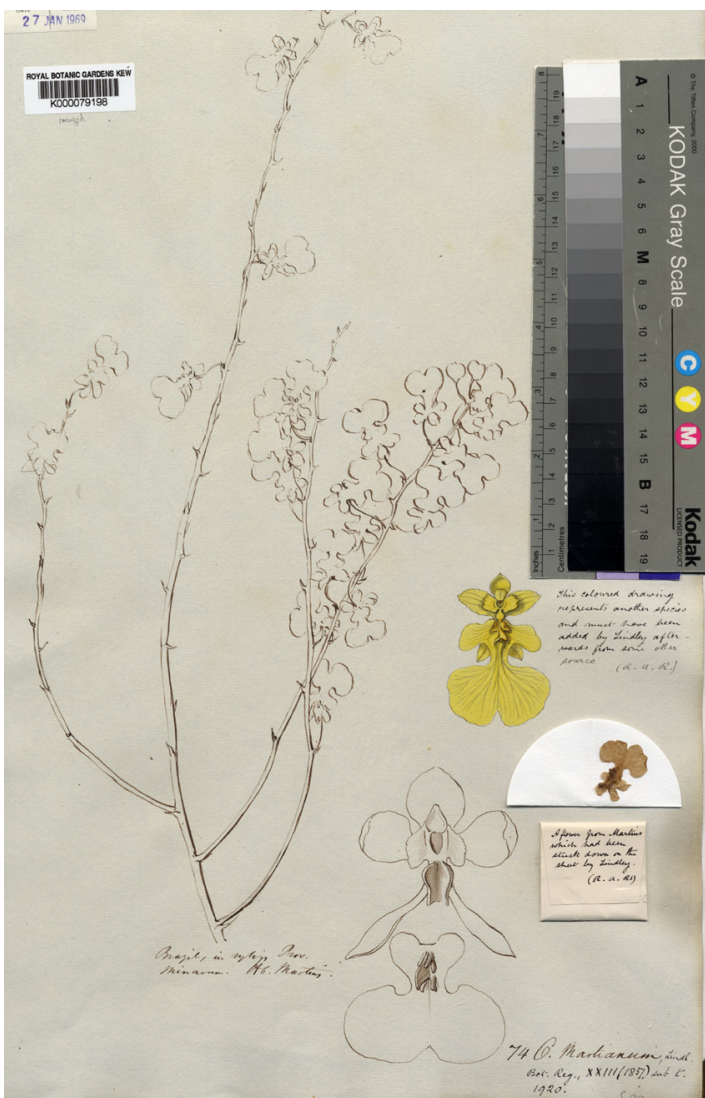

FIGURE 26. Drawing of the type specimen of Oncidium martianum Lindl. at Herbarium Kew, specimen \#000079198.

so-called Reiseatlas of illustrations, depicting objects of natural history, landscapes and scenes of daily life in Brazil (Fig. 28, A-B). This work gives a detailed account, not only of the expedition itself, but of the political, social and economic status of Brazil during those years. It is particularly useful in understanding the transition between the colonial period and the independence that would follow the proclamation of the Empire of Brazil under Dom Pedro I in 1822. The Reiseatlas is a treasure-chest of vivid images of the Brazilian landscape, its exuberant nature and its melting pot of races and cultures, which has imposed its mark on Brazilian society up to the present. Sadly, von Spix died during the preparation of the second volume, but von Martius finished its publication using in part von Spix's notes.

But undoubtedly, von Martius' publication of his Flora Brasiliensis was the most important achievement

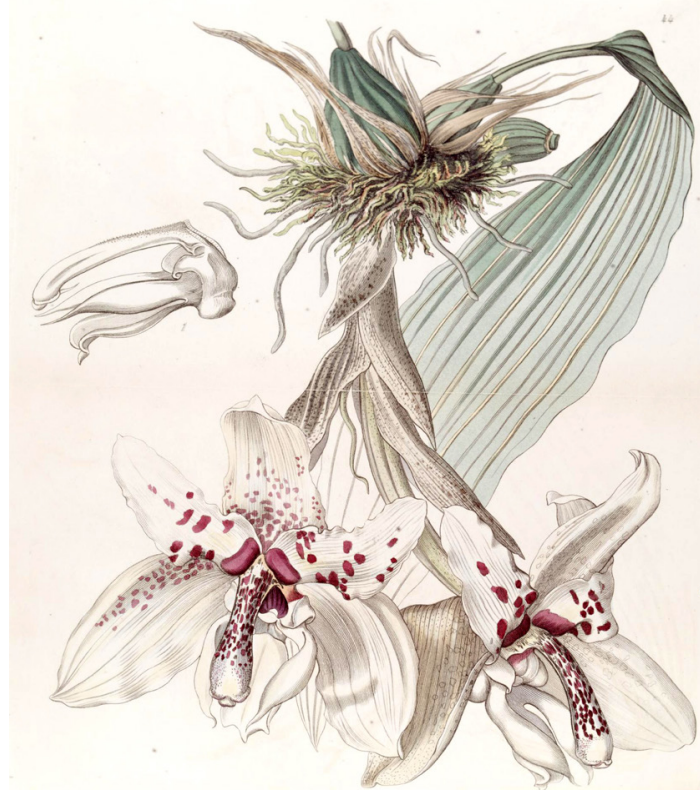

FIGURE 27. Stanhopea martiana var. bicolor Lindl. Edwards's Botanical Register 29: t. 44. 1843.

of the Bavarian expedition to Brazil. Publication began in 1840 as a joint effort by von Martius and Stefan Endlicher. It was completed in 1906, comprising a total of 10,376 pages in 130 fascicles, distributed in 40 parts and 15 volumes, describing and illustrating 22,767 species of Brazilian plants. Von Martius completed 46 of the 130 fascicles before his death in 1868 , the work being continued by August Wilhelm Eichler and Ignatz Urban as main author-editors. The last volume to be published (numbered volume III, parts IV, V and VI) was the treatment of the Orchidaceae (1893-1906), prepared by Alfred Cogniaux. We will read about this work in a later part of this study.

\section{Johann Baptist Emanuel Pohl and Giuseppe Raddi}

Johann Christian Mikan (1769-1844), a professor for Zoology and Botany at the University of Prague, had been chosen as the main botanist for the expedition. Unfortunately, after less than a year, in June 1818, and having made important collections (no orchids however!) in the province of Rio de Janeiro, Mikan was ordered to return to Vienna and to accompany those collections to a special museum that had been established to house the products of the Brazilian expedition. In Mikan's company the botanical illustrator Johann Buchberger, 


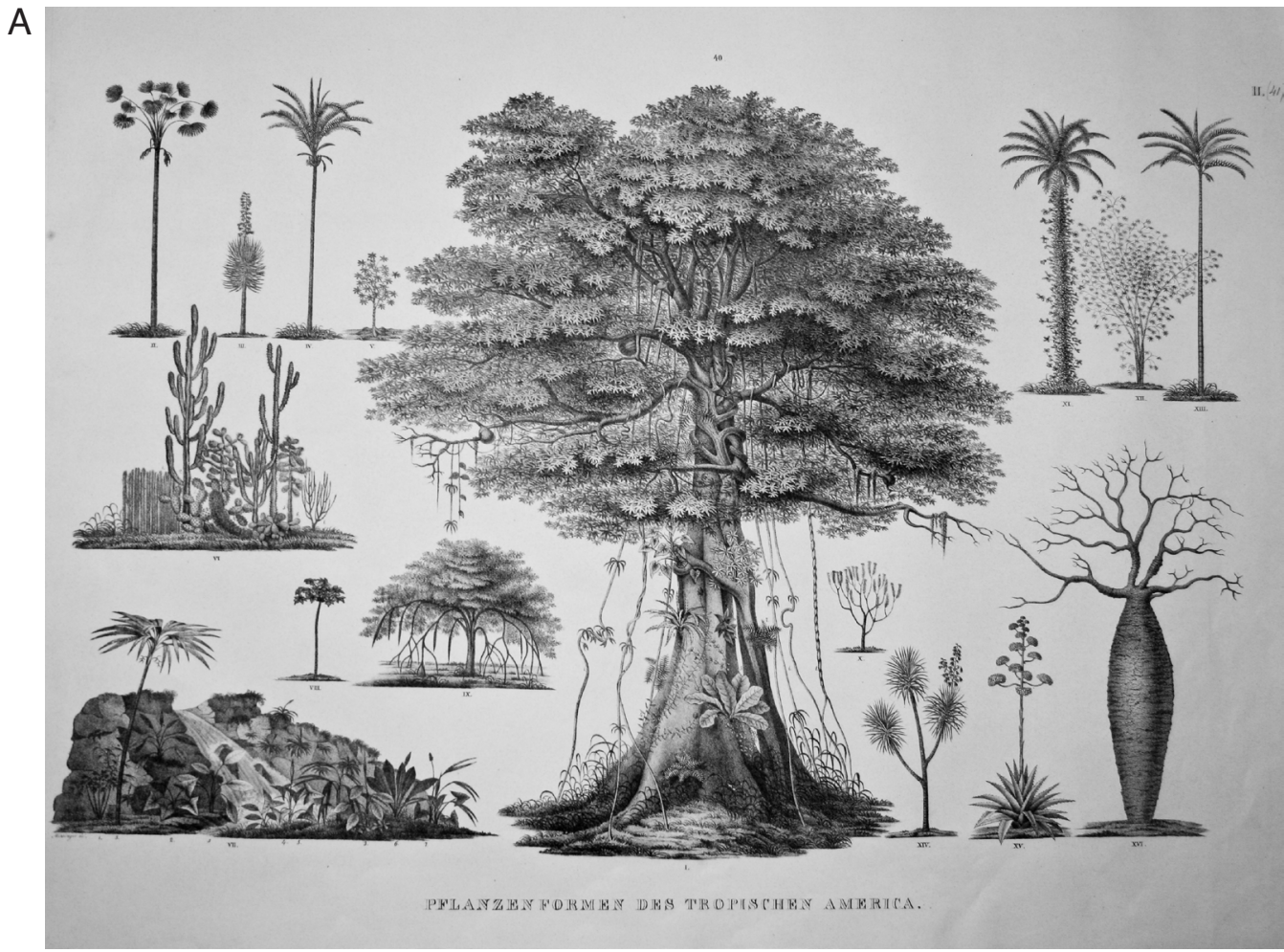

B

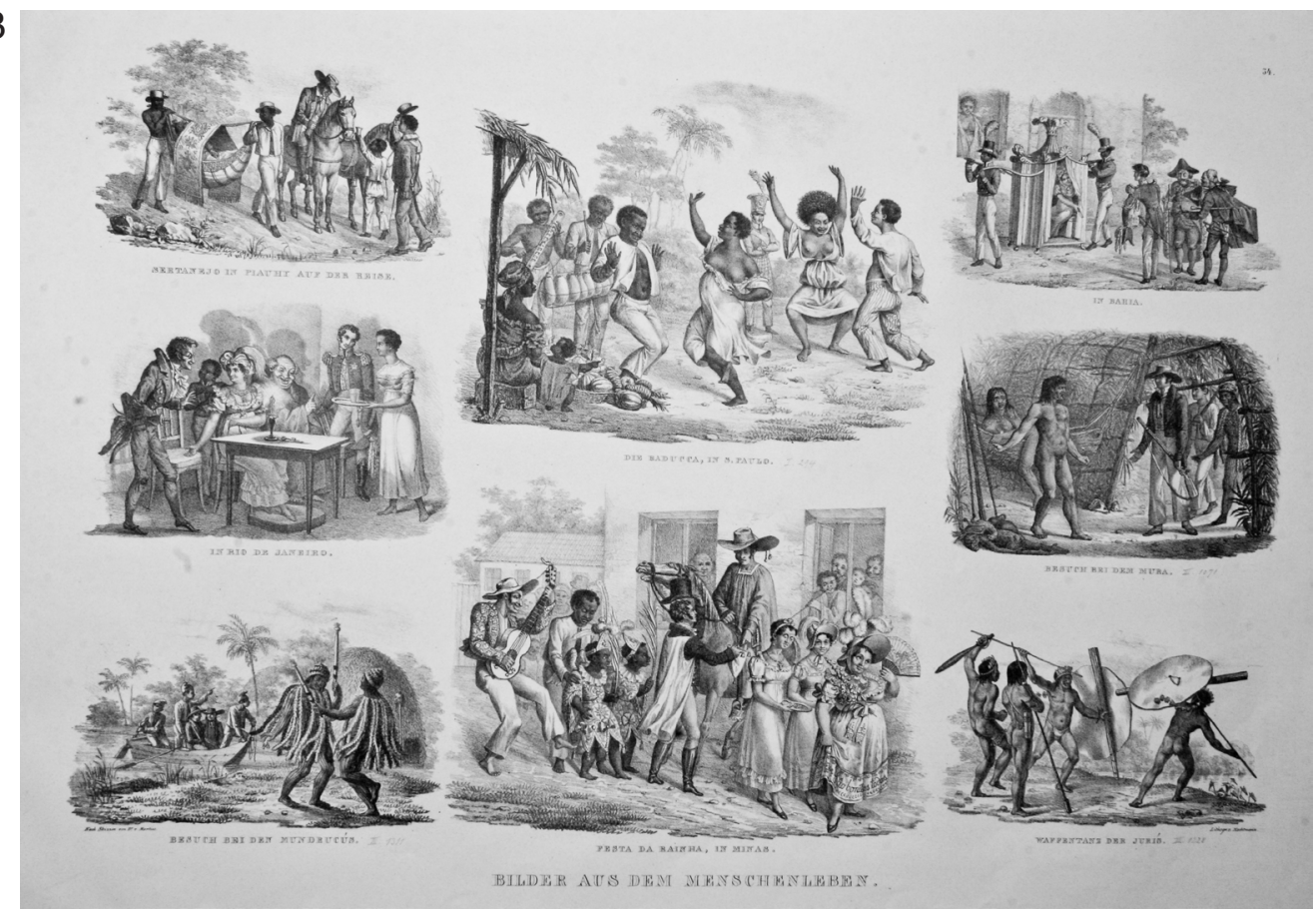

Figure 28. A. Forms of plants in tropical America. In v. Spix \& v. Martius, 1824, Vol. 3, Reiseatlas, p. 75. B. Scenes of Brazilian life. In v. Spix \& v. Martius, 1824, Vol. 3, Reiseatlas, p. 65. 
who had suffered a serious accident, also returned to Europe. The Italian botanist Giuseppe Raddi and the landscape painter Thomas Ender travelled with them. From then on, Johann Baptist Emanuel Pohl (17821834) (Fig. 29), previously in charge of mineralogy, was put in charge of all botanical aspects of the expedition. In this post he would explore the interior of Brazil, especially the Provinces of Minas Gerais, Goias, Bahia and the province of Rio de Janeiro as far as the District of Ilha Grande.

Pohl was born in Politz, in north-western Bohemia in the present day Czech Republic. He studied in Prague and graduated as Doctor of Medicine in 1808. He soon gained a reputation in several branches of natural history and was thus selected as one of the scientists to accompany Archduchess Maria Leopoldina to Brazil, on the occasion of her marriage to Dom Pedro I in 1817.

During the last months of 1817 and early 1818 , Pohl explored the province of Rio de Janeiro as far as Villa de Ilha Grande. But once he took over Mikan's position, he started on his long journey, beginning in September 1818 from -as one could have guessedLangsdorff's Fazenda Mandiocca. From Mandiocca he travelled for fifteen months in a westerly direction to the village of Villa Bõa, the capital of the province of Goias, where he took canoes down the River Maranhâo (Fig. 30). He travelled along the border of the provinces of Goias and present-day Tocantins, returned to Villa Bõa and then went northeast through Minas Gerais towards Bahia until September 1820, navigating the River Jequitinhonha. The impassable falls of Salto Grande made him turn back before reaching the mouth of the river. In December 1820 he reached Villa Rica in Minas Gerais, where he visited his friend Baron von Eschwege. He then passed again through Mandiocca in February 1821 (Langsdorff was at that time in Europe) and arrived finally in Rio on 28th February 1821. At the end of that year he was back in Vienna, his health weakened by the severe conditions of his journeys. Pohl's botanical collections -over 4,000 specimens of Brazilian plants- were housed with the rest of the expedition's collections in the Brazil Museum of Vienna. These collections included two live 'human specimens' of Botocudo tribespeople. The woman died soon after arriving; the man was eventually returned to his homeland. After his return to Europe, Pohl was appointed as a curator at the Vienna Natural History

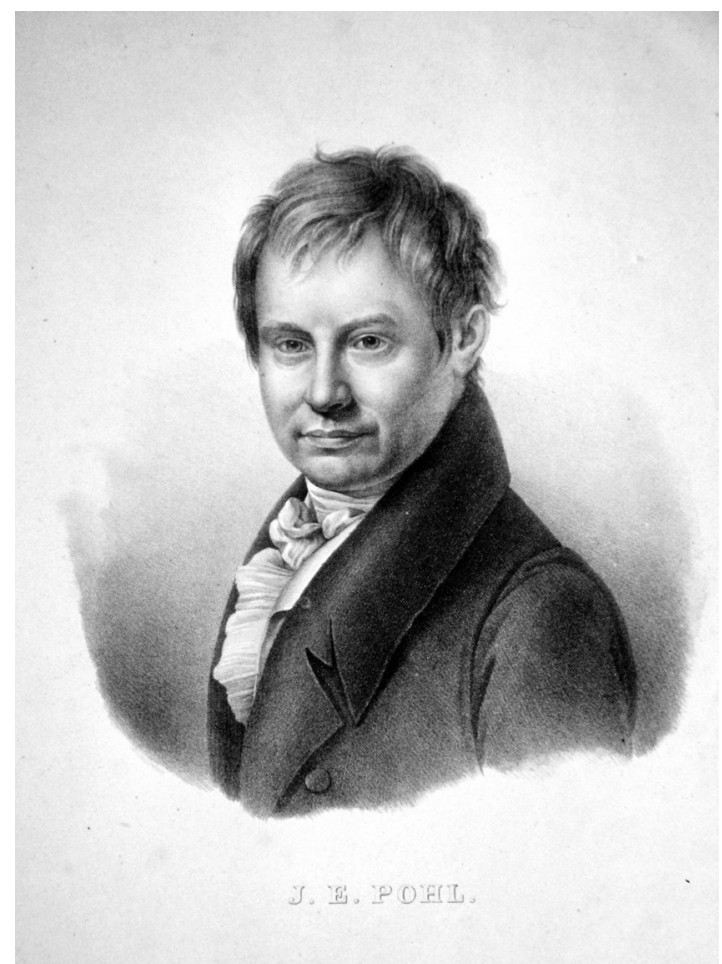

Figure 29. Johann Baptist Emanuel Pohl (1782-1834). Lithograph by unknown artist, ca. 1830.

Museum and the Brazil Museum of Vienna, positions he would hold until his death.

In 1832 Johann Baptist Pohl published the first volume of his travel journal, Reise im Innern von Brasilien (= Journey through the interior of Brazil). A small Atlas with three illustrations of Brazilian landscapes was part of this first volume (Fig. 31). The second volume was published posthumously in 1837 , by order of the Emperor Francis I.

Pohl makes frequent mention of the exuberant vegetation of the regions through which he travels and the masses of epiphytic and parasitic plants he observes on the jungle trees. He mentions, however, only one orchid, Epidendrum vanilla L. (= Vanilla mexicana Mill.): The trees showed themselves often tightly embraced by Vanilla (Epidendron Vanilla), in Portuguese: Baonilha. The pods of these plants are a favorite dish for bats. At the present season the plants were however without flowers or fruits (Pohl, 1832: 416-417).

Amongst Pohl's botanical collections we find the following orchid specimens: Cranichis scripta 

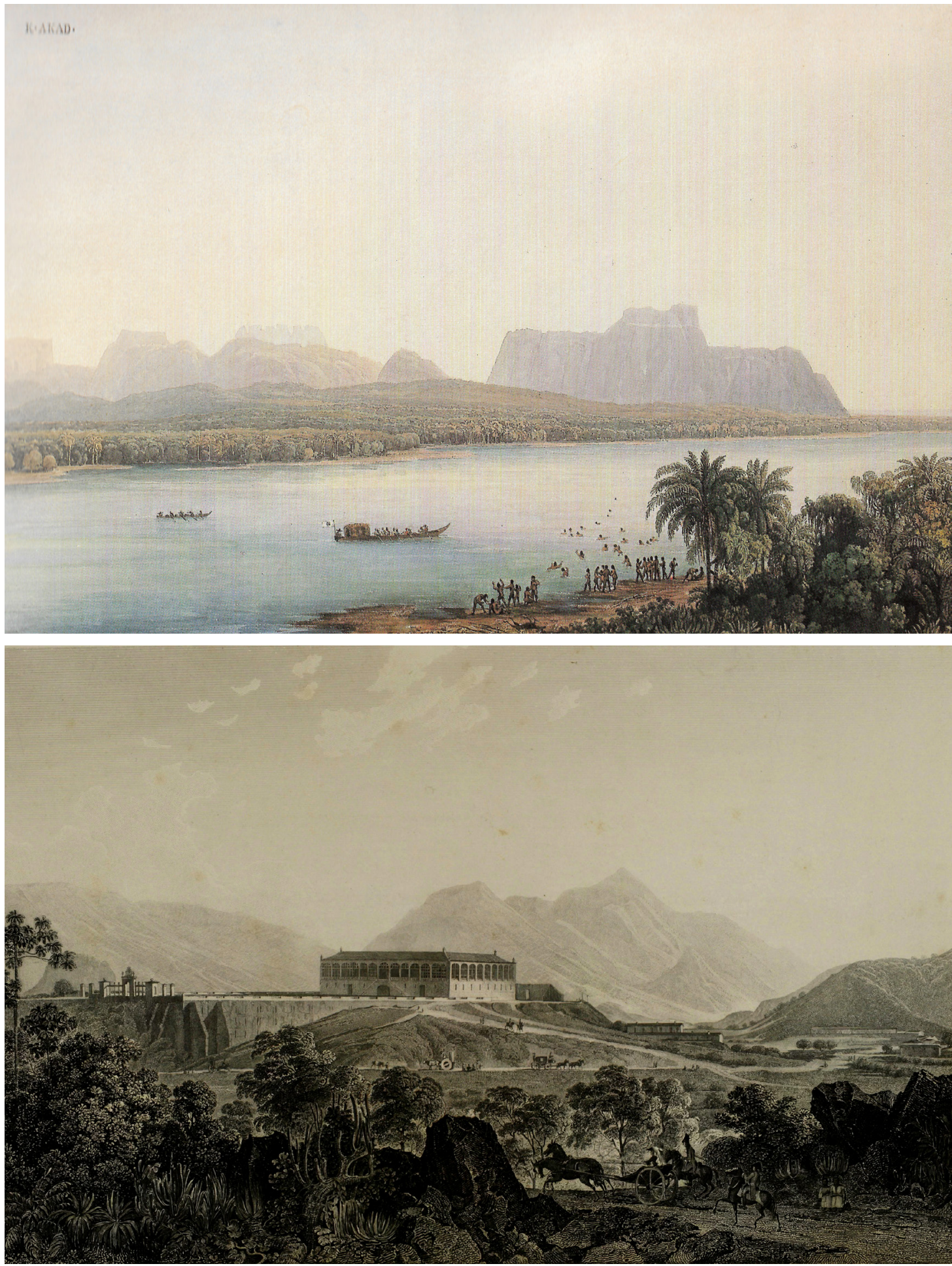

FiguRE 30 (top). River Maranhâo. Watercolor by Thomas Ender from an original drawing by J.B. Pohl. FIGURE 31 (bottom). Royal Palace at Sâo Cristovâo. Illustration in Pohl's Atlas, 1832, p. 4. 


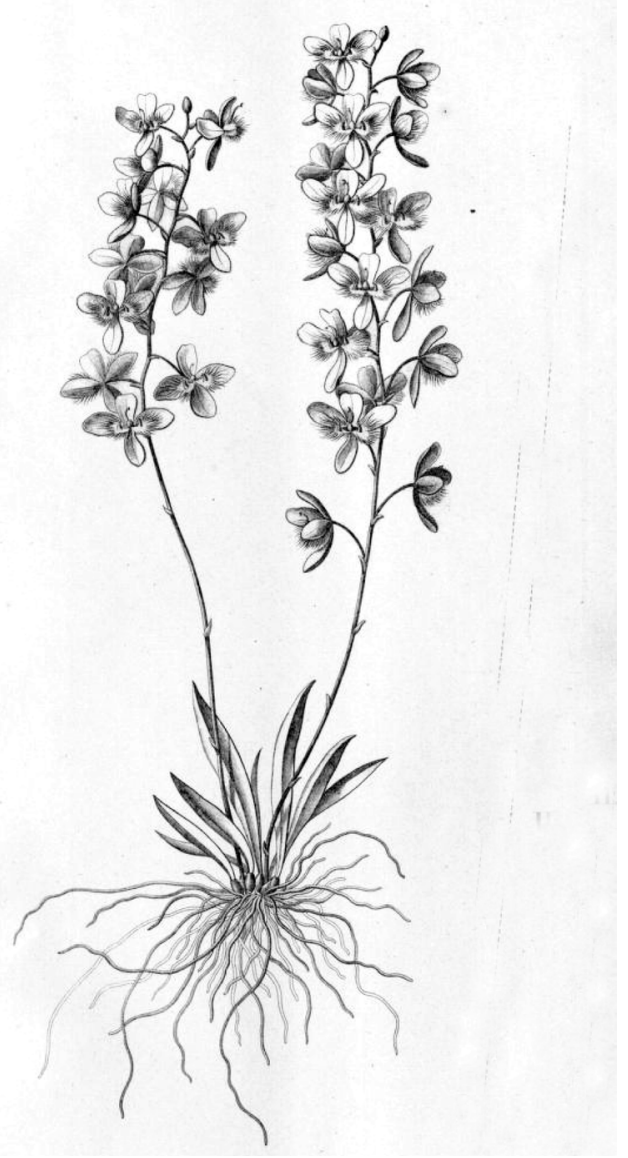

FIgURE 32. Dipteranthus corniger Cogn. Plate 93 (fragment) in Flora Brasiliensis, volume 3, part 6, 1904-1906.

Kraenzl., Pelexia trachyglossa (Kraenzl.) Pabst, and Skeptrostachys paranahybae (Kraenzl.) Garay (Oakes Ames Orchid Herbarium); Diptheranthus corniger Cogn. (Fig. 32) (Herbarium Meise); and Habenaria goyazensis Cogn. (Herbarium Vienna).

Cogniaux dedicated Oncidium pohlianum (Fig. 33) to him.

Giuseppe Raddi (1770-1829) (Fig. 34) was born in Florence, Italy, into a modest family. An early interest in botany led him to move from an apprenticeship as a druggist in his hometown to a position as an assistant to Professor Ottavio Targione Tozzetti, at the Spedale Santa Maria Nuova, and later at the Botanical Garden in Pisa. Subsequently, he received a proposal to become an assistant to the renowned physician and botanist Attilio Zuccagni, director of the Museum of Natural History in Florence. He worked for over ten

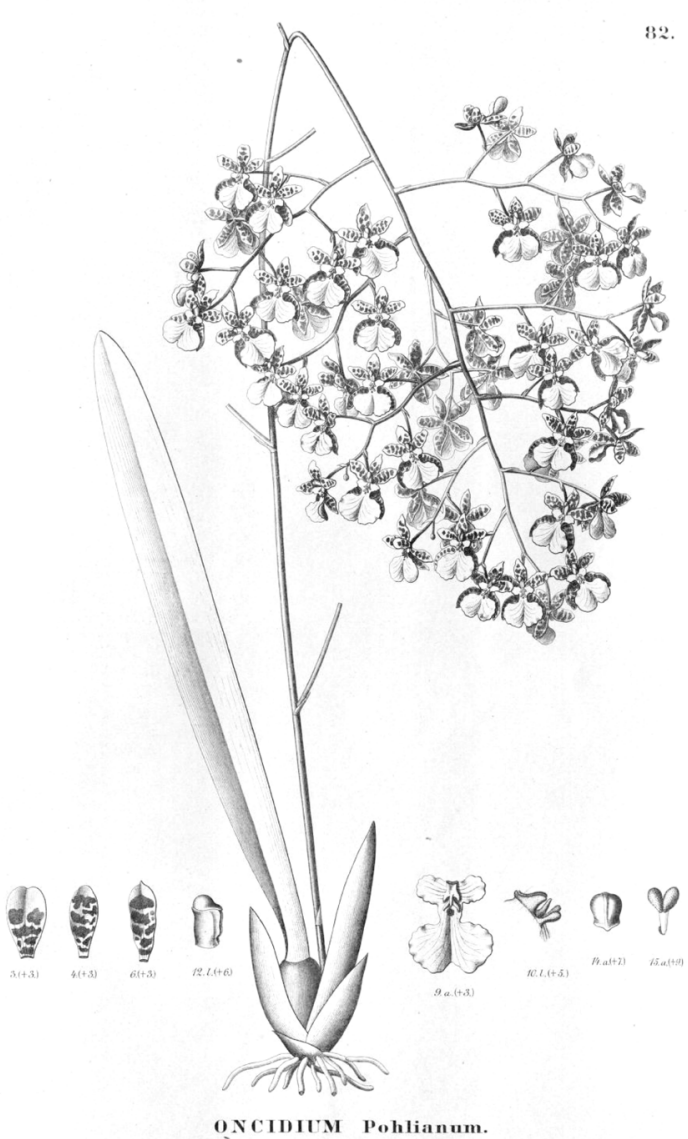

Figure 33. Oncidium pohlianum Cogn. Plate 82 in Flora Brasiliensis, volume 3, part 6, 1904-1906.

years at the Museum, with an interlude during the French invasion, and in 1817 was invited to take part in the Austrian Expedition to Brazil.

He sailed in the company of the Archduchess Maria Leopoldina, arriving in Rio de Janeiro in November 1817 , and immediately began botanical collections, mainly in the Rio de Janeiro area, including Serra d'Estrela and Serra dos Orgaos. He collected together with Langsdorff, and it is said that he made excursions with Charles Gaudichaud-Beaupré during the latter's short stay in Rio in December 1817-January 1818 (Baldini \& Guglielmone, 2012), although no specimens by Gaudichaud have been recorded from that period.

Unlike other members of the expedition, such as the Germans Martius, von Spix and others, Raddi's financial means were very limited. Furthermore, he was alone and did not have any assistants to help him 


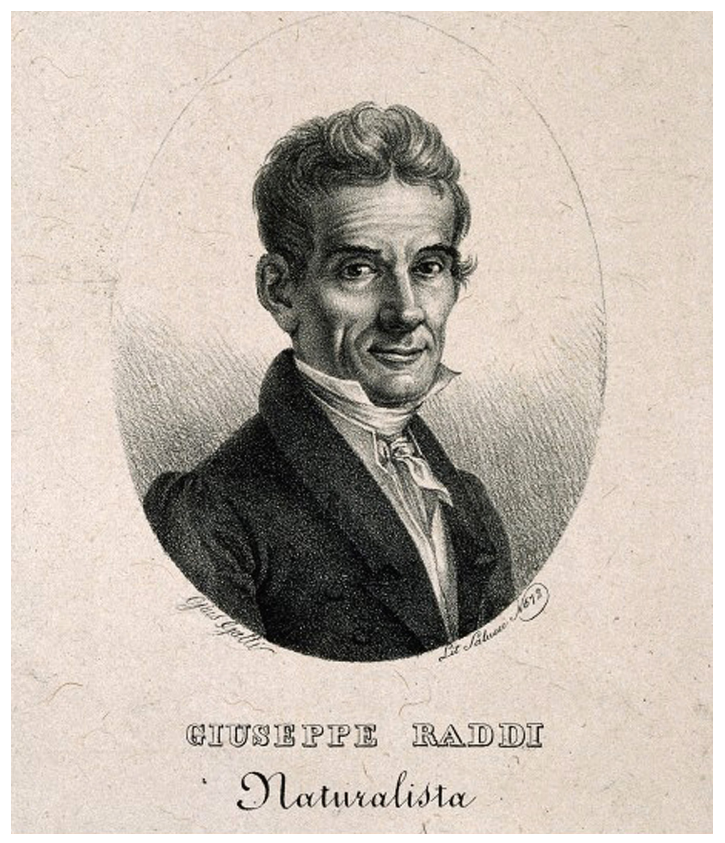

FIgURE 34. Giuseppe Raddi (1770-1829). Litograph by G.

Galli. Courtesy of Rudolf Jenny.

in the field. Life in Rio de Janeiro was too expensive to allow him to employ impromptu local assistants. Raddi tried in vain to get more funding from Tuscany for a prolonged stay in Brazil and was forced to return to Italy, leaving Rio de Janeiro on June 1 1818, together with Professor Mikan and Thomas Ender (Baldini \& Pignotti, 2018: 7-8).

It is not clear how many plants Raddi collected in Brazil. In a letter to the Grand Duke of Tuscany, Raddi wrote that in Brazil he collected 3000-4000 plants, the seeds of 340 species, 3300 insects and several fishes, reptiles and birds (Baldini \& Guglielmone, 2012). He described several new species based on this material, among them a new orchid, Cyrtopodium glutiniferum Raddi, published in Modena in 1823 (Fig. 35). The original botanical collection was transferred to Pisa from Florence after Raddi's death.

In 1824 Grand Duke Leopold II of Tuscany organized a scientific expedition to Egypt, led by the famous Ippolito Rosselini, professor of oriental languages of the University of Pisa. Raddi was selected to accompany the expedition as naturalist, and once in Egypt, he collected plants along the Nile, getting as far as the first cataract. On his way back, he fell ill with dysentery and died on September 8th 1828 on the island of Rhodes, en route to Florence.

Grand Duke Leopold II bought Raddi's private herbarium and donated it to the University of Pisa

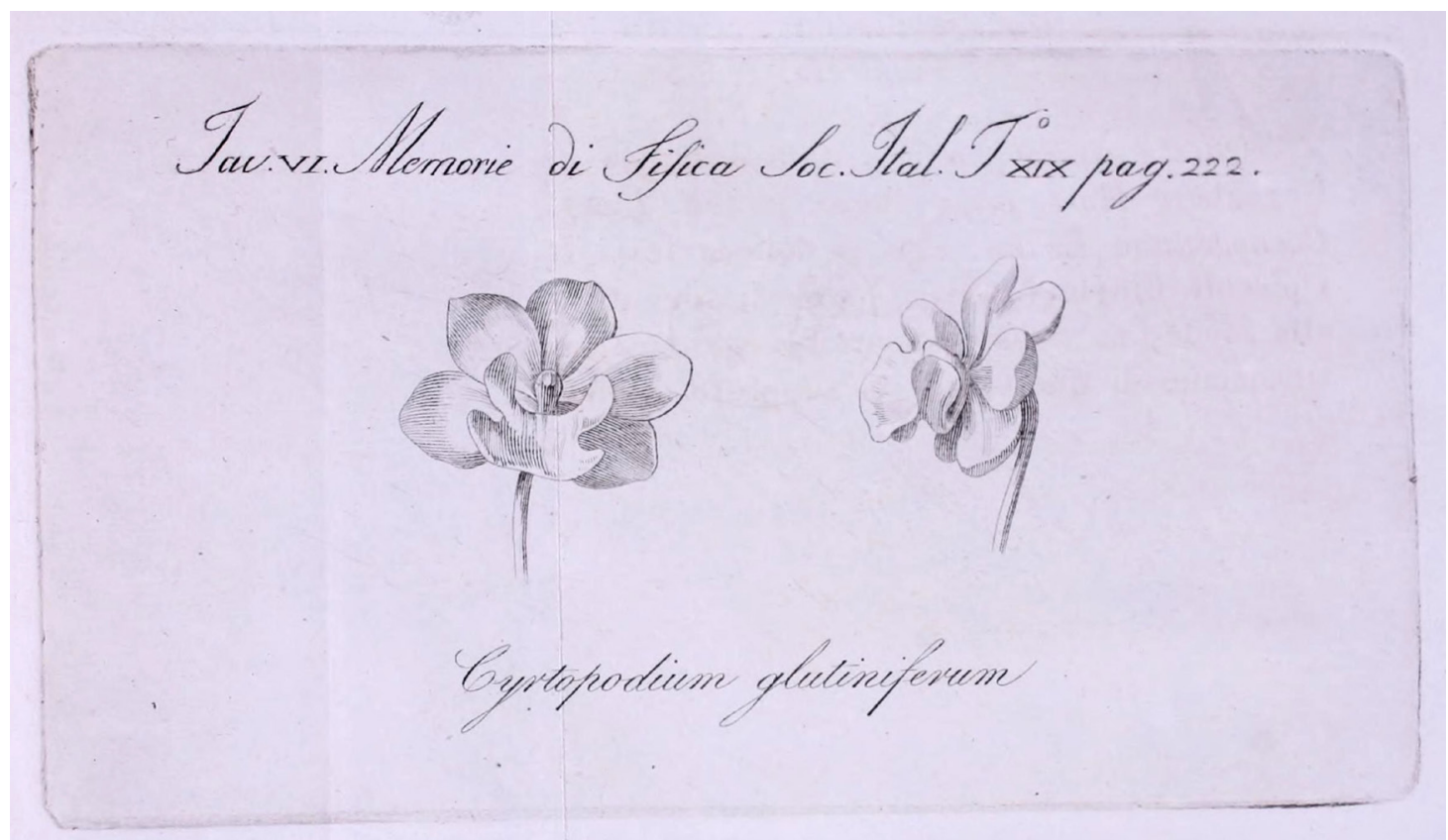

FIgURE 35. Illustration by Raddi of Cyrtopodum glutiniferum, in Memorie di Matematica e di Fisica della Società Italiana delle Scienze Residente in Modena, Parte contenente le Memorie di Fisica, 1823. 


\section{The Brazilian landscapes of Thomas Ender}

The contribution of Thomas Ender (1793-1875) (Fig. 36) is of great importance to the understanding of the social and cultural circumstances encountered by the expedition upon its arrival in Rio de Janeiro. Ender painted a portrait not only of the city and its surrounding landscape, but of Brazilian society in the era of slavery, which he approached from a very critical point of view, interesting himself especially in the diverse nationalities of the Brazilian slaves (Fig. 37).

Ender was born on the outskirts of Vienna into a humble household. Together with his twin brother, Johann, he entered the Vienna Academy of Arts in 1806 , to study historical painting. He soon changed to landscape painting, which he learned under Professor Laurenz Janscha and, after Janscha's death, Professor Joseph Mössner. In 1816 he was distinguished with the Grand Prize of the Academy. He travelled through Austria and Italy, learning and improving his techniques, and in 1817 he was chosen by Austrian Prime Minister Prince Clemens Metternich as a member of the Austrian Expedition to Brazil.

Ender sailed to Brazil from the port of Trieste with the first group of scientists on the frigates Austria and Augusta, in the company of von Martius, von Spix and Professor Mikan in April 1817, arriving in Rio de Janeiro on July 14th.

He soon set out to explore the region around the Brazilian capital, and Langsdorff's fazenda Maniocca was for him, as for so many others, an obligatory visit. One of his longest excursions took him to Sâo Paolo with von Martius and von Spix. From this journey we have from him a beautiful painting of the Vale das laranjeiras (the valley of the orange growers) (Fig. 38). He extensively documented Rio de Janeiro and the Vale do Paraíba, where coffee growing was starting. After his return to Rio, he dedicated himself to capturing beautiful scenes of the capital, its squares and churches, its people and daily life (Fig. 39, A-B) and the park and waterfall of Tijuca (Fig. 40).

Thomas Ender was a more accomplished painter of landscapes than any other traveller of this period. In his works one can appreciate his detailed observation of vegetation, his careful treatment of scenes and perspectives and his magnificent treatment of urban

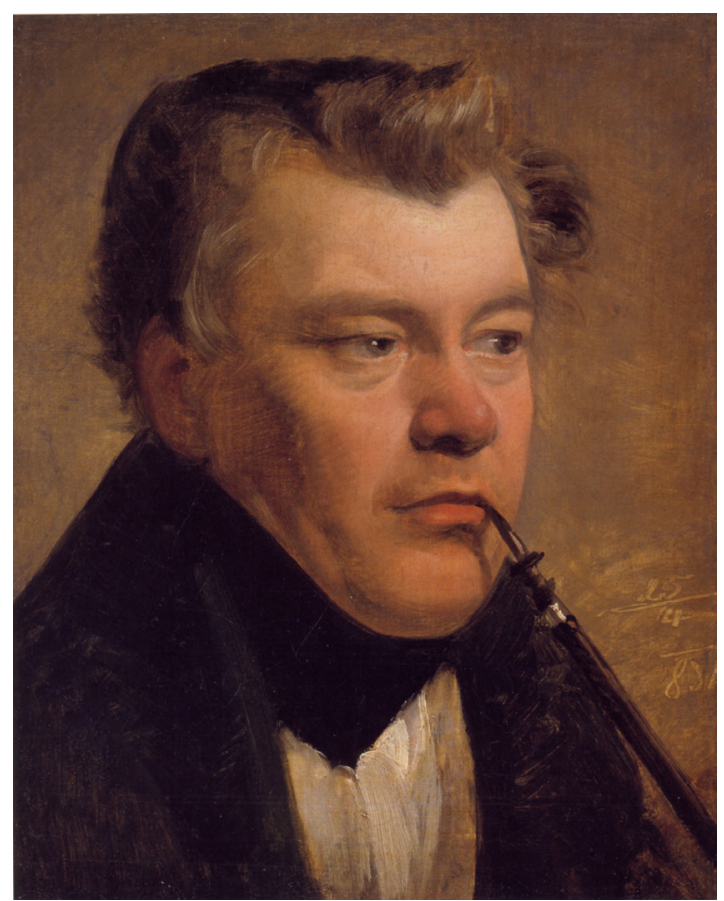

FIgure 36. Thomas Ender (1793-1875). Portrait by Friedrich von Amerling. Österreichische Galerie Belvedere.

space from different points of view. According to Texeita Leite (1988) "Thomas Ender practised the techniques of oil painting and watercolor, being an outstanding master of the latter. As a landscape painter, he worked not only in his native country and Brazil, but also in Turkey, Greece and other regions. Of obvious interest for us is that part of his work produced in Brazil, in Rio de Janeiro, Sâo Paolo and the surroundings of both cities. His designs and watercolors are of extreme sensibility, traced, drawn and blotted with outmost elegance and hability. They retain all the emotion felt by the artist at his first impression. Thus, Ender reveals himself as one of the major painters that visited Brazil in the first decades of the 19th century, and of the most noteworthy Austrian artists of his time".

On June 1st 1818 the Austria returned to Europe with Professor Mikan accompanying the natural history collections of the Austrian expedition. Ender, who was suffering from tropical diseases, decided to return to Vienna, too. He spent the next months on board sorting, indexing and listing his drawings. Upon his return, Ender delivered a total of 782 works 

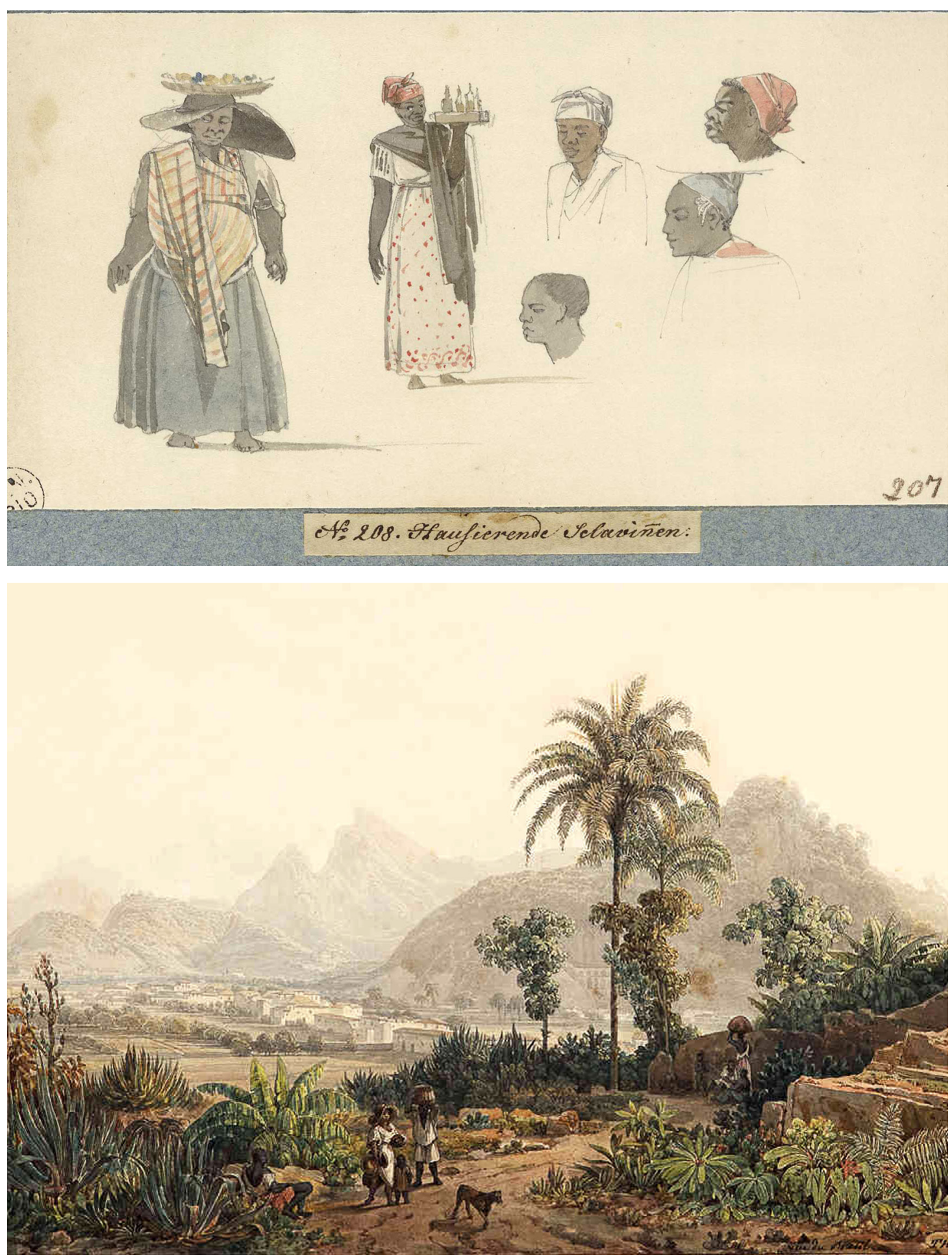

Figure 37 (top). Domestic slaves. Watercolor by Thomas Ender.

Figure 38 (bottom). Vale das laranjeiras, Sâo Paolo. By Thomas Ender. 
5. 1713 .
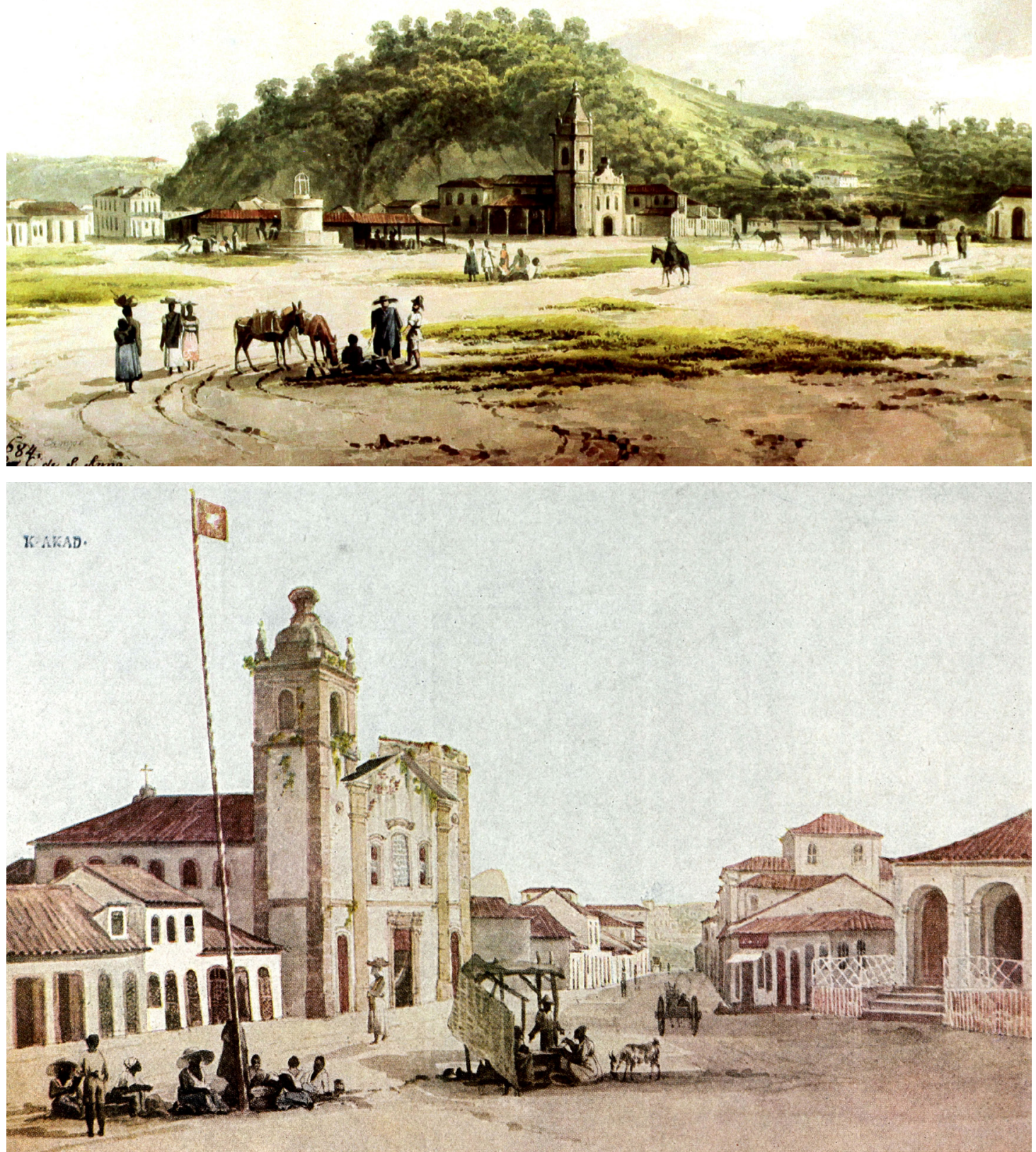

Figure 39. Paintings by Thomas Ender. A. Park of Santa Ana, Rio de Janeiro. B. Vale das laranjeiras, Sâo Paolo. 


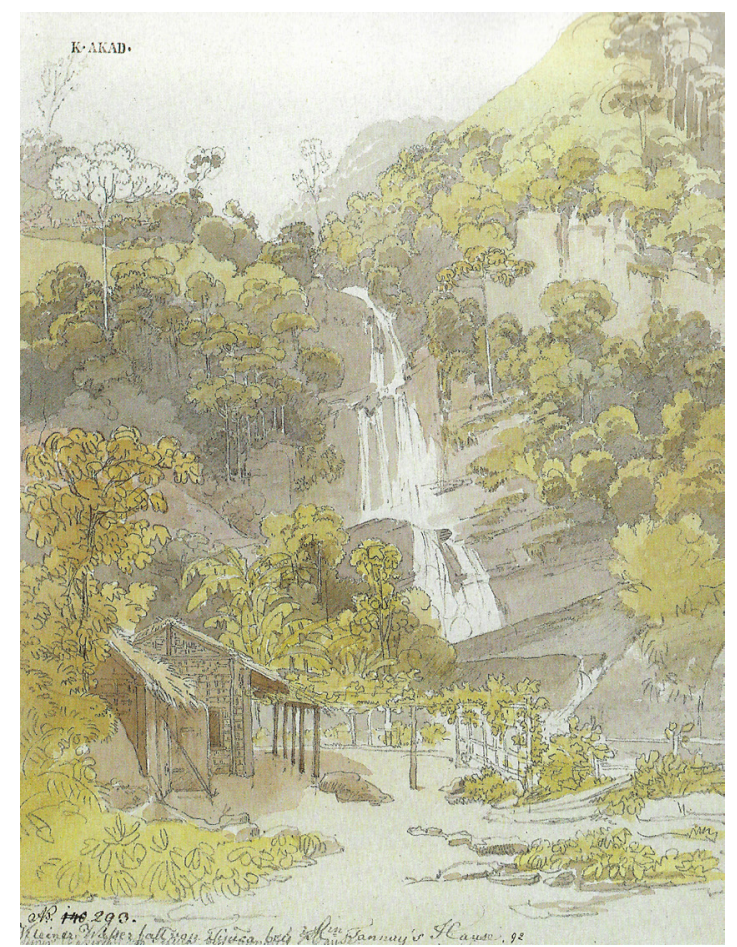

FiguRE 40. Small waterfall of Tijuca. Sketch by Thomas Ender.

to the Imperial government. These watercolors and sketches, which constitute the majority of his work in Brazil, remain one of the most beautiful and evocative sources of information on Brazilian colonial life and society. Along with Jean-Baptiste Debret and Johann Moritz Rugendas, Ender stands out as one of the greatest documentarians of Brazil's past.

After his return to Vienna, Ender travelled with Metternich to Rome, where he stayed on an Imperial grant until 1823. The year 1824 saw his appointment to the Vienna Academy. From 1837 to 1851 Thomas Ender was Professor at the Vienna Academy of Arts and created a series of sets of landscapes, which where often engraved in steel by English artists.

Thomas Ender combined his artistic talent with a great interest in geographic and topographic details, a feature that is particularly noteworthy in his Brazilian landscapes. He was thus a perfect illustrator in an era in which many painters endeavoured to document the world and nature fully and realistically, much in line with the philosophy of Alexander von Humboldt.

\section{Heinrich Carl Beyrich}

The son of the gardener Heinrich Beyrich, Heinrich Carl Beyrich (1796-1834) was born in the German city of Wernigerode, where he finished his secondary studies before going on to study Botany at the University of Göttingen and serve an apprenticeship at the Botanical Garden of the University. After finishing his studies he continued working as a gardener and landscaper at the Royal Garden in Tübingen and the Imperial Garden of Schönbrunn in Vienna. The year of 1819 saw him in Paris in the company of Alexander von Humboldt. He then went on to England on Humboldt's recommendation. At von Langsdorff's invitation, he was commissioned by the Prussian Government for a botanical journey to Brazil to collect plants for the Botanical Garden of Berlin.

Beyrich landed in the first days of June 1822 in Rio de Janeiro, where he stayed for several weeks. He then travelled to the Serra da Estrela, Langsdorf's Fazenda Mandiocca, Serra dos Orgaos, Serra da Tingua, Tocaia, Pilar, Morambaia and Lagoa da Saquarema, all in the Province of Rio de Janeiro. In July 1823 he returned to Germany, having collected over 400 species of living plants for Berlin's Botanical Garden and hundreds of herbarium specimens, many of which were new to science. In the final years of his life he was described as of middle stature, usually walking somewhat bent forward, with a dreamy inquisitive attitude, thin in feature, eyes easily lighted up, and made to glow with pleasure, a hooked nose, betraying his great courage and perseverance (Anonymous, 1846-47:101).

Among his Brazilian collections we find a number of specimens of Orchidaceae, such as Habenaria secunda Lindl., Stelis miersii Lindl., Stelis papaquerensis Rchb.f., Ascolepis brasiliensis (Kunth) Benth. ex C.B.Clarke, Habenaria helodes Rchb.f., Habenaria achnantha Rchb. f., and Habenaria modestissima Rchb.f.; Cymbidium stapelioides [= Promenaea stapelioides (Link \& Otto) Lindl.] (Fig. 41), a new species brought by Beyrich from Rio de Janeiro, was published by Heinrich Friedrich Link and Friedrich Otto in their beautiful work about selected plants at the Berlin Botanical Garden, Icones plantarum selectarum Horti Regii Botanici Berolinensis cum descriptionibus et colendi ratione (1820-1828). Pleurothallis beyrichii Rchb.f. and Galeandra beyrichii Rchb.f., also new species collected by Beyrich, were dedicated to him.

In 1833, after having been defeated by a rival 


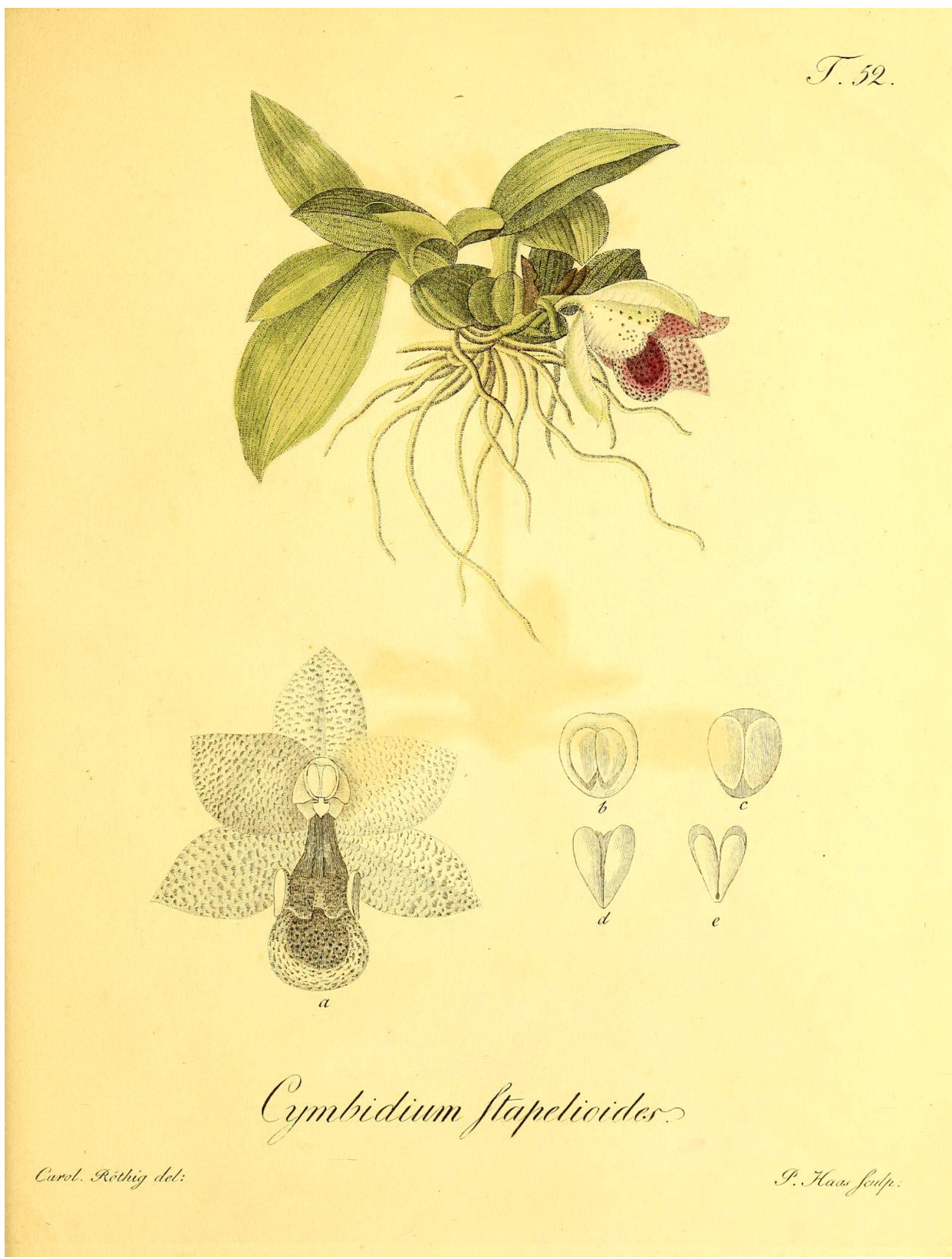

FIgURE 41. Cymbidium stapelioides Link \& Otto. Plate 52 in Link's Otto’s Icones plantarum selectarum Horti Regii Botanici Berolinensis cum descriptionibus et colendi ratione. 
candidate for the position of curator of the Imperial Garden at Berlin, he embarked for the United States, again on a botanic journey commissioned by the Prussian government. While accompanying a military expedition to Fort Gibson, Oklahoma, he died there from cholera in 1834.

\section{The Langsdorff Expedition to the interior of Brazil}

Of all scientific expeditions to the New World, seldom had one been as carefully prepared as that undertaken by Baron von Langsdorff in the early 1820 s. After having purchased his Fazenda Mandiocca near Rio de Janeiro in 1816, where he grew coffee and root crops using slave labor, the next step in Langdorff's plans was to replace slaves with European colonists. To this end, he travelled to Europe in 1820, promoting the idea of European immigration vigorously. He published two pamphlets advocating settlement in Brazil, one in Paris in 1820 and the second at Heidelberg in 1821. These were the first works on the subject to appear in Europe (Barman, 1971: 74).

While in Saint Petersburg in June 1821, he presented the plan for a great scientific expedition to the interior of Brazil to Karl Nesselrode, the Vice-Chancellor of the Empire. His stated objective was to make scientific explorations, geographic discoveries, and studies of the little known produces of commerce and materials of all kingsdoms of Nature that could be gained to enrich the collections of the Empire. Two days later he was received by Tsar Alexander I (1777-1825)], who guaranteed his personal patronage of the initiative.

The expedition would last for fifteen years, including intervals and the different composition of its members, from 1821 to 1836, and cost the Russian Treasury almost three hundred and thirty thousand roubles (Banco do Brasil, 2010: 8). With the liberty to choose his route, almost unlimited time, and ample financial means, Langsdorff took his time in Europe assembling a group of specialists in various fields of science and buying the necessary equipment.

Ludwig Riedel (1791-1861) (Fig. 42) was to be the expedition's botanist. Riedel arrived in Brazil in advance of his future companions. Between 1821 and 1829 , as we will see shortly, he amassed an important herbarium of over 100,000 samples of 8,000 different species of plants. Néster Gavrílovitch Rubtsov (17991874), a graduate of the School of Navigation of the

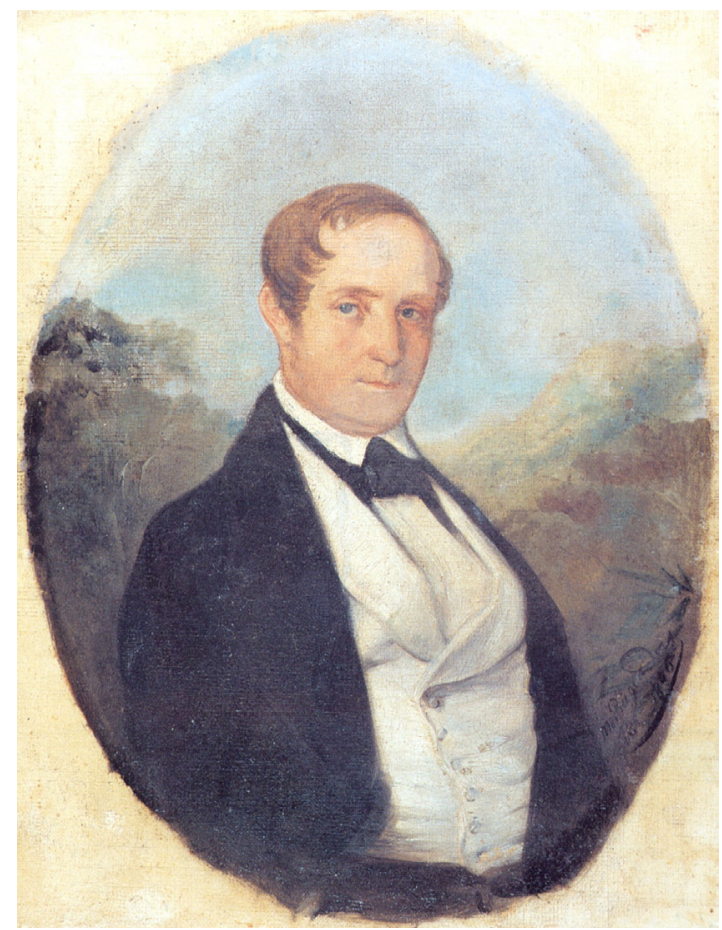

Figure 42. Ludwig Riedel (1790-1861). Portrait by Johann Moritz Rugendas.

Baltic Fleet, served as the expedition's navigator and became Langsdorff's right-hand man during the years of the expedition. He also arrived in Rio before Langsdorff, as the second member of the team, in February 1822. Twenty-eight excellent maps are preserved in Saint Petersburg, proof of Rubtsov's excellent cartographical work during the journey.

At the end of 1821 Langsdorff sailed from Bremen in a chartered ship carrying a group of eighty-five Germans he had contracted to settle on his fazenda. They arrived in Rio de Janeiro on March 6th 1822. In Langsdorff's company sailed Edouard Ménétries (18021861), who was the official zoologist. A disciple of the famous French naturalists G. Cuvier and P. Latreille, he was responsible for the zoological records until the summer of 1825, when he returned to Saint Petersburg with letters of recommendation written by Langsdorff. He became a collaborator of the Saint Petersburg Academy of Sciences and one of its corresponding members. Johann Moritz Rugendas (1802-1858), from a family of famous Bavarian painters, was to be the artist of the expedition between 1822 and 1824. He arrived with Langsdorff and Ménétries. 


\section{Ludwig Riedel}

Born in Prussia in late 1790, Ludwig Riedel, who possessed a talent for languages, had acquired considerable experience working as a horticulturist and botanist in several European countries. He was sent to Brazil as Langsdorff's deputy ahead of the main part of the expedition and occupied his time there collecting materials for remittance to Russia (Barman, 1971: 75-76). Prior to this Riedel had served in the Prussian army (1813-1815) and collected plants in the south of France (1816-1817).

Riedel landed in Ilhéus, Bahia, in February 1821, and started botanizing and touring. He established relations with groups of foreign settlers, which helped him to get to know the country. Riedel stayed in southern Bahia until early November 1822, and then sailed to Rio de Janeiro, where he arrived on November 15th. He immediately went to the Russian Consulate, where he was received by the vice-consul since Langsdorff was at his country house in Mandiocca. Riedel came into contact with Georg Wilhelm Freyreiss and with the German botanist Heinrich Carl Beyrich.

While Riedel was still in Bahia, Langsdorff set off on his first excursion, which explored as far as the town of Novo Friburgo. While little or none of this exploration was original in a geographic sense, the area investigated was scientifically mostly unknown. Returning to Rio de Janeiro in December 1822, the expedition found that, during its absence, Prince Regent Pedro had declared Brazil independent of Portugal and had himself crowned Emperor of the new Empire of Brazil, taking the name of Pedro I. Although Langsdorff quickly assured the new regime of the good will with which he [the Tsar] will receive this most important event, Alexander I did not recognize the Empire of Brazil for another five years (Barman, 1971: 76).

After visiting the main sights of the capital of the very recently declared Empire of Brazil, Riedel departed for Fazenda Mandiocca, where he finally met not only Langsdorff, but also Rugendas, Rubtsov and Ménétries, who were preparing to depart for the tropical jungle (Rodrigues de Moraes, 2012b: 187).

Although Langsdorff kept his position as Russian Consul General, the political and diplomatic uncertainties of the period probably made any prolonged absence from the capital unwise and may explain the quiescence of the expedition during 1823 .

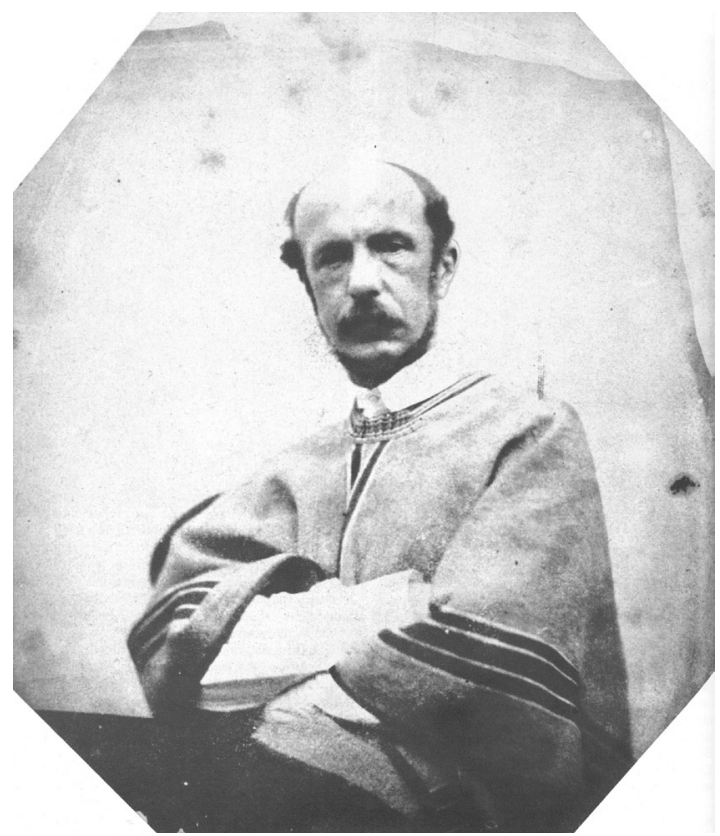

Figure 43. Johann Moritz Rugendas (1802-1858). Photograph by Franz Hanfstaengls.

Riedel used this time for further botanical collecting, using both Langsdorff's house in Rio and his property in Mandiocca as headquarters.

\section{Johann Moritz Rugendas}

Considered by far the most varied and important of the European artists to visit Latin America (Miles, 1996), Johann Moritz Rugendas (1802-1858) (Fig. 43) had just graduated from the Munich Academy of Arts and had little professional experience when he landed in Rio de Janeiro on the Doris von Bremen in 1821. The turning point in his career was his appointment by Langsdorff as the draftsman of the expedition. During this mission, and later on his own, Rugendas dedicated himself to documenting Brazilian nature and culture (Fig. 44, A-B). Back in Europe in 1825, and with the enthusiastic support of his compatriot Alexander Von Humboldt, he published his monumental book Viagem pitoresca ao Brasil (= Picturesque journey to Brazil) in Paris. Rugendas later travelled to Haiti and Mexico, 1831, to Chile, Argentina, Uruguay, Peru and Bolivia in 1834-1844, and finally went back to Rio de Janeiro in 1845 .

During the first months of 1824, Langsdorff finally began to organize the prolonged expedition which he 

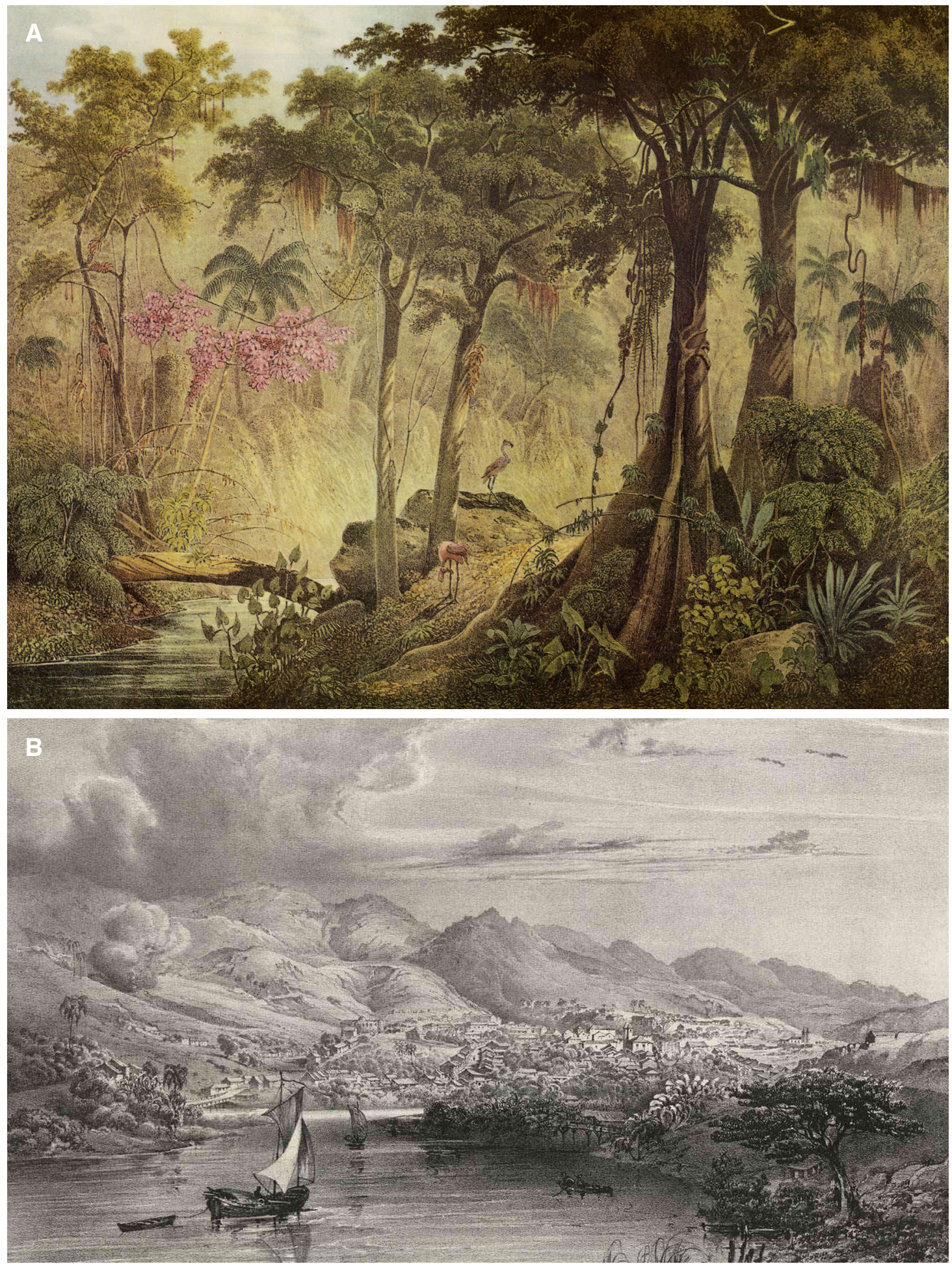

Figure 44. Engravings by Moritz Rugendas. A. Virgin forest at Manqueritipa (Rio de Janeiro). B. View of Sabará, Minas Gerais. 
had started planning four years before. On February 25th he applied for permission to undertake a scientific journey in the provinces of St. Paul, Minas Geraes, Goyaz, Matto Grosso and others, being always anxious to know more about the products of this wonderful country, the sole reason which leads him to undertake the difficult journey (Barman, 1971: 77). After further delays, the expedition, now including Riedel, started in early May.

Langsdorff's intention was to travel north across the Paraiba River into the mineral rich province of Minas Gerais, and then to turn west towards the provinces of Goais and Matto Grosso. However, after having explored the south and center of the province, it was decided to return to Rio. It seems that the direct route from Minas Gerais to Goais was unfrequented and undeveloped, difficult for a party so loaded with baggage. In addition, Moritz Rugendas and Edouard Ménétries refused to continue, due to personal difficulties with Langsdorff. Rugendas left Brazil on May 21st 1825, for Paris. Ménétries returned to Russia, where the Academy of Sciences, honoring a promise made to Langsdorff in 1821, took him into its service in 1826 as curator of the entomological section of the Academy's museum (Barman, 1971: 78). Thus, needing to find replacements, the expedition rested in Rio de Janeiro during the first half of 1825.

\section{Aimé-Adrien Taunay}

To fill the vacant positions, Langsdorff had now to draw upon such talent as was available in Rio de Janeiro. Christian Friedrich Hasse, a young Prussian about whom little is known, was chosen as the new zoologist. Rugendas was replaced by young AiméAdrien Taunay (1803-1828), son of the painter Nicolás-Antoine Taunay, who had arrived in Rio with the famous French Artistic Mission in 1816. Sadly, Taunay drowned on January 1st 1828, through his own imprudence, while trying to cross the Guaporé River on his horse.

\section{Antoine Hercules Florence}

After Taunay had been appointed as successor to Rugendas, Langsdorff thought of inviting a second artist to be paid from his own resources. Langsdorff was approached by another French artist, Antoine Hercules Florence (1802-1879) (Fig. 45), who replied

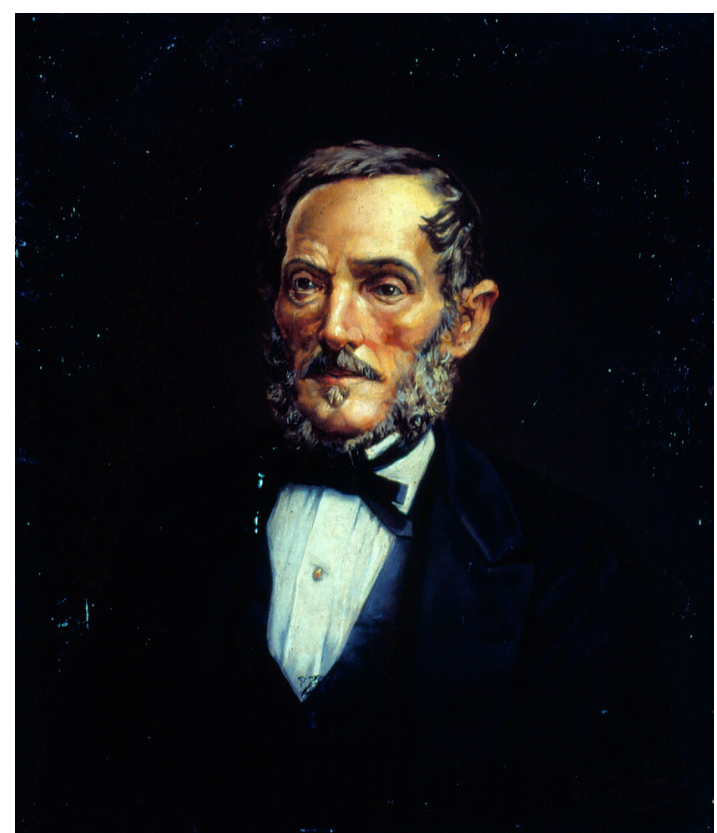

FIgURE 45. Antoine Hercules Florence (1804-1879). Portrait by Oscar Pereira da Silva.

to a newspaper advertisement. He was hired since he displayed a definite artistic talent. Florence would stay in Brazil for the rest of his life. He was the inventor of photography, six to eight years before Daguerre, Talbot and Niepce.

Langsdorff changed his original plans and instead of travelling directly overland from Rio de Janeiro to Goais, decided to adopt the suggestion of trustworthy persons that I would do better, in desiring to travel to Goyaz, to go by sea to the port of Santos where I will more easily find the means of transportation for my baggage (Barman, 1971: 79). Riedel and Hasse travelled to Sâo Paolo overland, while Langsdorff embarked in Rio for the port of Santos on August 29th 1825, and thence to Sâo Paolo.

Here began the main part of Langsdorff's Brazilian expedition. First came a period of research and preparation in the province of Sâo Paolo. Then, in June 1826, began the journey from Porto Feliz, by the Tietê River, to the city of Cuiabá, the capital of the province of Matto Grosso, where the party arrived in January 1827. The expedition stayed in Cuiabá for a total of ten months until November 1827, exploring and researching the environs of the city (Fig. 46).

The travellers then split into two groups: the first 


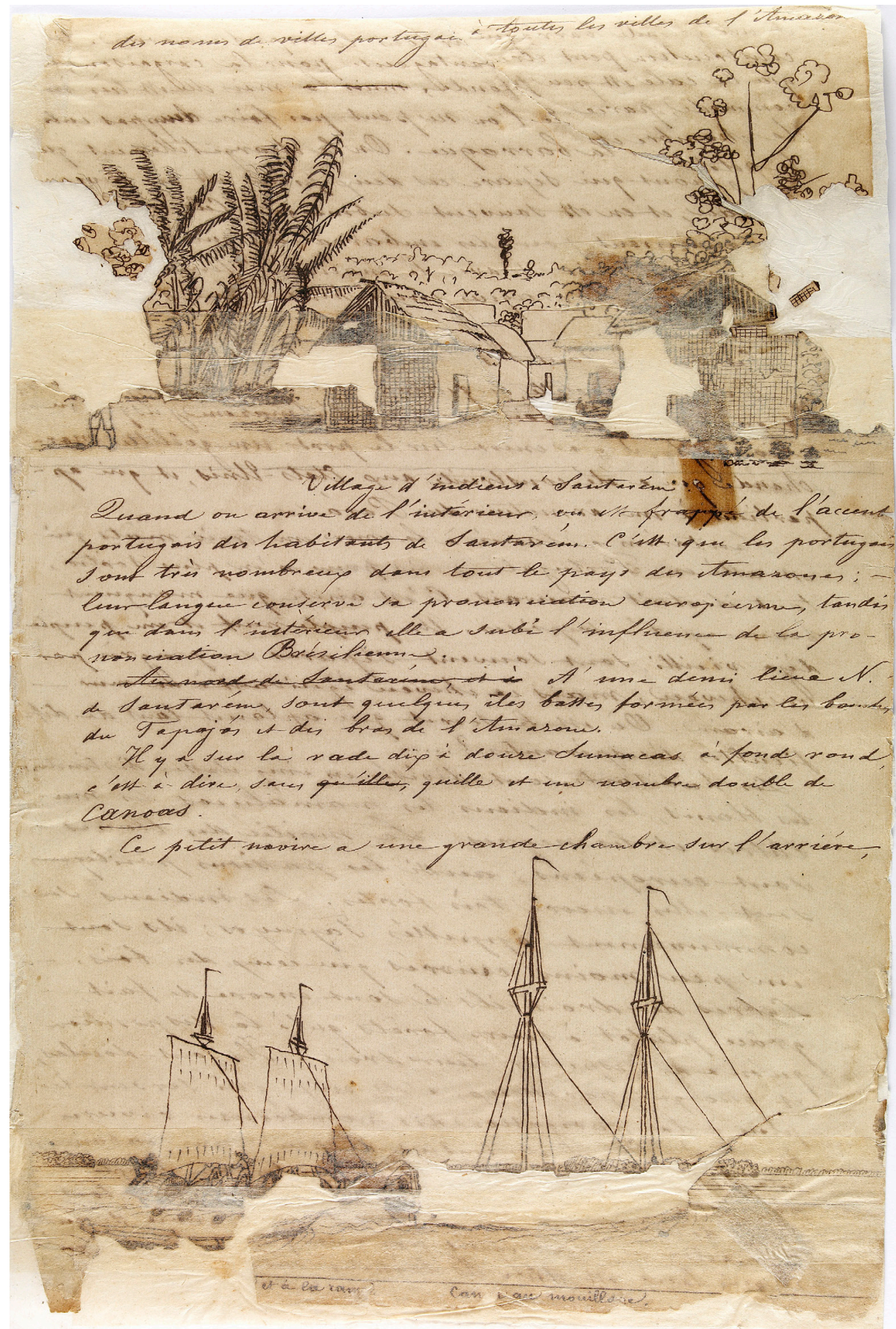

FiguRE 46. Indian village by Santarém. Hercules Florence. Page 410 of his manuscript. 


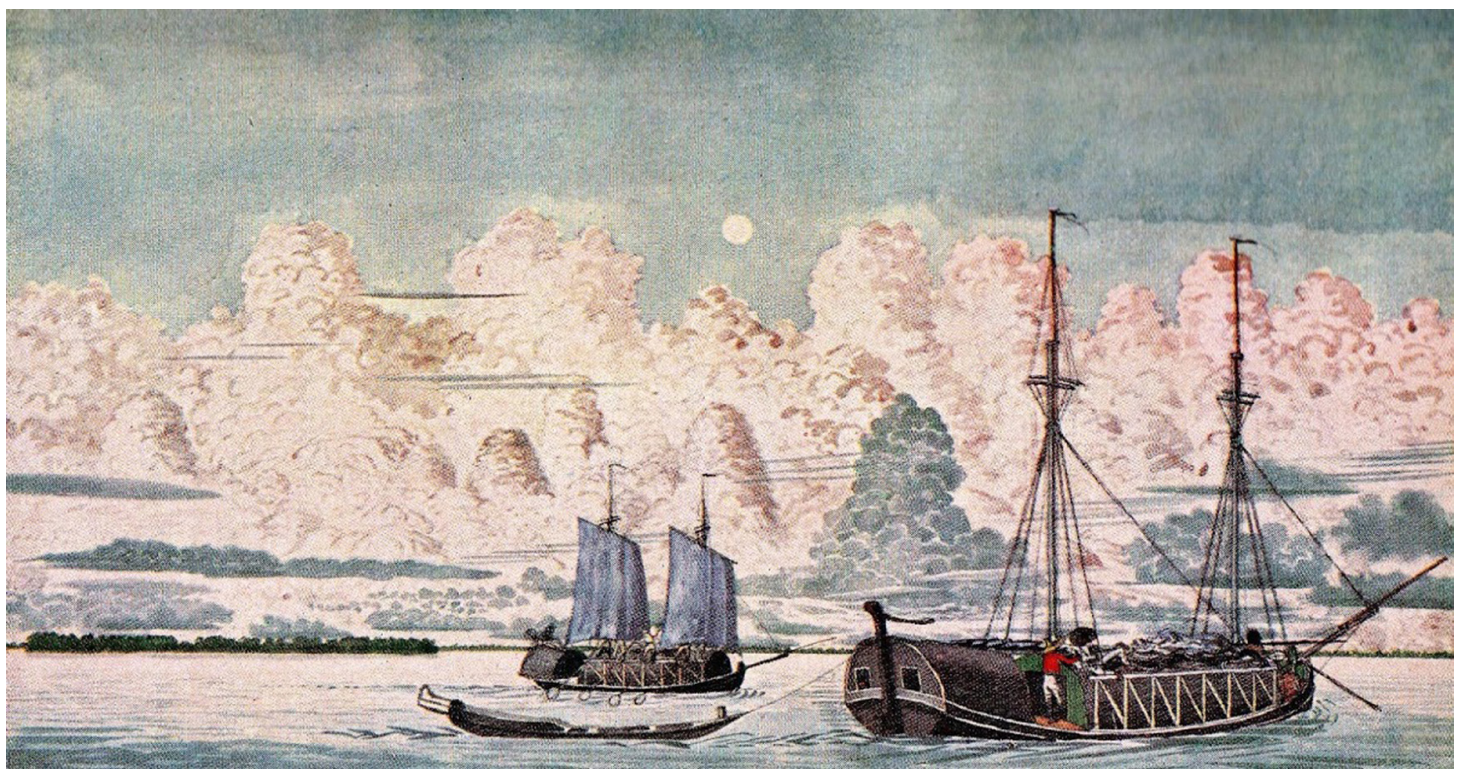

FiguRE 47. The Amazon as seen from Monte Alegre. Watercolor by Hercules Florence.

one, with Langsdorff, Rubtsov and Florence, set off northwards in December 1827 and managed to reach Santarém on the Amazon River (Fig. 47), despite enormous difficulties, on July 1st 1828 . Most of the members of the expedition became ill with tropical fevers (most probably malaria), including the Baron de Langsdorff. As a consequence of the febrile attacks, Langsdorff began to show signs of insanity and loss of memory at the Juruena River in May 1828. His condition deteriorated continuously. At the time, he wrote in his diary on May 13th, I was without memory and did not know and do not know anything about what took place (Barman, 1971: 89).

The second group, with Riedel and Taunay, took a north-westerly course along the Guaporé River, where Taunay drowned in January 1828. It then continued along the Mamoré and Madeira Rivers to Manaus. There Riedel received orders from the main party to continue to the port of Belem on the Atlantic, where the two groups finally rejoined in December 1828 . At last he arrived, wrote Florence after seeing Riedel again, being in his turn thin and wasted by the illnesses he suffered at the river Madeira where he underwent as much as we (Barman, 1971:89).

From Belem the expedition took ship to Rio de Janeiro, where they arrived in March 1829, almost four years and 6,000 kilometers after its departure.

\section{The orchids of the expedition}

The hardships of the expedition made it difficult for its members to collect many botanical and zoological specimens, or to make detailed descriptions of them. Most of the scientific results of Langsdorff's efforts were of geographic or ethnographic nature, being particularly interesting as they related to the many indigenous people of Brazil that they met. Today, a large part of the material has been recovered and is in the Ethnographic Museum, the Zoological Museum and in the Repositories of the Academy of Sciences of St. Petersburg. Therefore, it must be said that Langsdorff's contribution to Brazilian orchidology lies much more in his efforts to attract foreign travellers and botanists to Brazil than in his ill-fated expedition itself. However, we must mention here the few orchid specimens that were collected during the journey.

As collected by Langsdorff himself we find: Campylocentrum longicollis (Cogn.) Hoehne, C. latifolium Cogn., Gomesa barbaceniae (Lindl.) M.W.Chase \& N.H.Williams, Phymatidium lancifolium Lindl. (Fig. 48), and Habenaria santensis Kraenzl.

A much larger number of orchid specimens, collected by Riedel, can be found in the Natural History Museum in Paris. However, they correspond to collections that were made in the years after the expedition. Nevertheless, it was Langsdorff who first 


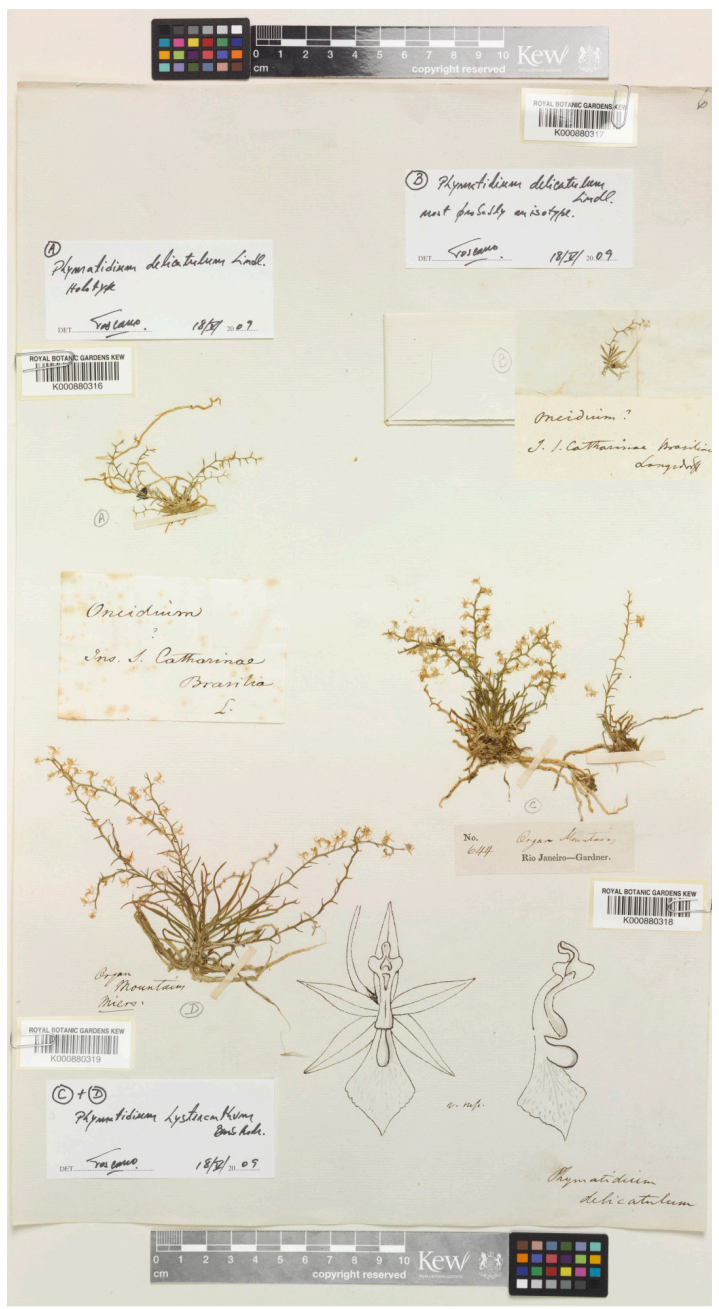

FiguRe 48. Phymatidium delicatulum Lindl. Specimen K000880317 in Herbarium Kew collected by Langsdorff.

brought Riedel to Brazil, so much of the credit must still go to him. These specimens are: Aspasia lunata Lindl., Encyclia patens Hook., Epidendrum tridactylum Lindl., Gomesa lietzei (Regel) M.W.Chase \& N.H. Williams, Habenaria riedelii Cogn. (Fig. 49), Ionopsis utricularioides (Sw.) Lindl., Lockhartia lunifera Rchb.f., Maxillaria cf. chlorantha Lindl., Maxillaria crocea Lindl., Miltonia flavescens Lindl., Mormolyca cf. rufescens (Lindl.) M.A.Blanco, Phymatidium lancifolium Lindl., Physurus longicornu Cogn., Rodriguezia pubescens Rchb.f., Stelis ruprechtiana Rchb.f. (Fig. 50), and Trichocentrum pumilum (Lindl.) M.W.Chase \& N.H.Williams,

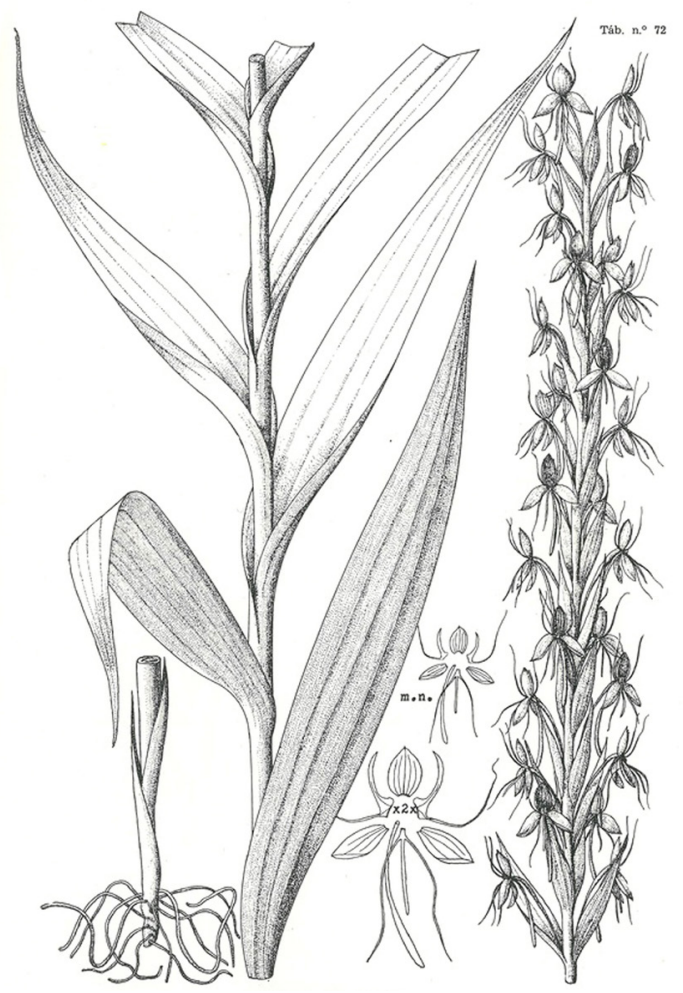

Figure 49. Habenaria riedelii Cogn. Illustration by F. C. Hoehne. Plate $\mathrm{N}^{\circ} 72$ of Flora Brasilica, 1940.

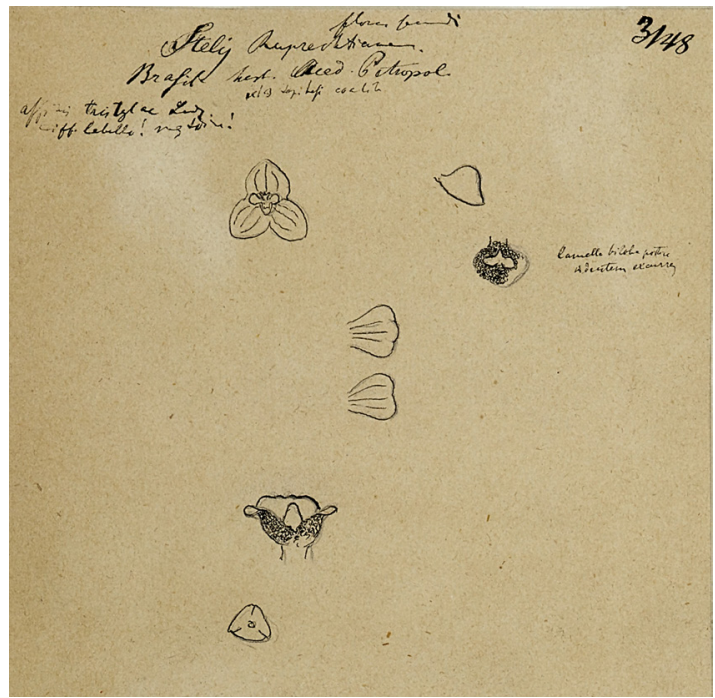

FIGURE 50. Stelis ruprechtiana, collected by Riedel. Flower analysis by Reichenbach in Vienna.

Finally, from Hercules Florence we have two beautiful water-colors of orchid species, a species of Cattleya, and one of Rodriguezia (Fig. 51-52). 


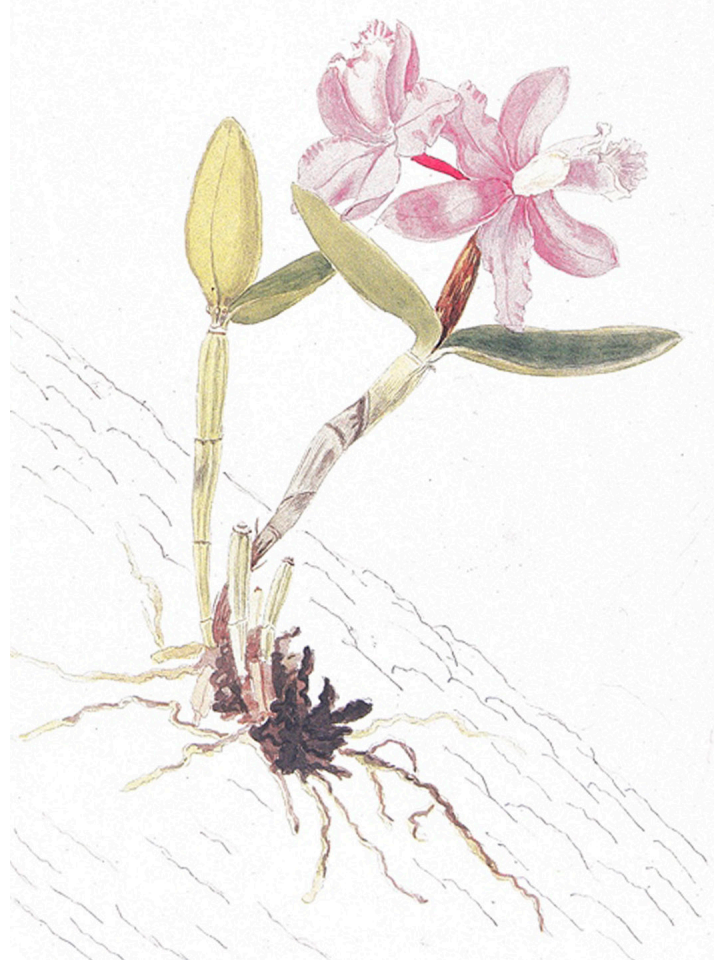

Figure 51. Cattleya loddigesii. Watercolor by Hercules Florence.

\section{Epilogue}

Without Langsdorff's guidance, the expedition slowly withered away. Rubtsov was the first to depart for Russia, taking part of the expedition's records, which were then kept at the Ministry of Marine. He later produced several maps of the expedition's route.

Hercules Florence stayed in Brazil for the rest of his life. Florence left the 84-page manuscript of his diary of the expedition with Félix Taunay (17951881), the brother of his unfortunate companion Adrien. The manuscript was translated into Portuguese and published by Félix's son, the historian Alfredo D'Escragnolle Taunay, more than forty years later, in 1875. It was the first publication about Langsdorff's unfortunate expedition.

Riedel took a break in St. Petersburg from 18301831, where he was handsomely rewarded for his work. The Botanical Garden of St. Petersburg paid 25,000 roubles for his botanical collection and another 12,000 for his herbarium, and also contracted with him, on February 14th 1831, for his return to Brazil, to make further collections of living plants. Riedel

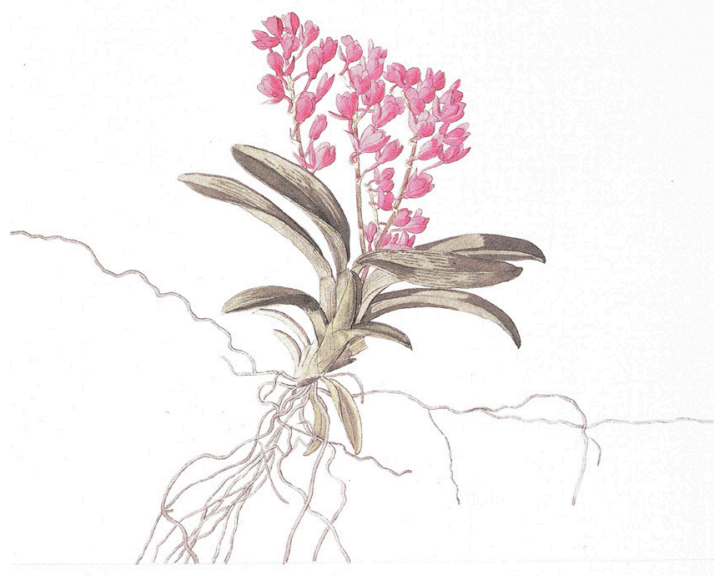

FIgURE 52. Rodriguezia lanceolata. Watercolor by Hercules Florence.

returned to Rio de Janeiro in August 1831, with orders to continue in Brazil the researches on natural history that M. de Langsdorff began (Barman, 1971: 91). In 1836 he accepted a permanent position at the National Museum in Rio, founding its department of botany and botanic garden. He continued to collect plants, during 1838-1839, accompanying the French botanist J.B.A. Guillemin, who had come to study tea cultivation. In addition, Ludwig Riedel played an important role in the collection of material for the Flora Brasiliensis, Carl Friedrich von Martius' magisterial work on Brazilian botany, which ran to fifty volumes before it was completed in the twentieth century.

The genera Riedelia C.F. Meisner in the Ericaceae and Riedeliella Harms in the Fabaceae are both named in his honour.

Langsdorff arrived in Rio in a state of complete irrationality. Ludwig Riedel and Peter Kielchen, the Russian Vice-consul, took control of the expedition and began to settle existing commitments, while awaiting orders from the Russian government. Langsdorff finally left Rio de Janeiro on April 17th 1830, in the care of a German friend, bound for the German town of Freiburg in Breisgau, where he spent the rest of his life. Behind him were seventeen years of life in Brazil. The 


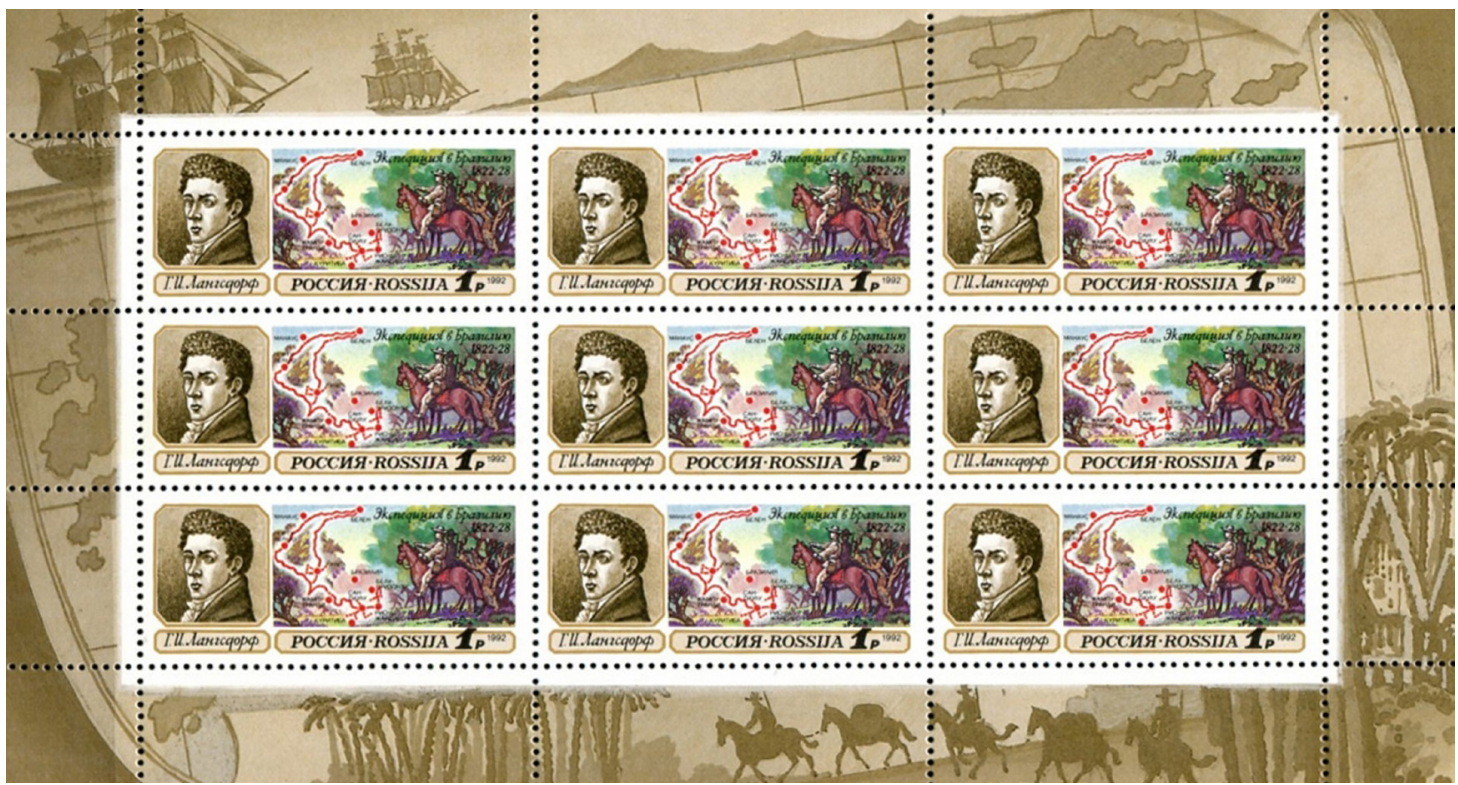

FIGURE 53. Russian postal stamp of 1992, commemorating Langsdorff's expedition.

Russian government granted him an annual pension of 11,000 francs. Langsdorff published nothing on the expedition in the twenty years between his retirement and his death (Fig. 53).
Aknowledgements. The author wishes to thank -once more- two friends who have become essential to all his writings: Rudolf Jenny and his inexhaustible supply on valuable information and friendly advice on orchid history, and Mark Budworth, whose meticulous philological review of the text is responsible for a - hopefully - agreeable reading of this article.

\section{LiTERATURE CITED}

Anonymous. (1846-1847). Exploring naturalists - II. Literary Record and Journal of the Linnean Association of Pennsylvania College, 2, 131-134.

Baldini, R. M. \& Guglielmone, L. (2012). Historical botanical collections in Latin America: the Italian contribution in the XIX century. Webbia, 67(1), 3-22.

Baldini, R. M. \& Pignotti, L. (2018). Giuseppe Raddi (17701829): an Italian and Florentine naturalist, pioneer on Brazilian territory, his contribution to the knowledge of the Neotropical Flora and his legacy to the biodiversity of the third millennium. Webbia, 73(1), 111-129. Doi: htts://doi.org/ 10.1080/00837792.2018.1444463

Banco do Brasil. (2010). Expediçâo Langsdorff. Catalogue of the exhibition.

Barman, R. J. (1971). The Forgotten Journey: Georg Heinrich Langsdorff and the Russian Imperial Scientific Expedition to Brazil, 1821-1829. Terrae Incognitae, 3(1), 67-96.

de Freycinet, M. L. (1826). Voyage autour du monde... exécuté sur les corvettes de S. M. l'Uranie et la Physicienne, pendant les années 1817, 1818, 1819 et 1820. París: Chez Pillet Aîné.

Herter, G. (1945). Auf den Spuren der Naturforscher Sellow und Saint-Hilaire. Stuttgart, Germany: E. Schweizerbart'sche Verlagsbuchhandlung.

Jenny, R. (2015). ...of men and orchids... (Part 1). Quito, Ecuador: Imprenta Mariscal.

Komissarov, B. (1994). Expedição Langsdorff: acervo e fontes históricas (Trad. Marcos Pinto Braga). São Paulo/Brasília: Ed. da Unesp.

Lack, H. W. (1983). Link \& Ottos 'Icones Plantarum Selectarum'. Zandera, 2(1-2), 2-21.

Link, H. F. \& Otto, F. (1820-1828). Icones plantarum selectarum Horti Regii Botanici Berolinensis cum descriptionibus et colendi ratione. Berlin: Decker.

Miles, M. J. (1996). Johann Moritz Rugendas. In: B. A. Tenenbaum \& G. M. Dorn (Eds.), Encyclopedia of Latin American History and Culture, vol. 4 (p. 619). 
New York: Charles Scribner's Sons.

Moro, J. (2012). El Imperio eres tú. Barcelona, España: Editorial Planeta S.A.

Peixoto Fonseca, D. (2008). O Viajante Hercules Florence, águas, guanás e guaranás. Brasil: Pontes Editores.

Pohl, J. B. E. (1832-1837). Reise im Innern von Brasilien. Germany: Wien.

Rodrigues de Moraes, P. L. (2009). The Brazilian Herbarium of Maximilian, Prince of Wied. Neodiversity, 4, 16-51.

Rodrigues de Moraes, P. L. (2012). The Lauraceae collected in Brazil by Ludwig Riedel - I. Harvard Papers in Botany, 17 (1), 185-216.

Rodrigues de Moraes, P. L., De Smedt, S. \& Hjertson, M. (2014). Notes on the Brazilian plants collected by Georg Wilhelm Freyreiss and published by Carl Peter Thunberg in Plantarum Brasiliensium. Harvard Papers in Botany, 19 (1), 123-132.

Rugendas, J. M. (1835). Malerische Reise in Brasilien. Paris, France: Engelmann \& Cie.

Sagredo Baeza, R. (2012). Science and Passion in America. Culture and History Digital Journal, 1(2), 1-19. Doi: http://dx.doi.org/10.3989/chdj.2012.m103

Strauss, D. (2012). Der Grüne Baron. Frankfurt: Peter Lang Verlag.

Swainson, J. W. (1840). Taxidermy: bibliography and biography. London: Longman, Orme, Brown, Green \&
Longmans.

Teixera Leite, J. R. (1988). Dicionário crítico da pintura no Brasil. Rio de Janeiro, Brasil: Artlivre.

von Spix, J. B. \& von Martius, C. F. P. (1824-1831). Travels in Brazil in the years 1817-1820, undertaken by command of His Majesty, the King of Bavaria. Three volumes and one Reiseatlas of illustrations. London: Longman, Hurst, Rees, Orme, Brown and Green.

Wagner, R. (1994). Thomas Ender in Brasilien. Graz, Austria: Akademische Druck-u. Verlagsanstalt.

Wied-Neuwied, M. A. P. (1820). Reise nach Brasilien in 1815 bis 1817 . Frankfurt: H. L. Brönner.

Wied-Neuwied, M. A. P. (1823-1825). Beitrag zur Flora Brasiliens. Nova acta academiae naturae curiosorum Akademie der Naturforscher Halle (Nova acta Leopoldina), 11, 1-88.

Wied-Neuwied, M. A. P. (1823-1825). Beitrag zur Flora Brasiliens. Nova acta academiae naturae curiosorum Akademie der Naturforscher Halle (Nova acta Leopoldina), 12, 1-54.

zu Wied, K. V. (1954). Maximilian Prinz zu Wied: Sein Leben und seine Reise. In: J. Roder \& H, Trimborn (Eds.), Maximilian Prinz zu Wied. Unveroffentliche Bilder und Handschriften zur Volkerkunde Brasiliens (pp. 13-25). Stuttgart, Germany: F. Dummler, Bonn, Hannover. 
